Supporting Information

\title{
Realizing Metal-Free Carbene-Catalyzed Carbonylation Reaction with CO
}

Jesse L. Peltier, ${ }^{a}$ Eder Tomás-Mendivil, a,b Daniel Tolentino, ${ }^{a}$ Max M. Hansmann, ${ }^{a}$ Rodolphe Jazzar, ${ }^{a}$ Guy Bertrand ${ }^{\star, a}$

aUCSD-CNRS Joint Research Chemistry Laboratory (UMI 3555), Department of Chemistry and Biochemistry, University of California San Diego, La Jolla, California 92093-0358, United States of America.

bDepartment of Applied Chemistry, Faculty of Chemistry, University of the Basque Country (UPV-EHU), Donostia-San Sebastián, 20018 Gipuzkoa, Spain.

Correspondence to: gbertrand@ucsd.edu 


\section{TABLE OF CONTENTS}

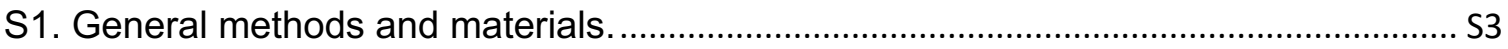

S2. Experimental procedures and characterization data................................................. S3

S2.1. Reaction of BiCAAC with carbon monoxide to afford Ket-1 ................................... S3

S2.2. Reaction of CAAC with carbon monoxide to afford Ket-2 .................................... S4

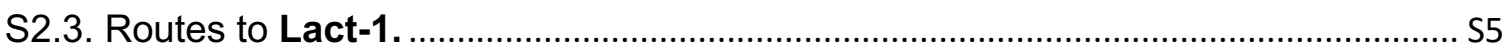

S2.3.1. Route A: Reaction of Ket-1 with Quin to afford Lact-1 ....................................... S5

S2.3.2. Route B: Reaction of BiCAAC with Carbo-1 to afford Lact-1 .............................. S5

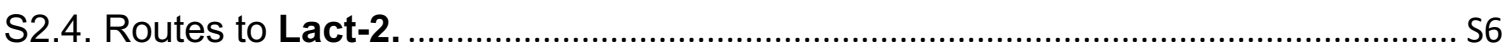

S2.4.1. Route A: Reaction of Ket-2 with Quin to afford Lact-2 ......................................... S6

S2.4.2. Route B: Reaction of CAAC with Quin in the presence of CO to afford Lact-2... S7

S2.4.3. Route C: Reaction of CAAC with Carbo-1 to afford Lact-2.................................S7

S2.4.4. Route D: Reaction of Ket-2 with Carbo-1 to afford Lact-2 ................................. S7

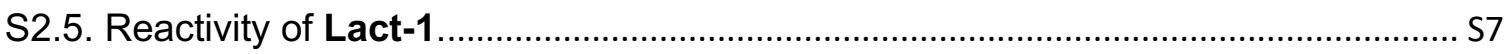

S2.5.1. Route A: Attempt at reductive elimination from Lact-1 at high temperature........S7

S2.5.2. Route B: Enforcing reductive elimination from Lact-1 in the presence of $S_{8} \ldots \ldots . . .8$

S2.5.3. Route C: Enforcing reductive elimination from Lact-1 in the presence of $\mathrm{CO}_{(\mathrm{g})}$. $\mathrm{S} 8$

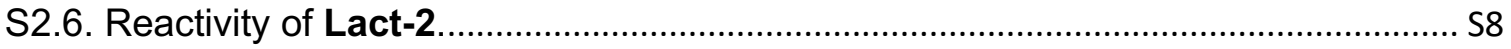

S2.6.1. Route A: Enforcing reductive elimination from Lact-2 in the presence of $S_{8} \ldots . . . S 8$

S2.6.2. Route B: Enforcing reductive elimination from Lact-2 in the presence of $\mathrm{CO}_{(\mathrm{g})}$. . s9

S2.7. Ethylene carbonate: enabling the observation of a kinetic vs a thermodynamic

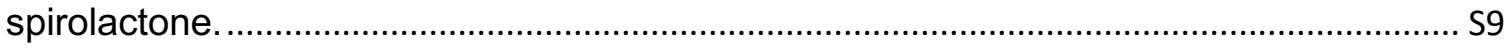

S2.7.1. Isomerization between the kinetic product, Lact-3', and the thermodynamic

product, Lact-3, after elevated temperatures.............................................................. S10

S2.7.2. Trapping the free BiCAAC by reductively eliminating Carbo-2 from Lact-3/Lact-3'

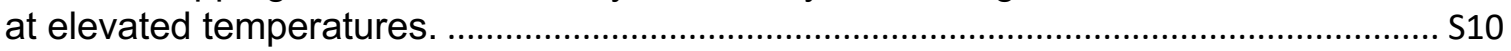

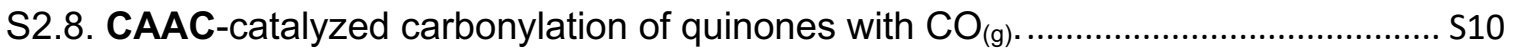

S2.8.1. Optimization: Procedure A for Table S1 ........................................................ S10

S2.8.2. Optimization: Procedure B for Table S1 .......................................................... S11

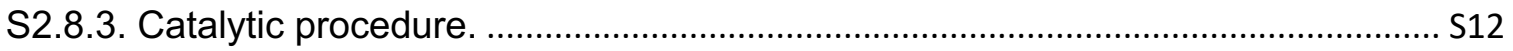

S2.8.4. Catalysis: Quin, CO, and CAAC catalyst afford Carbo-1 .................................. S12

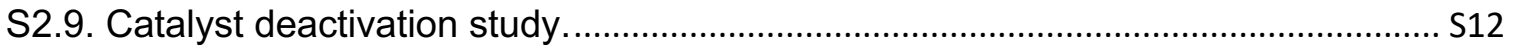

S2.9.1. Control experiment: reaction between CAAC and Quin. .................................. S12

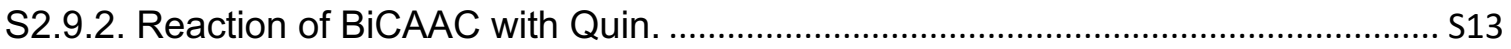

S2.9.3. Control experiment between CAAC ${ }^{\mathrm{Me}}$ and Quin. ............................................ S13

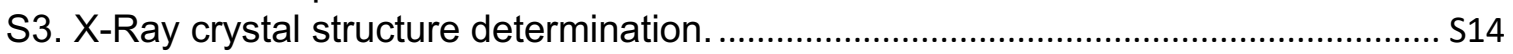

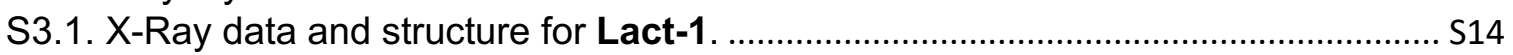

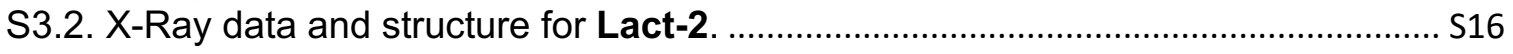

S3.3. X-Ray data and structure for Carbo-1 ................................................................ S18

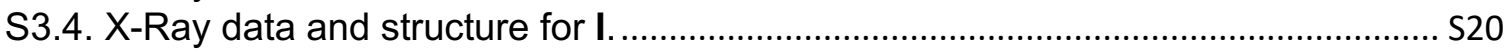

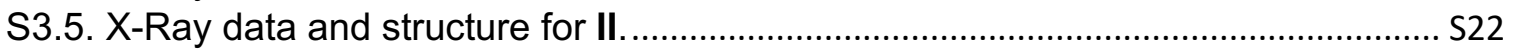

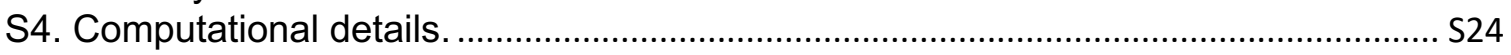

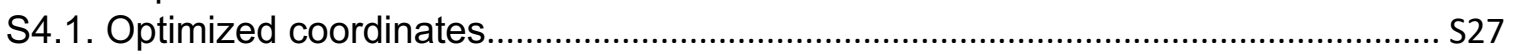

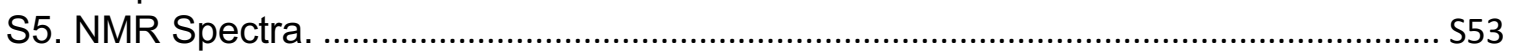

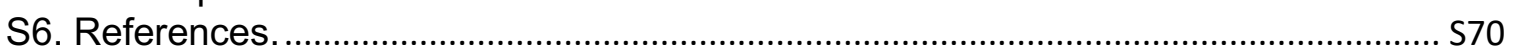




\section{S1. General methods and materials.}

All manipulations were performed-unless otherwise noted-under an atmosphere of dry argon using standard Schlenk or dry box techniques. Solvents were dried by standard methods and distilled under argon. ${ }^{1} \mathrm{H},{ }^{13} \mathrm{C}$ NMR spectra were recorded on a Varian VX 500, Bruker 300 , and Jeol 500 spectrometer. Chemical shifts are given in ppm and are referenced to $\mathrm{SiMe}_{4}\left({ }^{1} \mathrm{H},{ }^{13} \mathrm{C}\right)$. Coupling constants $J$ are given in Hertz as positive values regardless of their real individual signs. NMR multiplicities are abbreviated as follows: $s=$ singlet, $d=$ doublet, $t=$ triplet, $q=$ quartet, sept $=$ septet, $\mathrm{m}=$ multiplet, $\mathrm{br}=$ broad signal. All spectra were obtained at $25^{\circ} \mathrm{C}$ in the solvent indicated. For all neat or solid-state samples, FTIR spectra were collected on thin-film samples using a JASCO FTIR-4100 fitted with an ATR accessory (ZnSe plate). Solution phase FTIR spectra were recorded on a Thermo-Nicolet iS10 FTIR spectrometer. Samples were prepared as solutions with the corresponding solvent and injected into a ThermoFisher solution cell equipped with $\mathrm{KBr}$ windows. Solvent peaks were digitally subtracted from all solution FTIR spectra by comparison with an authentic solvent spectrum obtained prior to that of the sample. The intensities of the selected peaks are abbreviated as follows: $s=$ strong, $m=$ medium, $w=$ weak, $\mathrm{br}=$ broad. UV-Vis spectra were recorded on a Shimadzu UV-3600 UV/vis/NIR spectrometer, and samples were prepared as solutions under argon and transferred to an airtight cuvette $(I=1.0 \mathrm{~mm})$. The Mass spectra were performed at the UC San Diego Mass Spectrometry Laboratory on an Agilent 6230 Accurate-Mass TOFMS spectrometer. Single crystal X-ray diffraction data were collected on Bruker Apex diffractometers at the UC San Diego Crystallography Facility. BiCAAC, ${ }^{1}$ CAAC, ${ }^{2}$ and CAAC ${ }^{\text {Me }},{ }^{3}$ were prepared as reported in the literature, while all other starting materials were purchased from commercial sources and used without further purification.

\section{S2. Experimental procedures and characterization data.}

S2.1. Reaction of BiCAAC with carbon monoxide to afford Ket-1.

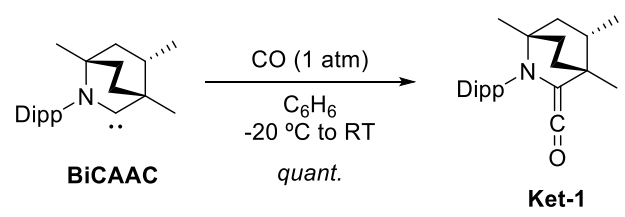

Fig. S1. Synthesis of amino ketene Ket-2 from BiCAAC and $\mathrm{CO}_{(\mathrm{g})}$.

In a pressure Schlenk (or Young NMR tube for small scale reaction) free BiCAAC $(0.100 \mathrm{~g}$, $0.32 \mathrm{mmol}$ for preparative scale; $0.030 \mathrm{~g}, 0.096 \mathrm{mmol}$ in Young NMR tube) was dissolved in 3 $\mathrm{mL}$ of dry benzene or $0.7 \mathrm{~mL}$ of dry deuterated benzene, respectively, under argon atmosphere. The solution was cooled down to $-20{ }^{\circ} \mathrm{C}$ until the solvent froze and it was degassed under vacuum. Carbon monoxide was introduced into the flask and it was warmed to room temperature. The solution immediately turned blue when benzene melted $\left(5^{\circ} \mathrm{C}\right.$; see Fig. S2). The degasification/CO gas introduction process was repeated three times until the solution was deep blue. The conversion to Ket-1 was quantitative and clean. In order to isolate the product as blue crystalline solid, volatiles were removed under vacuum and minimum amount of dry pentane was added $(1 \mathrm{~mL})$. Upon storing the solution in the freezer $\left(-40{ }^{\circ} \mathrm{C}\right)$ under inert atmosphere (Argon filled glovebox), blue crystals appeared which were decanted and dried. Yield $85 \%$ (0.092 $\mathrm{g}$ for preparative scale). (The reaction is instantaneous at $R T$ and CO bubbling is neither needed nor recommended to avoid undesired side-products). Characterization data: IR $(20 \mathrm{mg} / \mathrm{mL}$ in pentane $): \mathrm{v}_{\text {(CO stretching })}=2080 \mathrm{~cm}^{-1} ;$ UV-vis. $(20 \mathrm{mg} / \mathrm{mL}$ in pentane): broad band from 500 to $700 \mathrm{~nm}\left(\lambda_{\max } 580 \mathrm{~nm}\right) ;{ }^{1} \mathrm{H}$ NMR $\left(500 \mathrm{MHz}, \mathrm{C}_{6} \mathrm{D}_{6}\right): \delta=7.14-$ $7.08(\mathrm{~m}, 1 \mathrm{H}), 7.05-7.01(\mathrm{~m}, 2 \mathrm{H}), 3.71$ (sept, $J=6.9 \mathrm{~Hz}, 1 \mathrm{H}), 3.60$ (sept, $J=6.9 \mathrm{~Hz}, 1 \mathrm{H}), 2.10-$ $1.99(\mathrm{~m}, 2 \mathrm{H}), 1.71-1.59(\mathrm{~m}, 4 \mathrm{H}), 1.46-1.40(\mathrm{~m}, 1 \mathrm{H}), 1.31(\mathrm{~d}, J=6.9 \mathrm{~Hz}, 3 \mathrm{H}), 1.28-1.23(\mathrm{~m}, 9 \mathrm{H})$, $1.09(\mathrm{~d}, J=6.5 \mathrm{~Hz}, 3 \mathrm{H}), 0.74(\mathrm{~s}, 3 \mathrm{H}), 0.69(\mathrm{~s}, 3 \mathrm{H}), \mathrm{ppm} ;{ }^{13} \mathrm{C}\left\{{ }^{1} \mathrm{H}\right\} \mathrm{NMR}\left(125.7 \mathrm{MHz}, \mathrm{C}_{6} \mathrm{D}_{6}\right): \delta=$ 
$270.7,150.8,150.7,138.4,128.3,124.6,124.2,78.7,52.4,46.5,37.2,36.4,35.5,33.6,28.9$, 28.6, 26.0, 25.3, 24.6, 24.2, 23.6, 21.0, $18.6 \mathrm{ppm}$.

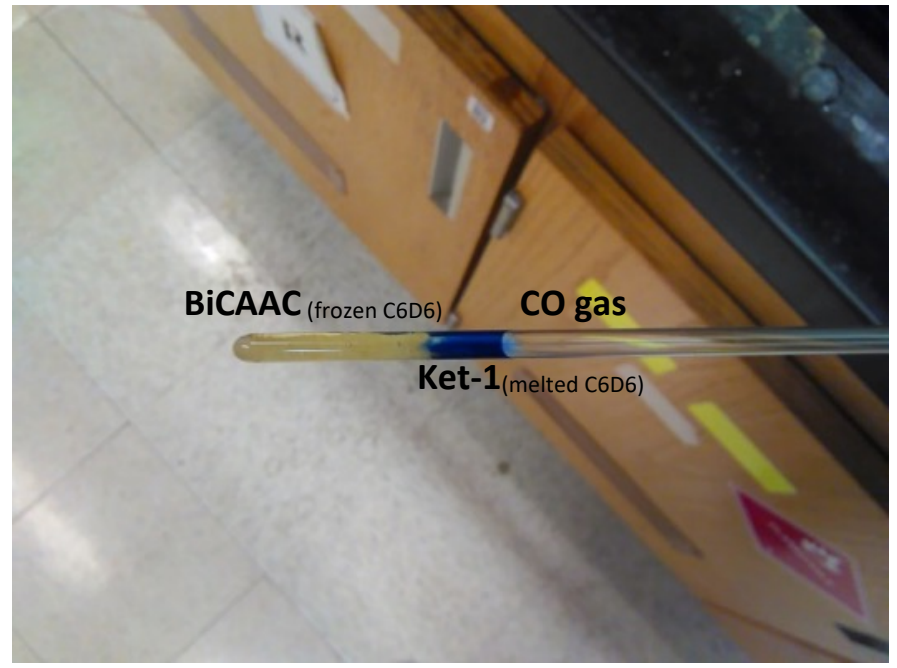

Fig. S2. Synthesis of amino ketene Ket-1 in a J. Young NMR tube. From left to right: BiCAAC in frozen $\mathrm{C}_{6} \mathrm{D}_{6}$ solution is colorless to pale yellow; upon melting the solution, Ket-1 is formed as evidenced by the deep blue color of the solution; and a $\mathrm{CO}_{(\mathrm{g})}$ atmosphere is in the headspace.

\section{S2.2. Reaction of CAAC with carbon monoxide to afford Ket-2.}
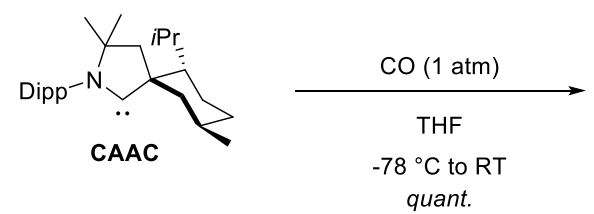

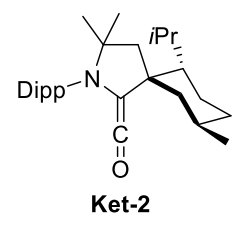

Ket-2

Fig. S3. Synthesis of known amino ketene Ket-2 from CAAC and $\mathrm{CO}_{(\mathrm{g})}$.

In a J. Young NMR tube, CAAC $(0.2 \mathrm{~g}, 0.524 \mathrm{mmol})$ was dissolved in $1 \mathrm{~mL}$ of dry THF under argon atmosphere. The solution was cooled down to $-78{ }^{\circ} \mathrm{C}$ and it was degassed under vacuum. Carbon monoxide (1 atm) was introduced into the tube and upon warming to room temperature, the solution turned blue. The degasification/CO gas introduction process was repeated three times until the solution was a deep blue. The conversion to the known Ket-2 ${ }^{4}$ was quantitative and clean in solution. Afterwards, to isolate the solid, volatiles were removed under vacuum at $0{ }^{\circ} \mathrm{C}$ and a minimum amount of dry pentane was added $(1 \mathrm{~mL})$. Upon storing the solution in the freezer $\left(-40^{\circ} \mathrm{C}\right.$ ) under an inert atmosphere (Argon filled glovebox) blue crystals appeared, which were decanted and dried. Yield $90 \%$ (0.193 $\mathrm{g}$ for preparative scale). Characterization data: ${ }^{1} \mathrm{H}$ NMR $\left(500 \mathrm{MHz}, \mathrm{THF}-\mathrm{d}_{8}\right): \delta=7.26-7.10(\mathrm{~m}, 3 \mathrm{H}), 3.65$ (sept, $J=6.8$, 1H), 3.57 (sept, $J=6.8,1 \mathrm{H}$ ), $2.59(\mathrm{dt}, J=12.6,2.3 \mathrm{~Hz}, 1 \mathrm{H}), 2.55(\mathrm{~d}, J=13.1 \mathrm{~Hz}, 1 \mathrm{H}), 2.39$ (sept, $J=6.8 \mathrm{~Hz}, 1 \mathrm{H}), 1.85(\mathrm{~d}, J=13.1 \mathrm{~Hz}, 1 \mathrm{H}), 1.65-1.62(\mathrm{~m}, 1 \mathrm{H}), 1.57-1.53(\mathrm{~m}, 1 \mathrm{H}), 1.39-1.34$ $(\mathrm{m}, 2 \mathrm{H}), 1.31-1.24(\mathrm{~m}, 13 \mathrm{H}), 1.07(\mathrm{~d}, J=6.8 \mathrm{~Hz}, 3 \mathrm{H}), 1.02(\mathrm{~d}, J=6.8 \mathrm{~Hz}, 1 \mathrm{H}), 1.00(\mathrm{~d}, J=6.8$ $\mathrm{Hz}, 3 \mathrm{H}), 0.90(\mathrm{~d}, J=6.6 \mathrm{~Hz}, 3 \mathrm{H}), 0.87-0.79(\mathrm{~m}, 2 \mathrm{H}) \mathrm{ppm} ;{ }^{13} \mathrm{C}\left\{{ }^{1} \mathrm{H}\right\} \mathrm{NMR}\left(125.7 \mathrm{MHz}, \mathrm{THF}-\mathrm{d}_{8}\right): \delta$ $=278.8,152.3,152.1,134.7,128.8,125.0,124.8,81.6,64.9,55.2,53.9,50.1,50.0,35.5,31.4$, $31.3,30.6,29.3,29.2,28.5,26.9,26.2,23.9,23.6,22.8,18.5$ ppm. 
S2.3. Routes to Lact-1.

A.

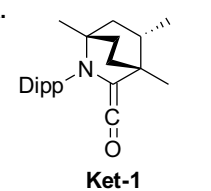<smiles>O=C1C(=O)c2ccccc2-c2ccccc21</smiles><smiles>C1CCCCC1</smiles><smiles>CC1=CC2(C)CC1(C)N(c1ccccc1)C2(C)C(C)(C)Br</smiles><smiles></smiles>

$\mathrm{C}_{6} \mathrm{D}_{6}, \mathrm{RT}$

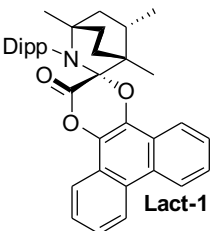

Fig. S4. Synthetic routes to Lact-1; A. Ket-1 can react with an o-quinone, Quin; B. BiCAAC can react with Carbo-1 thereby showing the reversibility of reductive elimination.

\section{S2.3.1. Route A: Reaction of Ket-1 with Quin to afford Lact-1.}

In a Young NMR tube free BiCAAC $(0.030 \mathrm{~g}, 0.096 \mathrm{mmol})$ was dissolved in $0.7 \mathrm{~mL}$ of dry deuterated benzene under an argon atmosphere. The solution was cooled down to $-20{ }^{\circ} \mathrm{C}$ until the solvent froze and it was degassed under vacuum. Carbon monoxide was introduced into the flask and the flask was warmed to room temperature. The solution immediately turned blue when the benzene melted (see protocol for the amino ketene Ket-1). The degasification/CO gas introduction process was repeated three times until the solution was deep blue. The tube was introduced into a glovebox filled with dry Argon and opened to exchange the $\mathrm{CO}$ atmosphere with Argon. Then, the corresponding 9,10-phenanthrenequinone (Quin; $0.096 \mathrm{mmol}$ ) was introduced and the solution immediately turned dark green-orange with some dark precipitate in suspension. NMR analysis showed clean and quantitative formation of the corresponding adduct Lact-1. Crystallization of Lact-1: In a Teflon sealed pressure Schlenk, free BiCAAC $(0.030 \mathrm{~g}, 0.096 \mathrm{mmol})$ was dissolved in $1 \mathrm{~mL}$ of dry $\mathrm{Et}_{2} \mathrm{O}$ under argon atmosphere. At room temperature, carbon monoxide was introduced in the flask (no bubbling, just replacement of the atmosphere). The solution immediately turned blue. The solution was stirred for 15 minutes, until it turned deep blue. The flask was sealed and introduced in a glovebox filled with dry Argon and opened to exchange the $\mathrm{CO}$ atmosphere with Argon. Then, 9,10-phenanthrenequinone (Quin; $0.020 \mathrm{~g}, 0.096 \mathrm{mmol}$ ) was added and the solution immediately turned dark green. After 15 minutes stirring at room temperature, some black precipitate formed, and it was removed by filtration. The clear greenish solution was sealed and stored in a freezer at $-40{ }^{\circ} \mathrm{C}$ until yellow crystals grew for X-ray analysis. Yield $74 \%(0.036 \mathrm{~g})$. Characterization data: ${ }^{1} \mathrm{H}$ NMR (500 $\left.\mathrm{MHz}, \mathrm{C}_{6} \mathrm{D}_{6}\right): \delta=8.51(\mathrm{~d}, J=8.1 \mathrm{~Hz}, 1 \mathrm{H}), 8.28(\mathrm{~d}, J=8.3 \mathrm{~Hz}, 1 \mathrm{H}), 8.23-8.16(\mathrm{~m}, 1 \mathrm{H}), 7.97-7.91$ $(\mathrm{m}, 1 \mathrm{H}), 7.46(\mathrm{t}, J=7.3 \mathrm{~Hz}, 1 \mathrm{H}), 7.31(\mathrm{t}, J=7.3 \mathrm{~Hz}, 1 \mathrm{H}), 7.19-7.11(\mathrm{~m}, 3 \mathrm{H}), 6.97(\mathrm{t}, J=7.7 \mathrm{~Hz}$, $1 \mathrm{H}), 6.80(\mathrm{~d}, J=7.7,1 \mathrm{H}), 4.18$ (sept, $J=6.6 \mathrm{~Hz}, 1 \mathrm{H}$ ), 3.99 (sept, $J=6.6 \mathrm{~Hz}, 1 \mathrm{H}), 2.93$ (dd, $J=$ 19.6, $11.6 \mathrm{~Hz}, 1 \mathrm{H}), 2.46(\mathrm{dd}, J=16.6,6.3 \mathrm{~Hz}, 1 \mathrm{H}), 2.08(\mathrm{t}, J=11.5 \mathrm{~Hz}, 1 \mathrm{H}), 1.82-1.76(\mathrm{~m}, 1 \mathrm{H})$, $1.75(\mathrm{~d}, J=6.4 \mathrm{~Hz}, 3 \mathrm{H}), 1.58-1.51(\mathrm{~m}, 2 \mathrm{H}), 1.44-1.08(\mathrm{~m}, 2 \mathrm{H}), 1.26(\mathrm{~d}, J=6.8 \mathrm{~Hz}, 3 \mathrm{H}), 1.23(\mathrm{~d}$, $J=7.1 \mathrm{~Hz}, 3 \mathrm{H}), 1.18(\mathrm{~d}, J=6.8 \mathrm{~Hz}, 3 \mathrm{H}), 0.91(\mathrm{~s}, 3 \mathrm{H}), 0.84(\mathrm{~s}, 3 \mathrm{H}), 0.55(\mathrm{~d}, J=6.6 \mathrm{~Hz}, 3 \mathrm{H})$ ppm; ${ }^{13} \mathrm{C}\left\{{ }^{1} \mathrm{H}\right\}$ NMR $\left(125.7 \mathrm{MHz}, \mathrm{C}_{6} \mathrm{D}_{6}\right): \delta=159.6,153.0,152.2,137.6,134.9,129.4,129.1$, $128.7,128.4,127.5,126.4,126.3,125.6,125.5,125.4,125.3,125.2,124.4,123.7,123.3$, 122.7, 120.4, 103.3, 55.4, 47.5, 44.0, 36.7, 34.8, 33.0, 29.6, 29.2, 27.0, 26.6, 26.2, 26.0, 25.2, 19.6, 18.3 ppm; HRMS (ESI): $\mathrm{m} / \mathrm{z}$ calculated for $\mathrm{C}_{37} \mathrm{H}_{42} \mathrm{NO}_{3}[\mathrm{M}+\mathrm{H}]^{+} 548.3159$; found 548.3155; X-ray see below.

\section{S2.3.2. Route B: Reaction of BiCAAC with Carbo-1 to afford Lact-1.}

To probe the nature of the equilibrium, BiCAAC $(0.050 \mathrm{~g}, 0.16 \mathrm{mmol})$ was dissolved in $0.7 \mathrm{~mL}$ of dry deuterated benzene under an argon atmosphere. Then, Carbo-1 $(0.038 \mathrm{~g}, 0.16 \mathrm{mmol})$ was added to the solution which immediately turned dark green. NMR analysis showed clean and quantitative formation of the corresponding adduct Lact-1. 
S2.4. Routes to Lact-2.

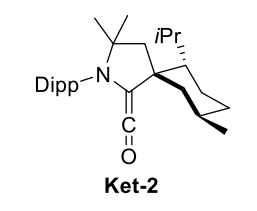

B.

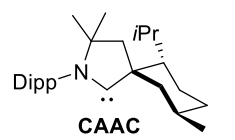<smiles>O=C1C(=O)c2ccccc2-c2ccccc21</smiles><smiles>CC[18OH]</smiles>

c.

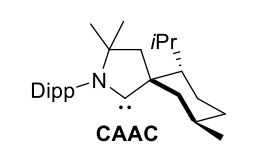

D.<smiles>CC1CCC2(C(C)C)CC(C(C(C)C)C1)C(C)(C)N(c1ccccc1)C2=C=O</smiles><smiles>O=C1C(=O)c2ccccc2-c2ccccc21</smiles>
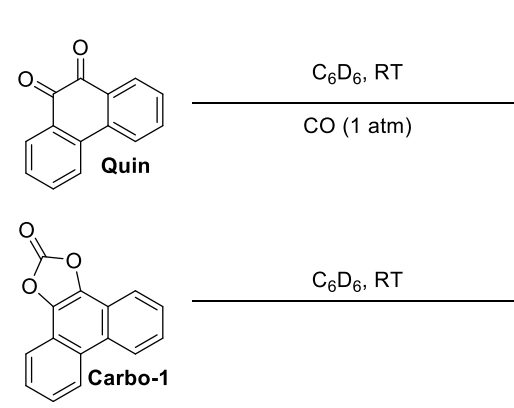

o<smiles></smiles>

$\mathrm{C}_{6} \mathrm{D}_{6}, 60^{\circ} \mathrm{C}$

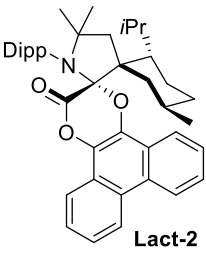

Fig. S5. Synthetic routes to Lact-2; A. Ket-2 reacts with Quin; B. Upon mixing CAAC and Quin, no reaction occurs until after $\mathrm{CO}_{(\mathrm{g})}$; C. Carbo-1 can directly add to CAAC demonstrating an equilibrium; D. An equilibrium exists at $60{ }^{\circ} \mathrm{C}$ as Ket-2 can release $\mathrm{CO}_{(\mathrm{g})}$ and add Carbo-1 when under argon.

\section{S2.4.1. Route A: Reaction of Ket-2 with Quin to afford Lact-2.}

In a J. Young NMR tube, free CAAC $(0.030 \mathrm{~g}, 0.079 \mathrm{mmol})$ was dissolved in $0.7 \mathrm{~mL}$ of dry deuterated benzene under an argon atmosphere. The solution was cooled down to $-20^{\circ} \mathrm{C}$ until the solvent froze, and it was degassed under vacuum. Carbon monoxide was introduced into the tube and it was warmed to room temperature. The solution immediately turned blue when the benzene melted. The degasification/CO gas introduction process was repeated three times until the solution was a deep blue. The tube was introduced into a glovebox filled with dry Argon and opened to exchange the $\mathrm{CO}$ atmosphere with Argon. Then, 1,9-phenanthrenequinone (Quin; $0.0164 \mathrm{~g}, 0.079 \mathrm{mmol}$ ) was introduced, the solution immediately turned yellowish-orange and then became colorless. NMR analysis showed clean and quantitative formation of a single diastereomer of the resulting carbonate adduct Lact-2. After volatiles were removed under vacuum, the solid was washed with $1 \mathrm{~mL}$ of pentane, and a white solid was isolated. Yield $97 \%$ $(0.047 \mathrm{~g})$. Crystallization of Lact-2: Crystals were grown overnight from a saturated benzene solution. Characterization data: ${ }^{1} \mathrm{H}$ NMR $\left(500 \mathrm{MHz}, \mathrm{C}_{6} \mathrm{D}_{6}\right): \delta=8.44(\mathrm{~d}, J=8.0 \mathrm{~Hz}, 1 \mathrm{H}), 8.34$ $(\mathrm{d}, J=8.3 \mathrm{~Hz}, 1 \mathrm{H}), 8.28(\mathrm{~d}, J=8.2 \mathrm{~Hz}, 1 \mathrm{H}), 8.10(\mathrm{~d}, J=8.0 \mathrm{~Hz}, 1 \mathrm{H}), 7.45(\mathrm{t}, J=7.5 \mathrm{~Hz}, 1 \mathrm{H})$, 7.36 (t, $J=7.7 \mathrm{~Hz}, 1 \mathrm{H}), 7.30$ (dd, $J=7.7,1.6 \mathrm{~Hz}, 1 \mathrm{H}), 7.26(\mathrm{t}, J=7.4 \mathrm{~Hz}, 1 \mathrm{H}), 7.23-7.19(\mathrm{~m}$, $1 \mathrm{H}), 7.12(\mathrm{t}, J=7.7 \mathrm{~Hz}, 1 \mathrm{H}), 6.97(\mathrm{dd}, J=7.6,1.4 \mathrm{~Hz}, 1 \mathrm{H}), 4.42(\mathrm{br}, 1 \mathrm{H}), 4.19$ (sept, $J=6.6 \mathrm{~Hz}$, $1 \mathrm{H}), 3.35(\mathrm{~d}, J=12.2 \mathrm{~Hz}, 1 \mathrm{H}), 2.98(\mathrm{br}, 1 \mathrm{H}), 2.63(\mathrm{br}, 1 \mathrm{H}), 2.15(\mathrm{tt}, J=11.0,5.5 \mathrm{~Hz}, 1 \mathrm{H}), 1.86$ $(\mathrm{d}, J=6.4 \mathrm{~Hz}, 3 \mathrm{H}), 1.75-1.67(\mathrm{~m}, 2 \mathrm{H}), 1.58(\mathrm{~s}, 3 \mathrm{H}), 1.42(\mathrm{~d}, J=6.6 \mathrm{~Hz}, 3 \mathrm{H}), 1.34(\mathrm{~s}, 3 \mathrm{H}), 1.38-$ $1.25(\mathrm{~m}, 5 \mathrm{H}), 1.14(\mathrm{~d}, J=6.6 \mathrm{~Hz}, 3 \mathrm{H}), 1.02(\mathrm{~d}, J=6.2 \mathrm{~Hz}, 3 \mathrm{H}), 0.70(\mathrm{br}, 5 \mathrm{H}), 0.31(\mathrm{~d}, J=6.2$ $\mathrm{Hz}, 3 \mathrm{H}),-0.23$ (br, 3H) ppm; ${ }^{13} \mathrm{C}\left\{{ }^{1} \mathrm{H}\right\}$ NMR $\left(125.7 \mathrm{MHz}, \mathrm{C}_{6} \mathrm{D}_{6}\right): \delta=159.7,154.6,151.7,135.1$, $133.9,129.2$, 128.4, 127.6, 127.2, 126.6, 126.5, 126.3, 126.2, 125.7, 125.5, 124.3, 123.4, 123.0, 121.4, 120.2, 104.3, 63.6, 62.4, 59.0, 51.8, 34.0, 30.7, 29.5, 29.4, 28.4, 26.9, 26.8, 26.6, 24.7, 23.6, 19.8 ppm; IR (neat): 2990 (m), 2952 (s), 2922 (s), 2865 (s), 1785 (s), $1661(\mathrm{~m}), \mathrm{cm}^{-1}$; HRMS (ESI): $\mathrm{m} / \mathrm{z}$ calculated for $\mathrm{C}_{42} \mathrm{H}_{52} \mathrm{NO}_{3}[\mathrm{M}+\mathrm{H}]^{+} 618.3942$; found 618.3934 ; $\mathbf{X}$-ray see below. 


\section{S2.4.2. Route B: Reaction of CAAC with Quin in the presence of CO to afford Lact-2.}

In a J. Young NMR tube, free CAAC $(0.030 \mathrm{~g}, 0.079 \mathrm{mmol})$ and 1,9-phenanthrenequinone (Quin; $0.0164 \mathrm{~g}, 0.079 \mathrm{mmol}$ ) were dissolved in $0.7 \mathrm{~mL}$ of dry deuterated benzene under an argon atmosphere. Then, the solution was cooled down to $-20^{\circ} \mathrm{C}$ until the solvent froze, and it was degassed under vacuum. The degasification/CO gas introduction process was repeated three times. NMR analysis showed clean and quantitative formation of a single diastereomer of the resulting carbonate adduct Lact-2.

\section{S2.4.3. Route C: Reaction of CAAC with Carbo-1 to afford Lact-2.}

In a J. Young NMR tube, free CAAC $(0.030 \mathrm{~g}, 0.079 \mathrm{mmol})$ and Quin $(0.0186 \mathrm{~g}, 0.079 \mathrm{mmol})$ were dissolved in $0.7 \mathrm{~mL}$ of dry deuterated benzene under an argon atmosphere. After 30 minutes, NMR analysis showed clean and quantitative formation of a single diastereomer of the carbonate adduct Lact-2.

\section{S2.4.4. Route D: Reaction of Ket-2 with Carbo-1 to afford Lact-2.}

In a J. Young NMR tube, free CAAC $(0.030 \mathrm{~g}, 0.079 \mathrm{mmol})$ was dissolved in $0.7 \mathrm{~mL}$ of dry deuterated benzene under an argon atmosphere. The solution was cooled down to $-20^{\circ} \mathrm{C}$ until the solvent froze, and it was degassed under vacuum. Carbon monoxide was introduced into the tube and it was warmed to room temperature. The solution immediately turned blue when the benzene melted. The degasification/CO gas introduction process was repeated three times until the solution was a deep blue. The tube was introduced into a glovebox filled with dry Argon and opened to exchange the CO atmosphere with Argon. Then, Quin $(0.0186 \mathrm{~g}, 0.079 \mathrm{mmol})$ was added to the blue solution. Upon sonication or heating the solution to $60{ }^{\circ} \mathrm{C}$ for 1 hour, the mixture became colorless. NMR analysis showed clean and quantitative formation of a single diastereomer of the carbonate adduct Lact-2.

\section{S2.5. Reactivity of Lact-1.}

A.

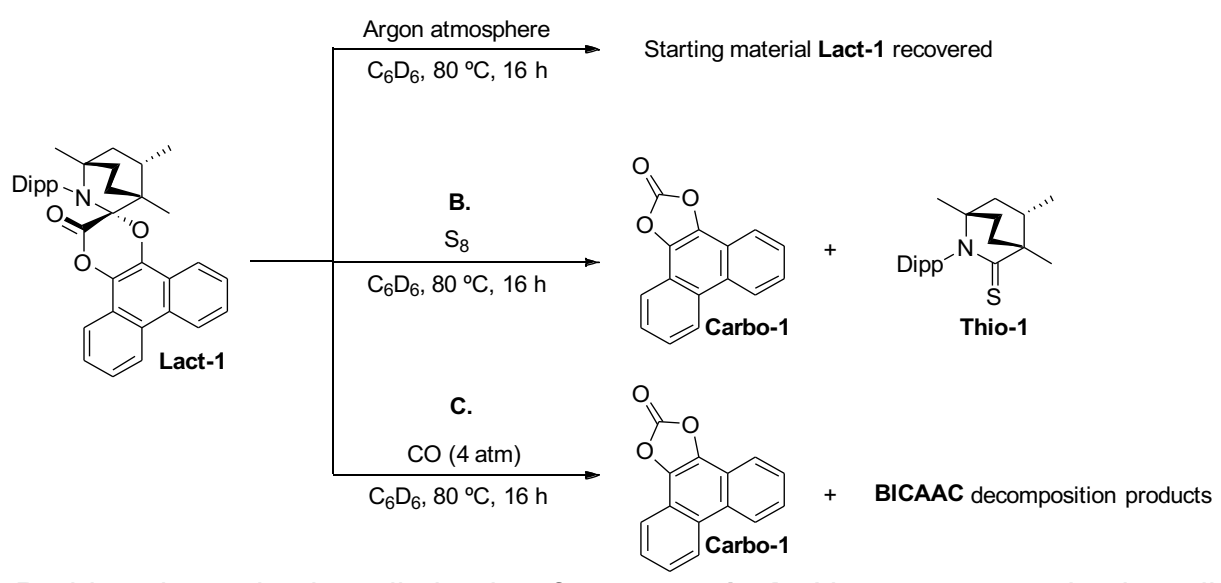

Fig. S6. Probing the reductive elimination from Lact-1; A. No apparent reductive elimination occurs under argon despite high temperature, in the absence of carbene trapping agent; $\mathbf{B}$. Equilibrium of adding and eliminating Carbo-1 is established at $80^{\circ} \mathrm{C}$ by trapping the carbene as Thio-1 with elemental sulfur; $\mathrm{C}$. Evidence for reductive elimination under $\mathrm{CO}_{(\mathrm{g})}$ at $80^{\circ} \mathrm{C}$.

\section{S2.5.1. Route A: Attempt at reductive elimination from Lact-1 at high temperature.}

In a J. Young NMR tube, Lact-1 $(0.0527 \mathrm{~g}, 0.096 \mathrm{mmol})$ was dissolved in $0.7 \mathrm{~mL}$ of $\mathrm{C}_{6} \mathrm{D}_{6}$ under an argon atmosphere and heated to $80{ }^{\circ} \mathrm{C}$ overnight. NMR analysis showed no reaction which suggested that if BICAAC and Carbo-1 are liberated via a formal reductive elimination at carbon, the reverse occurs rapidly such that no observable reaction takes place upon cooling to room temperature. 


\section{S2.5.2. Route B: Enforcing reductive elimination from Lact-1 in the presence of $\mathbf{S}_{8}$.}

In a J. Young NMR tube, Lact-1 $(0.0527 \mathrm{~g}, 0.096 \mathrm{mmol})$ was dissolved in $0.7 \mathrm{~mL}$ of $\mathrm{C}_{6} \mathrm{D}_{6}$ and then, charged with $S_{8}(2$ equivalents, $0.062 \mathrm{~g}, 0.024 \mathrm{mmol}$ ). The tube was sealed and heated to $80{ }^{\circ} \mathrm{C}$ for 16 hours. ${ }^{13} \mathrm{C}$ NMR analysis showed the clean formation of the thiolactam, Thio-1, together with the cyclic carbonate, Carbo-1. To confirm, each component of the reaction mixture was purified by silica-gel column chromatography (eluent hexane/DCM (2:1) and it NMR matched against known literature. Thio-1 was isolated as a pale-white solid. Characterization data: ${ }^{1} \mathrm{H}$ NMR $\left(500 \mathrm{MHz}, \mathrm{CDCl}_{3}\right): \delta=7.35$ (t, $\left.J=7.7 \mathrm{~Hz}, 1 \mathrm{H}\right), 7.21(\mathrm{~d}, J=7.4 \mathrm{~Hz}, 2 \mathrm{H}), 2.92$ (sept, $J=6.8 \mathrm{~Hz}, 1 \mathrm{H}$ ), 2.63 (sept, $J=6.8 \mathrm{~Hz}, 1 \mathrm{H}), 2.11-2.05(\mathrm{~m}, 2 \mathrm{H}), 2.02-1.93(\mathrm{~m}, 1 \mathrm{H}), 1.91-$ $1.84(\mathrm{~m}, 1 \mathrm{H}), 1.81-1.70(\mathrm{~m}, 2 \mathrm{H}), 1.65(\mathrm{dd}, J=7.8,3.4 \mathrm{~Hz}, 1 \mathrm{H}), 1.43(\mathrm{~s}, 3 \mathrm{H}), 1.28-1.22(\mathrm{~m}, 12 \mathrm{H})$, $1.06(\mathrm{~d}, J=6.5 \mathrm{~Hz}, 3 \mathrm{H}), 0.93(\mathrm{~s}, 3 \mathrm{H}) \mathrm{ppm} ;{ }^{13} \mathrm{C}\left\{{ }^{1} \mathrm{H}\right\}$ NMR $\left(125.7 \mathrm{MHz}, \mathrm{CDCl}_{3}\right): \delta=209.2,145.7$, 145.6, 138.0, 128.6, 124.7, 124.4, 61.7, 48.7, 44.6, 36.8, 34.4, 34.0, 29.3, 28.8, 25.6, 25.5, 24.9, 24.8, 24.5, 23.7, 19.0 ppm; IR (neat): 3057, 2959 (strong), 2927, 2866, 1669, 1446 (strong), 1392 (strong), 1265, 1178, 1065, 935, 794 (strong), $745 \mathrm{~cm}^{-1}$; HRMS (ESI): $\mathrm{m} / \mathrm{z}$ calculated for $\mathrm{C}_{22} \mathrm{H}_{34} \mathrm{NS}[\mathrm{M}+\mathrm{H}]^{+} 344.2406$; found 344.2406. Carbo-1 was isolated as a white crystalline solid. ${ }^{1} \mathrm{H}$ NMR $\left(500 \mathrm{MHz}, \mathrm{CDCl}_{3}\right): \delta=8.76-8.74(\mathrm{~m}, 2 \mathrm{H}), 8.09-8.05(\mathrm{~m}, 2 \mathrm{H}), 7.78-7.71$ $(\mathrm{m}, 4 \mathrm{H}) \mathrm{ppm} ;{ }^{13} \mathrm{C}\left\{{ }^{1} \mathrm{H}\right\}$ NMR $\left(125.7 \mathrm{MHz}, \mathrm{CDCl}_{3}\right): \delta=152.4,136.2,128.4,128.2,127.1,123.8$, 120.5, $119.2 \mathrm{ppm}$; IR (neat): $\mathrm{v}_{\text {(CO stretching) }}=1819.5 \mathrm{~cm}^{-1}$. HRMS $(\mathrm{ESI}): \mathrm{m} / \mathbf{z}$ calculated for $\mathrm{C}_{14} \mathrm{H}_{9} \mathrm{O}_{2}$ [M-CO+H] 209.0597; found 209.0596.

\section{S2.5.3. Route C: Enforcing reductive elimination from Lact-1 in the presence of $\mathrm{CO}_{(\mathrm{g}) \text {. }}$}

In a J. Young NMR tube, Lact-1 $(0.0527 \mathrm{~g}, 0.096 \mathrm{mmol})$ was dissolved in $0.7 \mathrm{~mL}$ of $\mathrm{C}_{6} \mathrm{D}_{6}$ under an argon atmosphere. The solution was cooled down to $-20{ }^{\circ} \mathrm{C}$ until the solvent froze, and it was degassed under vacuum. Carbon monoxide ( $4 \mathrm{~atm})$ was introduced into the tube and it was warmed to room temperature. The degasification/CO gas introduction process was repeated three times. Afterwards, the tube was sealed, and heated to $80{ }^{\circ} \mathrm{C}$ for 16 hours. ${ }^{13} \mathrm{C}$ NMR analysis showed the corresponding carbonate Carbo-1 was formed along with a variety of decomposition products of the BiCAAC skeleton. Ket-1 was not observed in the reaction mixture which suggests that indeed (when compared to $\mathbf{A}$ ), free carbene is released, but after reacting with $\mathrm{CO}$, it decomposes at $80^{\circ} \mathrm{C}$ in the mixture.

\section{S2.6. Reactivity of Lact-2.}
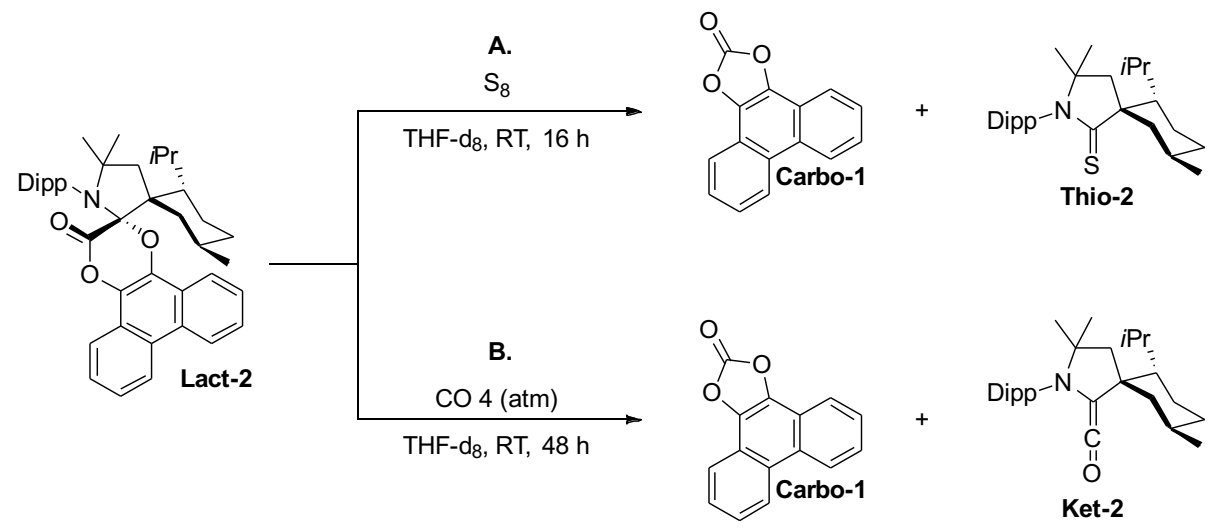

Fig. S7. Enforcing reductive elimination from Lact-2; A. Upon adding elemental sulfur, a classical carbene trapping reagent, Thio-2 is synthesized and Carbo-1 is released; B. Under 4 atm of $\mathrm{CO}_{(\mathrm{g})}$, Ket-2 is formed from the free-carbene upon eliminating Carbo-1.

\section{S2.6.1. Route A: Enforcing reductive elimination from Lact-2 in the presence of $S_{8}$.}

In a J. Young NMR tube, Lact-2 $(0.050 \mathrm{~g}, 0.0809 \mathrm{mmol})$ was dissolved in $0.7 \mathrm{~mL}$ of dry deuterated tetrahydrofuran under an argon atmosphere. Then, 1 equiv. of sulfur, $\mathrm{S}_{8}(0.0026 \mathrm{~g}$, $0.0101 \mathrm{mmol}$ ), was added to the colorless solution which immediately began to turn light yellow. After 16 hours, NMR analysis showed quantitative formation of Carbo-1 and the thiolactam 
Thio-2 (see Fig. S40-S41). To confirm, each component of the reaction mixture was purified by silica-gel column chromatography (eluent hexane/DCM (2:1) and its NMR matched against known literature. ${ }^{5}$ Thio-2 was isolated as a white solid. Characterization data: ${ }^{1} \mathbf{H}$ NMR (500 $\mathrm{MHz}$, THF-d8): $\delta=7.31-7.27(\mathrm{~m}, 1 \mathrm{H}), 7.22-7.19(\mathrm{~m}, 2 \mathrm{H}), 2.93-2.80(\mathrm{~m}, 4 \mathrm{H}), 2.50(\mathrm{~d}, J=13.6$ $\mathrm{Hz}, 1 \mathrm{H}$ ), 2.14 (dt, , $J=13.6,2.8 \mathrm{~Hz}, 1 \mathrm{H}), 2.05$ (sept, $J=7.0 \mathrm{~Hz}, 1 \mathrm{H}), 1.97$ (d, $J=13.6 \mathrm{~Hz}, 1 \mathrm{H}$ ), 1.87-1.83 (m, 1H), 1.43-1.37 (m, 1H), $1.33(\mathrm{~s}, 3 \mathrm{H}), 1.26-1.25(\mathrm{~m}, 6 \mathrm{H}), 1.23(\mathrm{~s}, 3 \mathrm{H}), 1.22-1.21$ (m, 1H), 1.18-1.15 (m, 6H), $1.07(\mathrm{~d}, J=6.9 \mathrm{~Hz}, 3 \mathrm{H}), 1.01(\mathrm{~d}, J=6.9 \mathrm{~Hz}, 3 \mathrm{H}), 0.81(\mathrm{~d}, J=6.6$ $\mathrm{Hz}, 3 \mathrm{H}) \mathrm{ppm} ;{ }^{13} \mathrm{C}\left\{{ }^{1} \mathrm{H}\right\}$ NMR $\left(125.7 \mathrm{MHz}, \mathrm{THF}-\mathrm{d}_{8}\right): \delta=209.9,148.2,148.2,134.1,129.3,125.3$, 124.9, 68.6, 58.4, 54.2, 53.0, 51.9, 36.6, 30.3, 30.3, 30.1, 30.0, 29.3, 27.9, 26.8, 26.6, 23.7, 23.4, 23.1, 23.0, $20.1 \mathrm{ppm}$.

\section{S2.6.2. Route $B$ : Enforcing reductive elimination from Lact-2 in the presence of $\mathrm{CO}_{(\mathrm{g}) \text {. }}$}

In a heavy wall J. Young NMR tube, Lact-2 $(0.005 \mathrm{~g}, 0.00809 \mathrm{mmol})$ was dissolved in $0.1 \mathrm{~mL}$ of dry deuterated tetrahydrofuran under an argon atmosphere. The solution was cooled down with liquid nitrogen until the solvent froze, and it was degassed under vacuum. Carbon monoxide (4 atm) was introduced into the tube and it was warmed to room temperature. The degasification/CO gas introduction process was repeated three times. The tube was left at room temperature for 95 hours. Over the course of that period, NMR was used to monitor the solution and probe the equilibrium. ${ }^{13} \mathrm{C}$ NMR analysis confirmed the presence of the Ket-2 in the mixture (see Fig. S42-S45).

S2.7. Ethylene carbonate: enabling the observation of a kinetic vs a thermodynamic spirolactone.

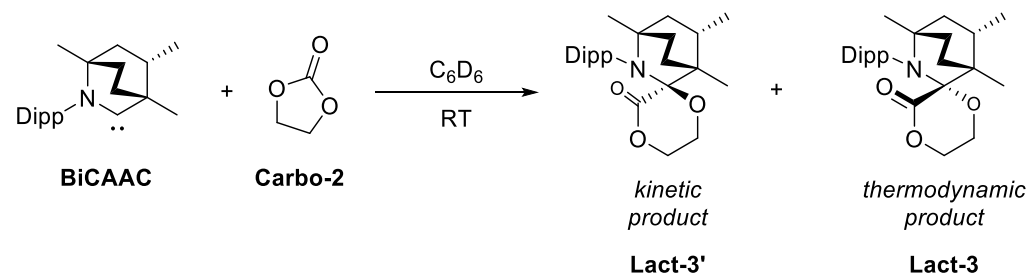

Fig. S8. The reaction of BiCAAC with Carbo-2 leads to the observation of a kinetic product, Lact-3', and a thermodynamic product, Lact-3.

In a J. Young NMR tube, free BiCAAC $(0.030 \mathrm{~g}, 0.096 \mathrm{mmol})$ was dissolved in $0.7 \mathrm{~mL}$ of dry deuterated benzene. Then, at room temperature, ethylene carbonate, Carbo-2 $(0.008 \mathrm{~g}, 0.096$ $\mathrm{mmol}$ ), was added to the solution and the reaction was followed by NMR analysis. A mixture of diastereoisomers were formed in 74/26 ratio (kinetic product, Lact-3'/thermodynamic product, Lact-3). Characterization in situ: Lact-3' (kinetic): ${ }^{1} \mathrm{H}$ NMR $\left(500 \mathrm{MHz}, \mathrm{C}_{6} \mathrm{D}_{6}\right): \delta=7.16-7.06$ (m, 3H), 3.96 (sept, $J=6.9 \mathrm{~Hz}, 1 \mathrm{H}$ ), 3.71 (sept, $J=6.9 \mathrm{~Hz}, 1 \mathrm{H}$ ), 3.31 (ddd, $J=10.7,8.0,2.6 \mathrm{~Hz}$, 1H), 2.92 (ddd, $J=12.6,4.6,2.6 \mathrm{~Hz}, 1 \mathrm{H}$ ), 2.84 (ddd, $J=10.8,4.4,2.3 \mathrm{~Hz}, 1 \mathrm{H}$ ), 2.58 (ddd, $J=$ 12.7, 8.0, 2.2 Hz, 1H), 2.54-2.47 (m, 2H), 1.93 (ddd, $J=13.2,7.7,2.2 \mathrm{~Hz}, 1 \mathrm{H}), 1.79-1.65(\mathrm{~m}$, 2H), $1.44(\mathrm{~d}, J=6.9 \mathrm{~Hz}, 3 \mathrm{H}), 1.34(\mathrm{~d}, J=6.9 \mathrm{~Hz}, 3 \mathrm{H}), 1.23(\mathrm{~d}, J=6.9 \mathrm{~Hz}, 3 \mathrm{H}), 1.20(\mathrm{~d}, J=6.9$ $\mathrm{Hz}, 3 \mathrm{H}), 1.14(\mathrm{~d}, J=6.9 \mathrm{~Hz}, 3 \mathrm{H}), 1.03-0.91(\mathrm{~m}, 1 \mathrm{H}), 0.82(\mathrm{~s}, 3 \mathrm{H}), 0.94(\mathrm{~s}, 3 \mathrm{H}) \mathrm{ppm} ;{ }^{13} \mathrm{C}\left\{{ }^{1} \mathrm{H}\right\}$ NMR $\left(125.7 \mathrm{MHz}, \mathrm{C}_{6} \mathrm{D}_{6}\right): \delta=168.6,153.5,152.8,137.8,128.0,125.8,124.4,96.8,67.2,63.1$, 54.1, 47.3, 43.0, 37.2, 33.4, 29.2, 28.9, 26.8, 26.7, 26.3, 25.3, 24.8, 19.6, 16.4 ppm. Lact-3 (thermodynamic): ${ }^{1} \mathrm{H}$ NMR $\left(500 \mathrm{MHz}, \mathrm{C}_{6} \mathrm{D}_{6}\right): \delta=7.16-7.06(\mathrm{~m}, 3 \mathrm{H}), 3.96$ (sept, $J=6.7 \mathrm{~Hz}$, $1 \mathrm{H}), 3.73$ (sept, $J=6.7 \mathrm{~Hz}, 1 \mathrm{H}), 3.33-3.26(\mathrm{~m}, 1 \mathrm{H}), 3.23-3.16(\mathrm{~m}, 1 \mathrm{H}), 3.08-3.01(\mathrm{~m}, 2 \mathrm{H}), 2.98-$ $2.91(\mathrm{~m}, 1 \mathrm{H}), 2.16(\mathrm{tt}, J=12.1,4.1 \mathrm{~Hz}, 1 \mathrm{H}), 1.93(\mathrm{ddd}, J=12.9,7.2,3.7 \mathrm{~Hz}, 1 \mathrm{H}), 1.76(\mathrm{t}, J=$ $12.0 \mathrm{~Hz}, 1 \mathrm{H}), 1.52(\mathrm{~d}, J=6.7 \mathrm{~Hz}, 3 \mathrm{H}), 1.29(\mathrm{~d}, J=7.2 \mathrm{~Hz}, 3 \mathrm{H}), 1.18(\mathrm{~d}, J=6.7 \mathrm{~Hz}, 3 \mathrm{H}), 1.17(\mathrm{~d}$, $J=6.7 \mathrm{~Hz}, 3 \mathrm{H}), 1.15(\mathrm{~d}, J=6.7 \mathrm{~Hz}, 3 \mathrm{H}), 1.05(\mathrm{~s}, 3 \mathrm{H}), 0.76(\mathrm{~s}, 3 \mathrm{H}) \mathrm{ppm} ;{ }^{13} \mathrm{C}\left\{{ }^{1} \mathrm{H}\right\}$ NMR $(125.7$ $\left.\mathrm{MHz}, \mathrm{C}_{6} \mathrm{D}_{6}\right): \delta=166.1,153.1,152.8,138.4,128.2,125.5,124.7,99.8,67.2,63.6,63.1,54.5$, $45.3,42.3,39.2,35.8,34.4,29.6,28.9,26.5,26.2,26.1,25.6,25.2,20.1,19.9$ ppm. 
S2.7.1. Isomerization between the kinetic product, Lact-3', and the thermodynamic product, Lact-3, after elevated temperatures.

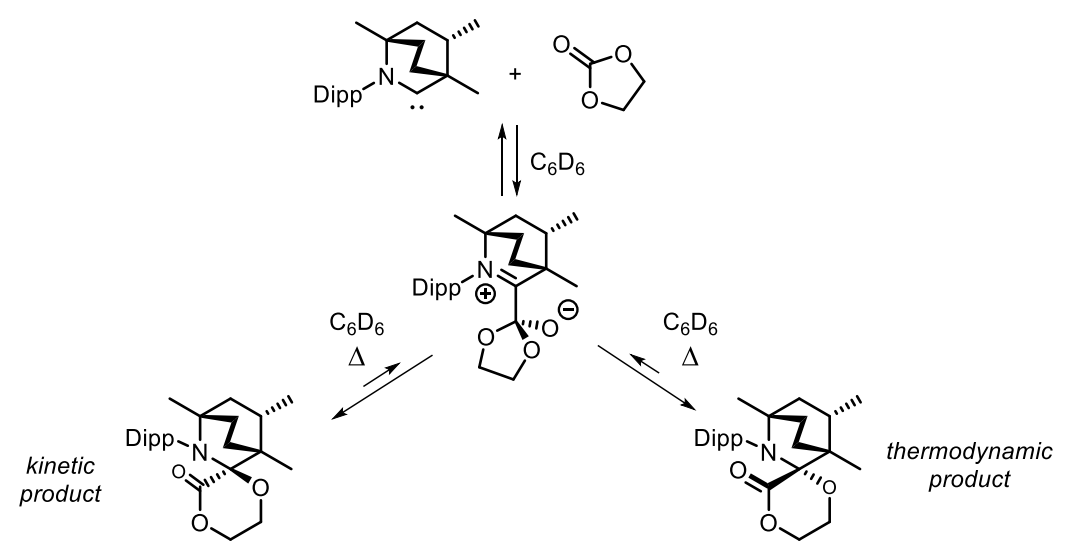

Fig. S9. The isomerization between Lact-3' and Lact-3 can be achieved at $80^{\circ} \mathrm{C}$ after 24 hours.

Upon taking the mixture of diastereoisomers, formed in a 74/26 ratio (vide supra), in a J. Young tube and by heating the reaction mixture to $80^{\circ} \mathrm{C}$ for 24 hours, the ratio was inverted and equilibrium was achieved as demonstrated by ${ }^{1} \mathrm{H}$ NMR (see Fig. S50).

S2.7.2. Trapping the free BiCAAC by reductively eliminating Carbo-2 from Lact-3/Lact-3' at elevated temperatures.

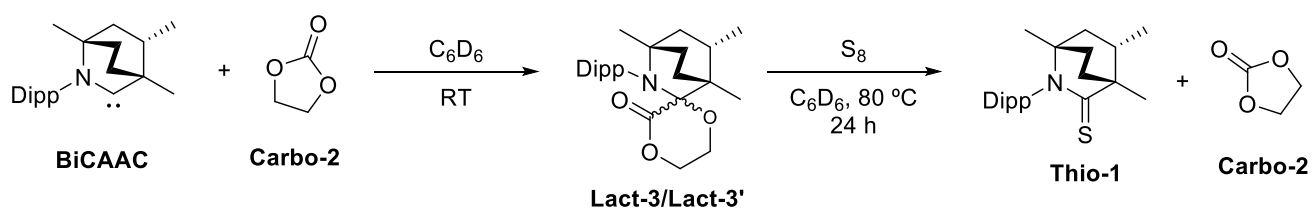

Fig. S10. After the formation of Lact-3/Lact-3', BiCAAC was trapped with elemental sulfur after releasing Carbo-2 at $80{ }^{\circ} \mathrm{C}$.

In a J. Young NMR tube, free BiCAAC $(0.030 \mathrm{~g}, 0.096 \mathrm{mmol})$ was dissolved in $0.7 \mathrm{~mL}$ of dry deuterated benzene. Then, at room temperature, Carbo-2 $(0.008 \mathrm{~g}, 0.096 \mathrm{mmol})$ was added to the solution and led to the mixture of Lact-3 and Lact-3'. Next, elemental sulfur was added, and the tube was heated overnight at $80{ }^{\circ} \mathrm{C}$ to trap the free carbene. NMR analysis showed the formation of Thio-1 and the release of Carbo-2 (see Figs. S51-S52).

\section{S2.8. CAAC-catalyzed carbonylation of quinones with $\mathrm{CO}_{(\mathrm{g})}$.}
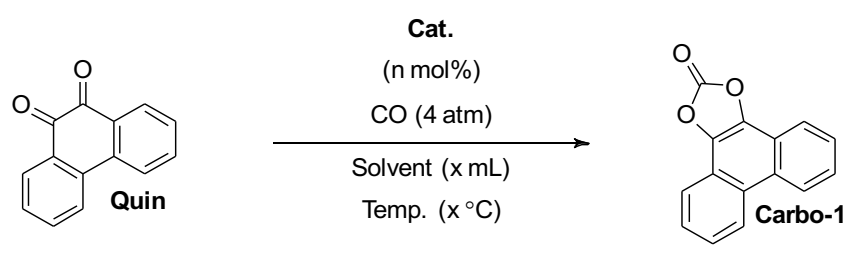

Fig. S11. Optimizing the catalytic carbonylation of o-quinones to cyclic carbonates by a carbene catalyst with $\mathrm{CO}_{(\mathrm{g})}$.

\section{S2.8.1. Optimization: Procedure A for Table S1.}

In a $100 \mathrm{~mL}$ Teflon-capped pressure Schlenk, the corresponding amount of free-carbene cat. ( $\mathrm{n}$ mol\% catalyst loading, see table), and the corresponding amount of Quin ( $\mathrm{nmmol}$, see table) were added to solution, and the dry solvent ( $\mathrm{x} \mathrm{mL}$, see table) was added to the mixture. The solution was cooled down until the solvent froze, and it was degassed under vacuum. Carbon monoxide (4 atm) was introduced into the flask and it was warmed to room temperature. The degasification/CO gas introduction process was repeated three times. The flask was sealed and 
stirred at 500 RPM at the corresponding temperature (Temp. ${ }^{\circ} \mathrm{C}$, see table) for the desired duration of time (Time hours, see table). Upon completion of the catalysis, the vessel was removed from the heat, cooled to room temperature, and then the solvent was completely removed under vacuum. The resulting orange to pale yellow solid was then opened to the atmosphere, and the solid was completely dissolved in a $2 \mathrm{~mL}$ stock solution of $\mathrm{CDCl}_{3}$ with 1,3,5-Trimethoxybenzene as a standard $(5.95 \mathrm{mM}) .{ }^{1} \mathrm{H}$ NMR analysis was then used to determine the TON and the conversion to the resulting Carbo-1, with respect to the standard.

\section{S2.8.2. Optimization: Procedure B for Table S1.}

In a $100 \mathrm{~mL}$ Teflon-capped pressure Schlenk, the corresponding amount of CAAC ( $\mathrm{n} \mathrm{mol \%}$ catalyst loading, see table) was dissolved in $1 / 3$ of the corresponding total dry solvent to be used in the catalysis (see below). After one freeze-pump-thaw, the solution was put under 1 atmosphere of $\mathrm{CO}$. After the solution became dark blue, the pressure Schlenk was introduced into the glovebox, the corresponding amount of Quin ( $\mathrm{nmmol}$, see table) was added to solution, and the rest of the dry solvent was added to the mixture (total solvent $x \mathrm{~mL}$, see table). The solution was cooled down to $-20^{\circ} \mathrm{C}$ until the solvent froze, and it was degassed under vacuum. Carbon monoxide was introduced in the flask and let it warm to room temperature. The degasification/CO gas introduction process was repeated three times. The flask was sealed and stirred at 500 RPM at the corresponding temperature (Temp. ${ }^{\circ} \mathrm{C}$, see table) for the desired duration (Time hours, see table). Upon completion of the catalysis, the vessel was removed from the heat, cooled to room temperature, and then the solvent was completely removed under vacuum. The resulting solid was then opened to the atmosphere, completely dissolved in a stock solution of $\mathrm{CDCl}_{3}$ with 1,3,5-Trimethoxybenzene as a standard $(5.95 \mathrm{mM})(2 \mathrm{~mL}$ of stock solution for Quin/Carbo-1). ${ }^{1} \mathrm{H}$ NMR was then used to determine the TON and the conversion to the resulting Carbo-1.

\begin{tabular}{|c|c|c|c|c|c|c|c|}
\hline Procedure & $\begin{array}{l}\text { Orthoquinone } \\
\quad(\mathrm{mmol})\end{array}$ & $\begin{array}{l}\text { Catalyst Loading } \\
(\mathrm{mol} \%)\end{array}$ & $\mathrm{T}\left({ }^{\circ} \mathrm{C}\right)$ & $\mathrm{t}(\mathrm{hr})$ & $\begin{array}{l}\text { Conv. } \% \\
\text { by }{ }^{1} \mathrm{H} \\
\text { NMR }\end{array}$ & Solvent (mL) & TON \\
\hline$A$ & Quin (0.131) & CAAC $(20)$ & 60 & 24 & 100 & Benzene (2) & 5 \\
\hline A & Quin (0.262) & None & 60 & 24 & 0 & Benzene (2) & 0 \\
\hline$A$ & Quin (0.131) & BiCAAC (20) & 60 & 24 & 0 & Benzene (2) & 0 \\
\hline$A$ & Quin (0.131) & CAAC $^{\mathrm{Me}}(20)$ & 60 & 24 & 0 & Benzene (2) & 0 \\
\hline A & Quin (0.262) & CAAC (10) & 60 & 24 & 33 & Benzene (2) & 3 \\
\hline$A$ & Quin $(0.262)$ & CAAC (10) & 60 & 24 & 8.2 & THF (2) & 0 \\
\hline A & Quin (0.262) & CAAC (10) & 60 & 24 & 7.5 & Pentane (2) & 0 \\
\hline A & Quin (0.262) & CAAC (10) & 60 & 24 & 23.5 & Toluene (2) & 2 \\
\hline A & Quin $(0.262)$ & CAAC (10) & 60 & 24 & 5.5 & Dioxane (2) & 0 \\
\hline A & Quin (0.262) & CAAC (10) & 60 & 24 & 4.2 & $\begin{array}{c}\text { Dimethoxyethane } \\
\text { (2) }\end{array}$ & 0 \\
\hline A & Quin $(0.262)$ & CAAC (10) & 60 & 24 & 8.3 & Diethyl ether (2) & 0 \\
\hline A & Quin $(0.262)$ & CAAC (10) & 50 & 24 & 18.7 & Benzene (2) & 1 \\
\hline A & Quin (0.262) & CAAC (10) & 70 & 24 & 4.8 & Benzene (2) & 0 \\
\hline$A$ & Quin $(0.262)$ & CAAC (10) & 80 & 24 & 4.5 & Benzene (2) & 0 \\
\hline A & Quin (0.262) & CAAC (10) & Sonic. & 24 & 16.7 & Benzene (2) & 1 \\
\hline$B$ & Quin (0.262) & CAAC (10) & 60 & 24 & 45.7 & Benzene (2) & 4 \\
\hline B & Quin (0.262) & CAAC (10) & 60 & 16 & 28.1 & Benzene (2) & 2 \\
\hline$B$ & Quin (0.262) & CAAC (10) & 60 & 36 & 49.5 & Benzene (2) & 4 \\
\hline B & Quin (0.262) & CAAC (10) & 60 & 40 & $80.1^{a}$ & Benzene (3) & 8 \\
\hline$B$ & Quin $(0.262)$ & CAAC (12.5) & 60 & 40 & 100 & Benzene (3) & 8 \\
\hline
\end{tabular}

Table S1. Catalytic Optimization Table. ${ }^{a}$ Isolated Yield by florisil column chromatography of small-scale reaction determined to be $79.6 \%$. 


\section{S2.8.3. Catalytic procedure.}

In a $500 \mathrm{~mL}$ Teflon-capped pressure Schlenk, the corresponding amount of CAAC (12.5 mol\% compared to Quin/Carbo-1) was dissolved in 1/3 of the corresponding total dry benzene to be used in the catalysis. After one freeze-pump-thaw, the solution was put under 1 atmosphere of CO. After the solution became dark blue, the pressure Schlenk was introduced into the glovebox, Quin $(2.401 \mathrm{mmol})$ was added to solution, and the rest of the dry benzene was added to the mixture (total of $27.5 \mathrm{~mL}$ for Quin/Carbo-1). The solution was cooled down to $-20^{\circ} \mathrm{C}$ until the solvent froze, and it was degassed under vacuum. Carbon monoxide (4 atm) was introduced into the flask and it was warmed to room temperature. The degasification/CO gas introduction process was repeated three times. The flask was sealed and stirred at 500 RPM at $60{ }^{\circ} \mathrm{C}$ for 40 hours. Upon completion of the catalysis, the vessel was removed from the heat, cooled to room temperature, the solvent was completely removed under vacuum, and then the resulting mixture was purified (see below).

S2.8.4. Catalysis: Quin, CO, and CAAC catalyst afford Carbo-1.

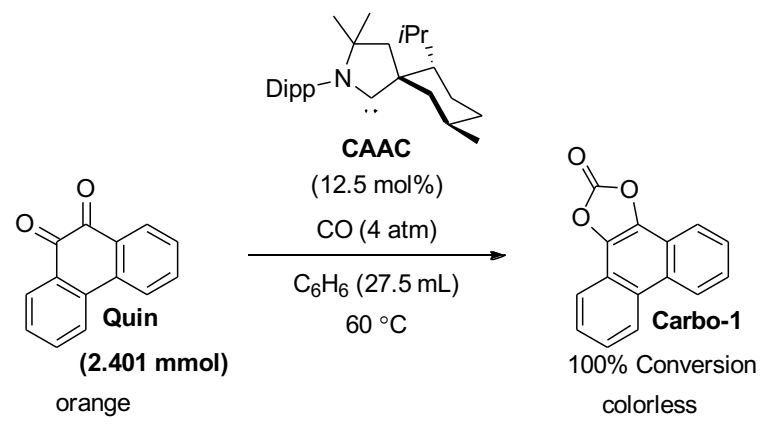

Fig. S12. Catalytic carbonylation of Quin to Carbo-1 by CAAC catalyst with $\mathrm{CO}_{(\mathrm{g})}$.

Purification: From the pale white solid, Carbo-1 was purified via removing the CAAC decomposition product by simply washing with pentane $(3 \times 2 \mathrm{~mL})$. NB: if there is any Quin left in the mixture, Florisil adsorbent column chromatography is ideal for further purification (eluent hexane/DCM (2:1)). Carbo-1 yield 97.3\% (0.552 g). Carbo-1: white crystalline solid. Characterization data: ${ }^{1} \mathrm{H}$ NMR $\left(500 \mathrm{MHz}, \mathrm{CDCl}_{3}\right): \delta=8.76-8.74(\mathrm{~m}, 2 \mathrm{H}), 8.09-8.05(\mathrm{~m}, 2 \mathrm{H})$, 7.78-7.71 (m, 4H) ppm; ${ }^{13} \mathrm{C}\left\{{ }^{1} \mathrm{H}\right\}$ NMR $\left(125.7 \mathrm{MHz}, \mathrm{CDCl}_{3}\right): \delta=152.4,136.2,128.4,128.2$, 127.1, 123.8, 120.5, 119.2 ppm; IR (neat): $\mathrm{V}_{\text {(CO stretching) }}=1819.5 \mathrm{~cm}^{-1} ;$ HRMS (ESI): $\mathrm{m} / \mathbf{z}$ calculated for $\mathrm{C}_{14} \mathrm{H}_{9} \mathrm{O}_{2}[\mathrm{M}-\mathrm{CO}+\mathrm{H}]^{+}$209.0597; found 209.0596; $\mathbf{X}$-ray see below.

\section{S2.9. Catalyst deactivation study.}

\section{S2.9.1. Control experiment: reaction between CAAC and Quin.}

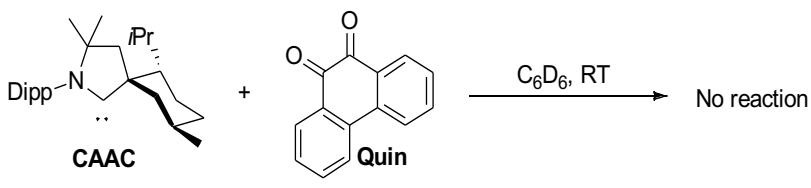

Fig. S13. Sterically bulky CAAC as an active catalyst does not react with substrate Quin.

As observed before in the synthesis of compound CAAC (procedure $\mathbf{A}$ ), there is no reaction between free CAAC $(0.030 \mathrm{~g}, 0.079 \mathrm{mmol}$ ) and 1,9-phenanthrenequinone (Quin; $0.0164 \mathrm{~g}$, $0.079 \mathrm{mmol}$ ) in $0.7 \mathrm{~mL}$ of dry deuterated benzene under an argon atmosphere. 
S2.9.2. Reaction of BiCAAC with Quin.

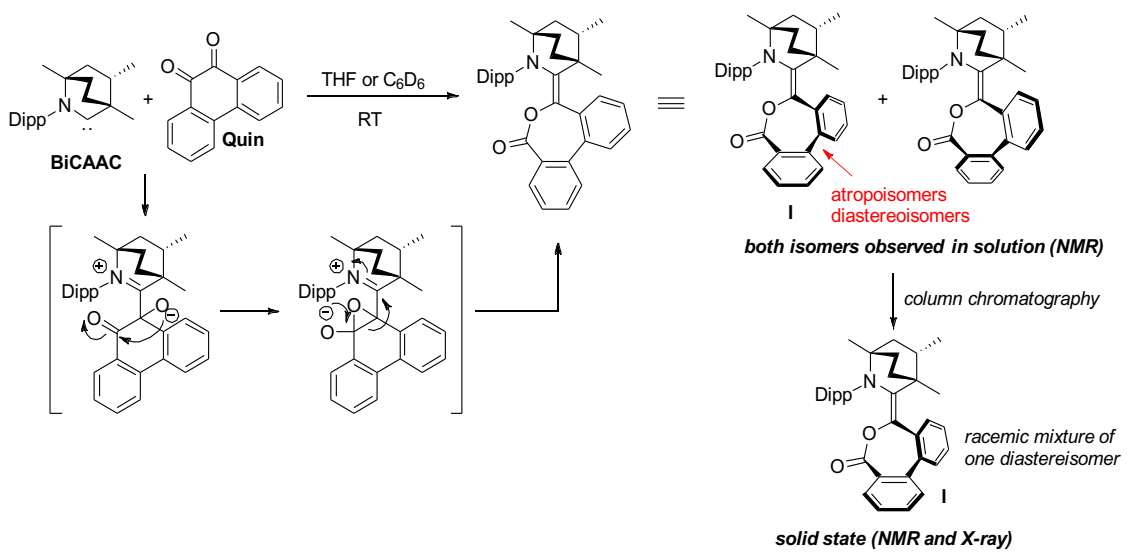

Fig. S14. Catalyst deactivation of BiCAAC by substrate Quin with proposed mechanism leading to a diastereomeric mixture of atropisomers, and the subsequent purification to isolate I by silica gel column chromatography.

BiCAAC $(0.050 \mathrm{~g}, 0.16 \mathrm{mmol})$ was dissolved in $1 \mathrm{~mL}$ of dry THF under an Argon atmosphere at room temperature. Then, 9,10-phenanthrenequinone (Quin) was added $(0.027 \mathrm{~g}, 0.13 \mathrm{mmol}$ ) forming a homogeneous deep purple-reddish solution. After stirring for 10 minutes, volatiles were removed. The mixture was analyzed by means of NMR spectroscopy showing variable mixture of isomers in each batch (around 1:1). The product was purified by silica-gel column chromatography (eluent hexane/DCM (1:2)). A single isomer as a pale-yellow product was isolated $\left(R_{f}=0.3\right)$. Yield $39 \%(0.030 \mathrm{~g})$. X-ray quality crystals were grown after slow evaporation of the solvent. Characterization data: ${ }^{1} \mathrm{H}$ NMR $\left(500 \mathrm{MHz}, \mathrm{CDCl}_{3}\right): \delta=7.64(\mathrm{~d}, J=7.8 \mathrm{~Hz}, 1 \mathrm{H})$, $7.51(\mathrm{t}, J=7.4 \mathrm{~Hz}, 1 \mathrm{H}), 7.45-7.32(\mathrm{~m}, 4 \mathrm{H}), 7.31-7.25(\mathrm{~m}, 2 \mathrm{H}), 7.18(\mathrm{~s}, 1 \mathrm{H}), 7.17(\mathrm{~s}, 1 \mathrm{H}), 3.40$ (sept, $J=6.8 \mathrm{~Hz}, 1 \mathrm{H}$ ), 3.28 (sept, $J=6.8 \mathrm{~Hz}, 1 \mathrm{H}), 2.12-2.00(\mathrm{~m}, 2 \mathrm{H}), 1.92-1.86(\mathrm{~m}, 1 \mathrm{H}), 1.65-$ $1.56(\mathrm{~m}, 3 \mathrm{H}), 1.53-1.49(\mathrm{~m}, 1 \mathrm{H}), 1.36(\mathrm{~d}, J=6.8 \mathrm{~Hz}, 3 \mathrm{H}), 1.31(\mathrm{t}, J=7.0 \mathrm{~Hz}, 3 \mathrm{H}), 1.29(\mathrm{t}, J=7.0$ $\mathrm{Hz}, 3 \mathrm{H}), 1.22(\mathrm{~d}, J=6.8 \mathrm{~Hz}, 3 \mathrm{H}), 0.74(\mathrm{~s}, 3 \mathrm{H}), 0.41(\mathrm{~d}, J=7.0 \mathrm{~Hz}, 3 \mathrm{H}), 0.34(\mathrm{~s}, 3 \mathrm{H}), \mathrm{ppm}$; ${ }^{13} \mathrm{C}\left\{{ }^{1} \mathrm{H}\right\}$ NMR $\left(125.7 \mathrm{MHz}, \mathrm{CDCl}_{3}\right): \delta=169.6,147.7,146.7,141.0,140.5,140.1,139.6,133.3$, 132.8, 131.4, 131.3, 128.9, 127.6, 127.4, 127.1, 127.0, 127.0, 123.8, 123.7, 118.9, 56.5, 43.7, 40.3, 39.0, 36.0, 35.0, 28.7, 28.4, 27.4, 26.2, 26.1, 25.3, 24.9, 24.0, 18.2 ppm; IR (neat): v(Co stretching) $=1716.3(\mathrm{~s}) \mathrm{cm}^{-1}$; HRMS $(\mathrm{ESI}): \mathrm{m} / \mathrm{z}$ calculated for $\mathrm{C}_{36} \mathrm{H}_{42} \mathrm{NO}_{2}[\mathrm{M}+\mathrm{H}]^{+} 520.3210$; found 520.3207; X-ray see below.

S2.9.3. Control experiment between CAAC $^{\mathrm{Me}}$ and Quin.

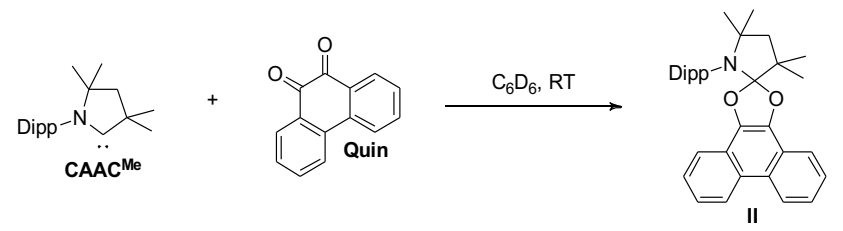

Fig. S15. Catalyst deactivation of sterically unencumbered CAAC ${ }^{\mathrm{Me}}$ by substrate Quin leading to the synthesis of II.

CAACMe $^{\mathrm{M}}(0.050 \mathrm{~g}, 0.175 \mathrm{mmol})$ and Quin $(0.0365 \mathrm{~g}, 0.175 \mathrm{mmol})$ were dissolved in $0.7 \mathrm{~mL}$ of benzene to give the quantitative and clean formation of II. Volatiles were removed under vacuum and the solid was washed with $1 \mathrm{~mL}$ of pentane. X-ray quality crystals were grown by the slow evaporation of a saturated solution in benzene. Yield $88 \%(0.076 \mathrm{~g})$. Characterization data: ${ }^{1} \mathrm{H}$ NMR $\left(500 \mathrm{MHz}, \mathrm{C}_{6} \mathrm{D}_{6}\right): \delta=8.37(\mathrm{~d}, J=8.4 \mathrm{~Hz}, 2 \mathrm{H}), 8.10(\mathrm{dd}, J=8.1,0.8 \mathrm{~Hz}, 2 \mathrm{H}), 7.38$ (dt, $J=7.5,0.8 \mathrm{~Hz}, 2 \mathrm{H}), 7.23$ (dt, $J=7.7,1.3 \mathrm{~Hz}, 2 \mathrm{H}$ ), 7.08 (br, 3H), 4.03 (sept, $J=6.8 \mathrm{~Hz}, 2 \mathrm{H}$ ), $1.90(\mathrm{~s}, 2 \mathrm{H}), 1.37(\mathrm{~d}, J=6.8 \mathrm{~Hz}, 6 \mathrm{H}), 1.34-1.33(\mathrm{~m}, 12 \mathrm{H}), 1.22(\mathrm{~s}, 6 \mathrm{H}) \mathrm{ppm} ;{ }^{13} \mathrm{C}\left\{{ }^{1} \mathrm{H}\right\}$ NMR (125.7 MHz, $\left.\mathrm{C}_{6} \mathrm{D}_{6}\right): \delta=152.8,138.4,134.9,132.1,128.5,127.0,126.8,124.9,124.1,123.7$, 121.6, 120.7, 62.0, 52.4, 46.7, 30.6, 29.2, 27.6, 27.1, 24.6 ppm; X-ray see below. 


\section{S3. X-Ray crystal structure determination.}

Olex2 software ${ }^{6}$ was employed for the resolution, refinement, and generation of crystallographic information files of every structure. The structures were solved with the ShelXS97 ${ }^{7}$ structure solution program using Direct Methods and refined with the ShelXL ${ }^{7}$ refinement package using Least Squares minimization. During the final stages of the refinements, all the positional parameters and the anisotropic temperature factors of all the non- $\mathrm{H}$ atoms were refined. The $\mathrm{H}$ atoms were geometrically located and their coordinates were refined riding on their parent atoms.

S3.1. X-Ray data and structure for Lact-1.

\begin{tabular}{|c|c|}
\hline Identification code & Lact-1 \\
\hline Empirical formula & $\mathrm{C}_{37} \mathrm{H}_{41} \mathrm{NO}_{3}$ \\
\hline Formula weight & 547.71 \\
\hline Temperature/K & 100.0 \\
\hline Crystal system & triclinic \\
\hline Space group & $P-1$ \\
\hline$a / \AA ̊$ & $13.522(2)$ \\
\hline $\mathrm{b} / \AA ̊$ & $14.662(2)$ \\
\hline $\mathrm{c} / \AA \AA$ & $15.587(3)$ \\
\hline$\alpha /^{\circ}$ & $70.362(5)$ \\
\hline$\beta /^{\circ}$ & $82.086(6)$ \\
\hline $\mathrm{y} /{ }^{\circ}$ & $89.869(5)$ \\
\hline Volume/ $\AA^{3}$ & $2879.6(8)$ \\
\hline Z & 4 \\
\hline$\rho_{\text {calc }} \mathrm{g} / \mathrm{cm}^{3}$ & 1.263 \\
\hline$\mu / \mathrm{mm}^{-1}$ & 0.079 \\
\hline$F(000)$ & 1176.0 \\
\hline Crystal size/mm³ & $0.3 \times 0.1 \times 0.1$ \\
\hline Radiation & $\operatorname{MoKa}(\lambda=0.71073)$ \\
\hline \multicolumn{2}{|c|}{$2 \Theta$ range for data collection $/{ }^{\circ} 2.952$ to 50.884} \\
\hline Index ranges & $-16 \leq \mathrm{h} \leq 14,-17 \leq \mathrm{k} \leq 17,-18 \leq \mathrm{I} \leq 18$ \\
\hline Reflections collected & 60474 \\
\hline Independent reflections & $10618\left[R_{\text {int }}=0.0469, R_{\text {sigma }}=0.0320\right]$ \\
\hline Data/restraints/parameters & $10618 / 0 / 754$ \\
\hline Goodness-of-fit on $\mathrm{F}^{2}$ & 1.043 \\
\hline Final $R$ indexes $[I>=2 \sigma(I)]$ & $\mathrm{R}_{1}=0.0431, w \mathrm{R}_{2}=0.1031$ \\
\hline Final $R$ indexes [all data] & $\mathrm{R}_{1}=0.0557, \mathrm{wR}_{2}=0.1114$ \\
\hline Largest diff. peak/hole / e $\AA^{-}$ & $0.38 /-0.25$ \\
\hline
\end{tabular}

Table S2. Crystal structure and refinement data for Lact-1 (\#CCDC: 1999858). 


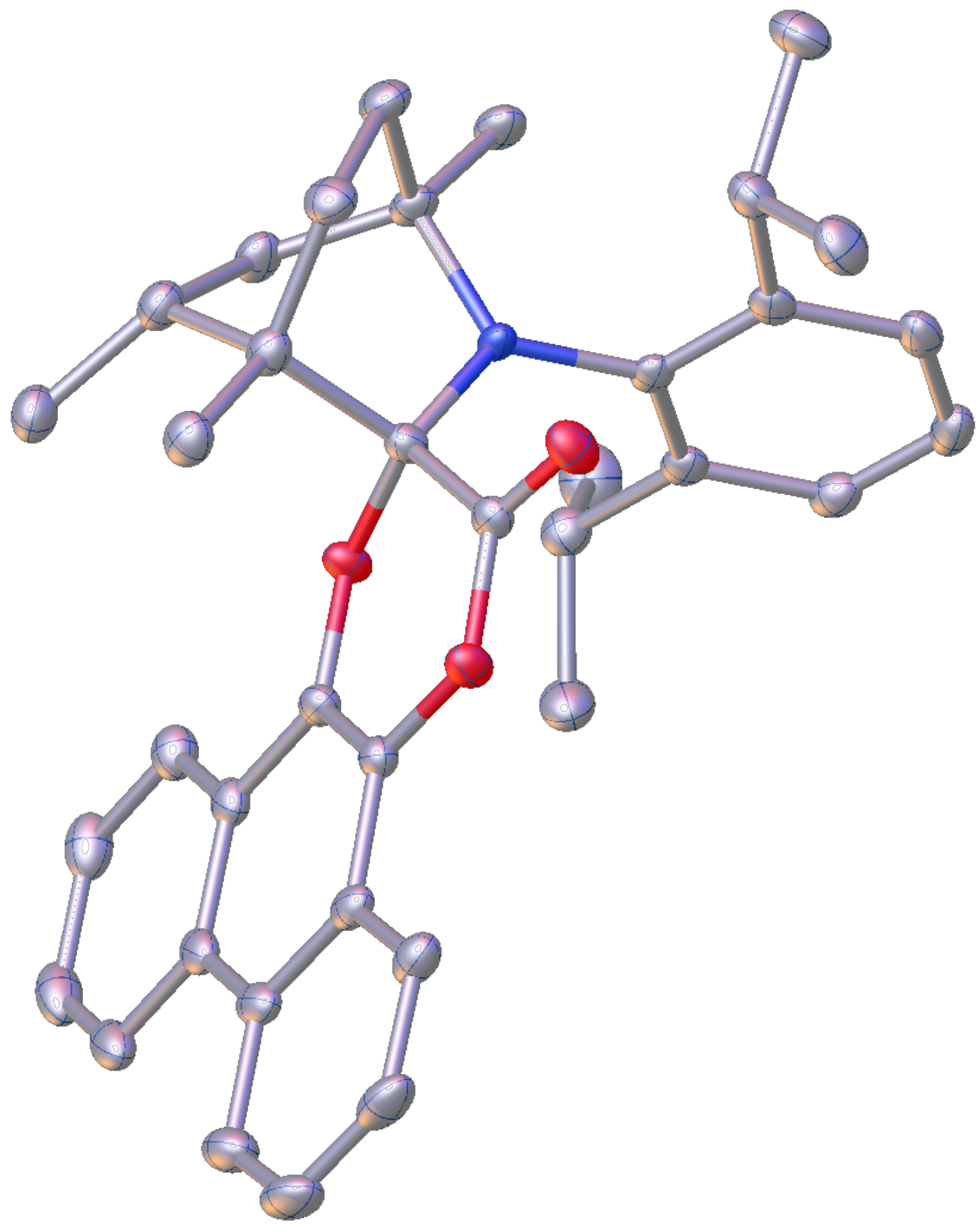

Fig. S16. X-ray structure of Lact-1 (Ellipsoids shown at 30\% probability; Hydrogen atoms have been omitted for clarity). 
S3.2. X-Ray data and structure for Lact-2.

\begin{tabular}{|c|c|}
\hline Identification code & Lact-2 \\
\hline Empirical formula & $\mathrm{C}_{42} \mathrm{H}_{51} \mathrm{NO}_{3}$ \\
\hline Formula weight & 617.83 \\
\hline Temperature/K & 100.0 \\
\hline Crystal system & monoclinic \\
\hline Space group & $\mathrm{P} 2{ }_{1}$ \\
\hline$a / \AA ̊$ & $9.6614(2)$ \\
\hline $\mathrm{b} / \AA ̊$ & $13.1385(2)$ \\
\hline$c / \AA$ & $13.6483(2)$ \\
\hline$\alpha /^{\circ}$ & 90 \\
\hline$\beta /^{\circ}$ & $100.9460(10)$ \\
\hline$y /{ }^{\circ}$ & 90 \\
\hline Volume $/ \AA^{3}$ & $1700.95(5)$ \\
\hline Z & 2 \\
\hline$\rho_{\text {calc }} \mathrm{g} / \mathrm{cm}^{3}$ & 1.206 \\
\hline$\mu / \mathrm{mm}^{-1}$ & 0.575 \\
\hline$F(000)$ & 668.0 \\
\hline Crystal size $/ \mathrm{mm}^{3}$ & $0.2 \times 0.1 \times 0.05$ \\
\hline Radiation & CuKa $(\lambda=1.54178)$ \\
\hline \multicolumn{2}{|c|}{$2 \Theta$ range for data collection $/{ }^{\circ} 6.596$ to 139.332} \\
\hline Index ranges & $-10 \leq h \leq 11,-15 \leq k \leq 15,-16 \leq \mathrm{I} \leq 16$ \\
\hline Reflections collected & 23828 \\
\hline Independent reflections & $6223\left[R_{\text {int }}=0.0263, R_{\text {sigma }}=0.0250\right]$ \\
\hline Data/restraints/parameters & $6223 / 1 / 424$ \\
\hline Goodness-of-fit on $F^{2}$ & 1.036 \\
\hline Final $R$ indexes $[\mid>=2 \sigma(I)]$ & $\mathrm{R}_{1}=0.0263, \mathrm{wR}_{2}=0.0682$ \\
\hline Final $\mathrm{R}$ indexes [all data] & $\mathrm{R}_{1}=0.0266, \mathrm{wR}_{2}=0.0685$ \\
\hline \multicolumn{2}{|c|}{ Largest diff. peak/hole / e $\AA^{-3} 0.17 /-0.16$} \\
\hline Flack parameter & $0.03(4)$ \\
\hline
\end{tabular}

Table S3. Crystal structure and refinement data for Lact-2 (\#CCDC: 1999855). 


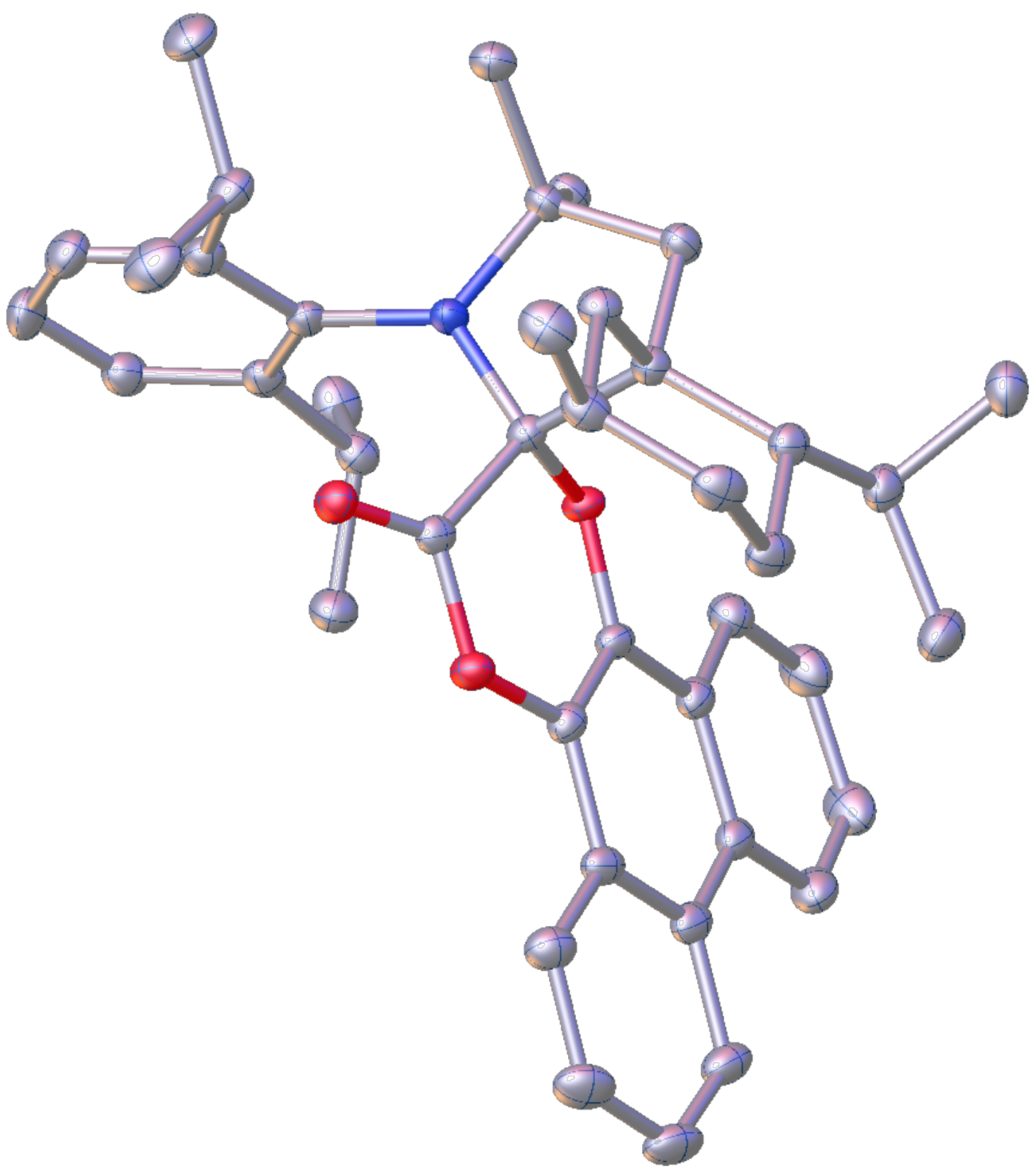

Fig. S17. X-ray structure of Lact-2 (Ellipsoids shown at 30\% probability; Hydrogen atoms have been omitted for clarity). 
S3.3. X-Ray data and structure for Carbo-1.

\begin{tabular}{|c|c|}
\hline Identification code & Carbo-1 \\
\hline Empirical formula & $\mathrm{C}_{15} \mathrm{H}_{8} \mathrm{O}_{3}$ \\
\hline Formula weight & 236.21 \\
\hline Temperature/K & 100.0 \\
\hline Crystal system & monoclinic \\
\hline Space group & $\mathrm{P} 22_{1} / \mathrm{c}$ \\
\hline$a / \AA$ & $15.818(19)$ \\
\hline $\mathrm{b} / \AA \AA$ & $7.181(6)$ \\
\hline$c / \AA$ & $18.43(2)$ \\
\hline$\alpha /^{\circ}$ & 90 \\
\hline$\beta /^{\circ}$ & $97.14(5)$ \\
\hline $\mathrm{y} /{ }^{\circ}$ & 90 \\
\hline Volume/ $\AA^{3}$ & $2077(4)$ \\
\hline Z & 8 \\
\hline$\rho_{\text {calc }} \mathrm{g} / \mathrm{cm}^{3}$ & 1.511 \\
\hline$\mu / \mathrm{mm}^{-1}$ & 0.106 \\
\hline$F(000)$ & 976.0 \\
\hline Crystal size $/ \mathrm{mm}^{3}$ & $0.3 \times 0.05 \times 0.05$ \\
\hline Radiation & $\operatorname{MoKa}(\lambda=0.71073)$ \\
\hline \multicolumn{2}{|c|}{$2 \Theta$ range for data collection $/{ }^{\circ} 2.594$ to 50.724} \\
\hline Index ranges & $-12 \leq \mathrm{h} \leq 19,-8 \leq \mathrm{k} \leq 8,-22 \leq \mathrm{I} \leq 21$ \\
\hline Reflections collected & 11759 \\
\hline Independent reflections & $3783\left[R_{\text {int }}=0.0501, R_{\text {sigma }}=0.0595\right]$ \\
\hline Data/restraints/parameters & $3783 / 0 / 325$ \\
\hline Goodness-of-fit on $\mathrm{F}^{2}$ & 1.036 \\
\hline Final $R$ indexes $[I>=2 \sigma(I)]$ & $\mathrm{R}_{1}=0.0828, w \mathrm{R}_{2}=0.2192$ \\
\hline Final $R$ indexes [all data] & $\mathrm{R}_{1}=0.1087, \mathrm{wR}_{2}=0.2400$ \\
\hline Largest diff. peak/hole / e $\AA^{-3}$ & $0.87 /-0.38$ \\
\hline
\end{tabular}

Table S4. Crystal structure and refinement data for Carbo-1 (\#CCDC: 1999854). 


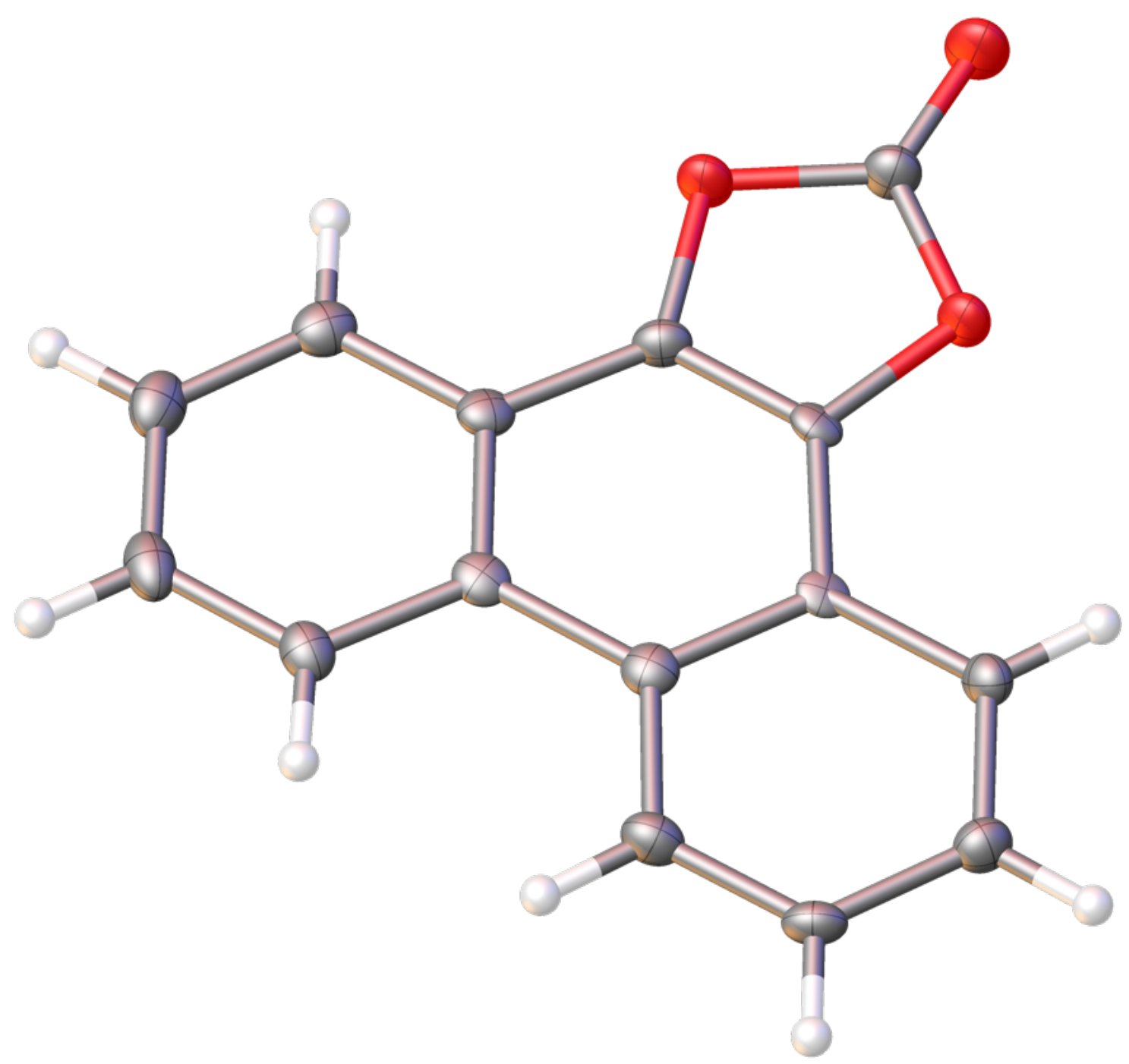

Fig. S18. X-ray structure of Carbo-1 (Ellipsoids shown at 30\% probability).

\# start Validation Reply Form

_vrf_PLAT097_Carbo-1

;

PROBLEM: Large Reported Max. (Positive) Residual Density $\quad 0.87$ eA-3

RESPONSE: Residual electron density was detected which can be attributed to a secondary orientation of Carbo-1 in the lattice.

;

\# end Validation Reply Form 
S3.4. X-Ray data and structure for I.

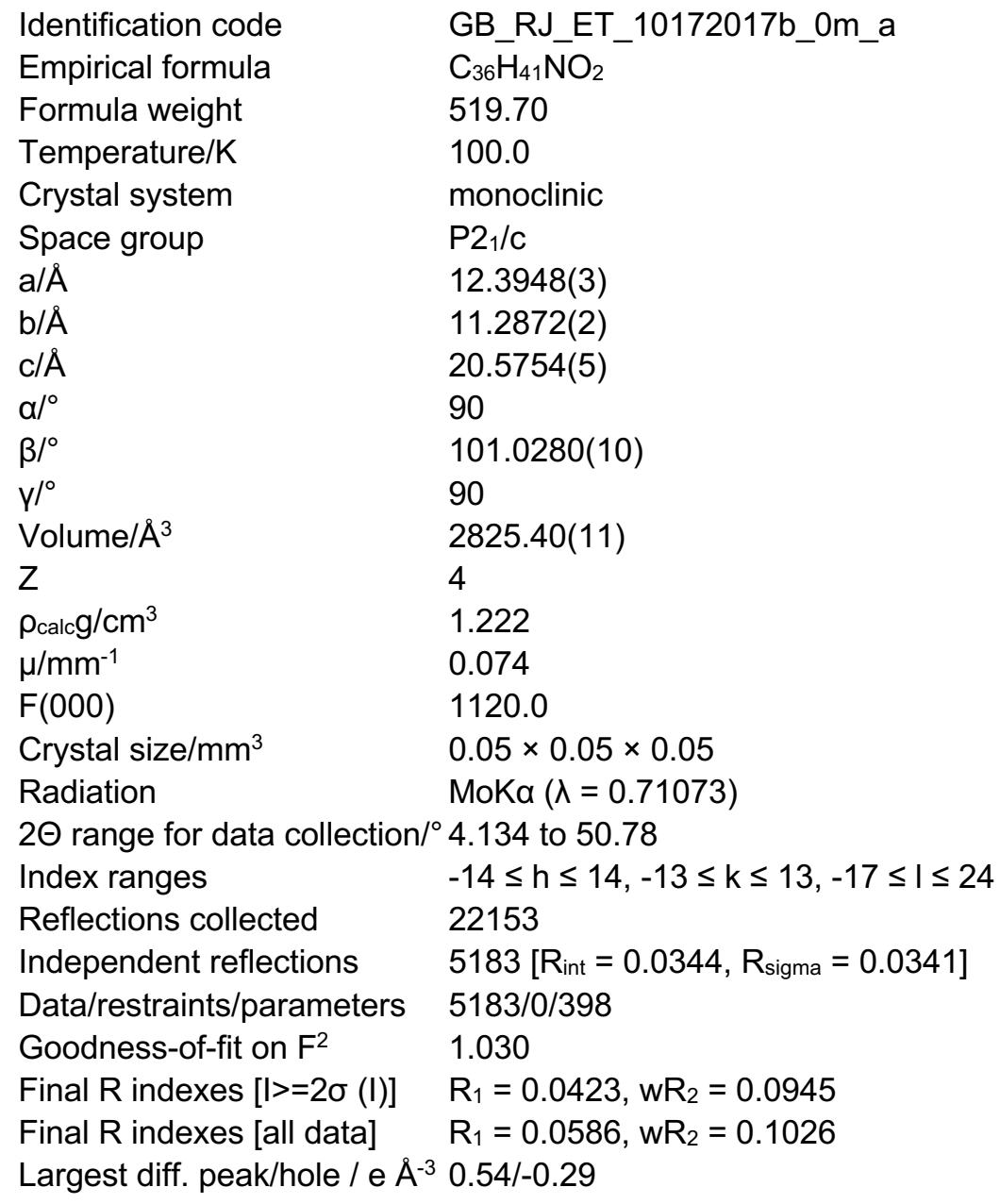

Table S5. Crystal structure and refinement data for I (\#CCDC: 1999857). 


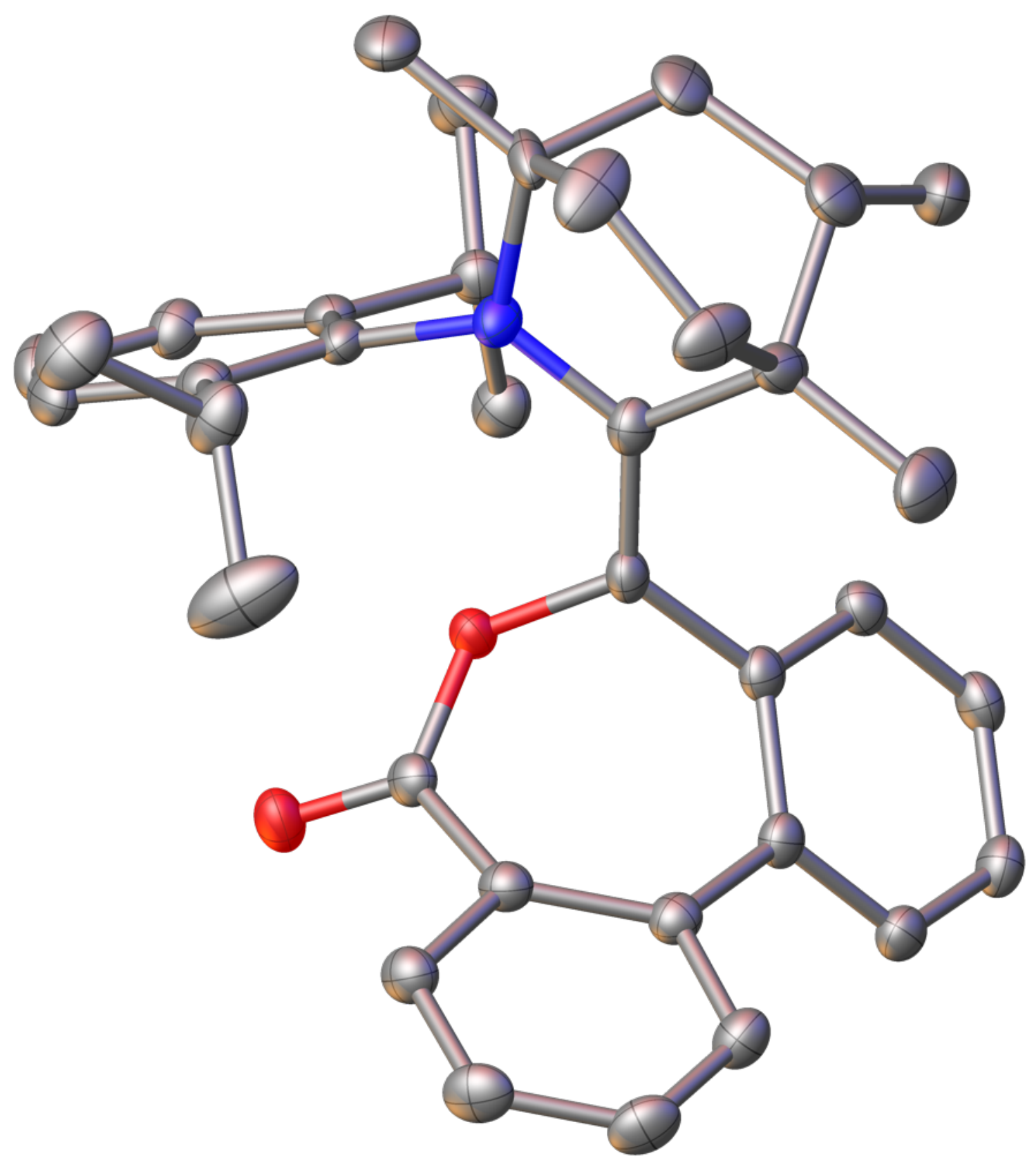

Fig. S19. X-ray structure of I (Ellipsoids shown at 30\% probability; Hydrogen atoms have been omitted for clarity). 
S3.5. X-Ray data and structure for II.

\begin{tabular}{|c|c|}
\hline Identification code & II \\
\hline Empirical formula & $\mathrm{C}_{34} \mathrm{H}_{39} \mathrm{NO}_{2}$ \\
\hline Formula weight & 493.66 \\
\hline Temperature/K & 100.15 \\
\hline Crystal system & monoclinic \\
\hline Space group & $\mathrm{P} 2{ }_{1} / \mathrm{n}$ \\
\hline$a / \AA ̊$ & $10.042(3)$ \\
\hline $\mathrm{b} / \AA$ & $13.464(3)$ \\
\hline$c / \AA ̊$ & $20.119(5)$ \\
\hline$\alpha /^{\circ}$ & 90 \\
\hline$\beta /^{\circ}$ & $90.293(9)$ \\
\hline $\mathrm{y} /{ }^{\circ}$ & 90 \\
\hline Volume/ $/ \AA^{3}$ & 2720.3(12) \\
\hline Z & 4 \\
\hline$\rho_{\text {calc }} \mathrm{g} / \mathrm{cm}^{3}$ & 1.205 \\
\hline$\mu / \mathrm{mm}^{-1}$ & 0.074 \\
\hline$F(000)$ & 1064.0 \\
\hline Crystal size $/ \mathrm{mm}^{3}$ & $0.25 \times 0.2 \times 0.1$ \\
\hline Radiation & $\operatorname{MoKa}(\lambda=0.71073)$ \\
\hline \multicolumn{2}{|c|}{$2 \Theta$ range for data collection $/{ }^{\circ} 3.64$ to 52.048} \\
\hline Index ranges & $-12 \leq \mathrm{h} \leq 12,-16 \leq \mathrm{k} \leq 16,-24 \leq \mathrm{I} \leq 24$ \\
\hline Reflections collected & 40418 \\
\hline Independent reflections & $5351\left[R_{\text {int }}=0.0780, R_{\text {sigma }}=0.0461\right]$ \\
\hline Data/restraints/parameters & $5351 / 0 / 343$ \\
\hline Goodness-of-fit on $\mathrm{F}^{2}$ & 1.045 \\
\hline Final $R$ indexes $[l>=2 \sigma(I)]$ & $\mathrm{R}_{1}=0.0418, w \mathrm{R}_{2}=0.1007$ \\
\hline Final $\mathrm{R}$ indexes [all data] & $\mathrm{R}_{1}=0.0569, w \mathrm{R}_{2}=0.1108$ \\
\hline Largest diff. peak/hole / e $\AA^{-3}$ & $0.28 /-0.23$ \\
\hline
\end{tabular}

Table S6. Crystal structure and refinement data for II (\#CCDC: 1999856). 


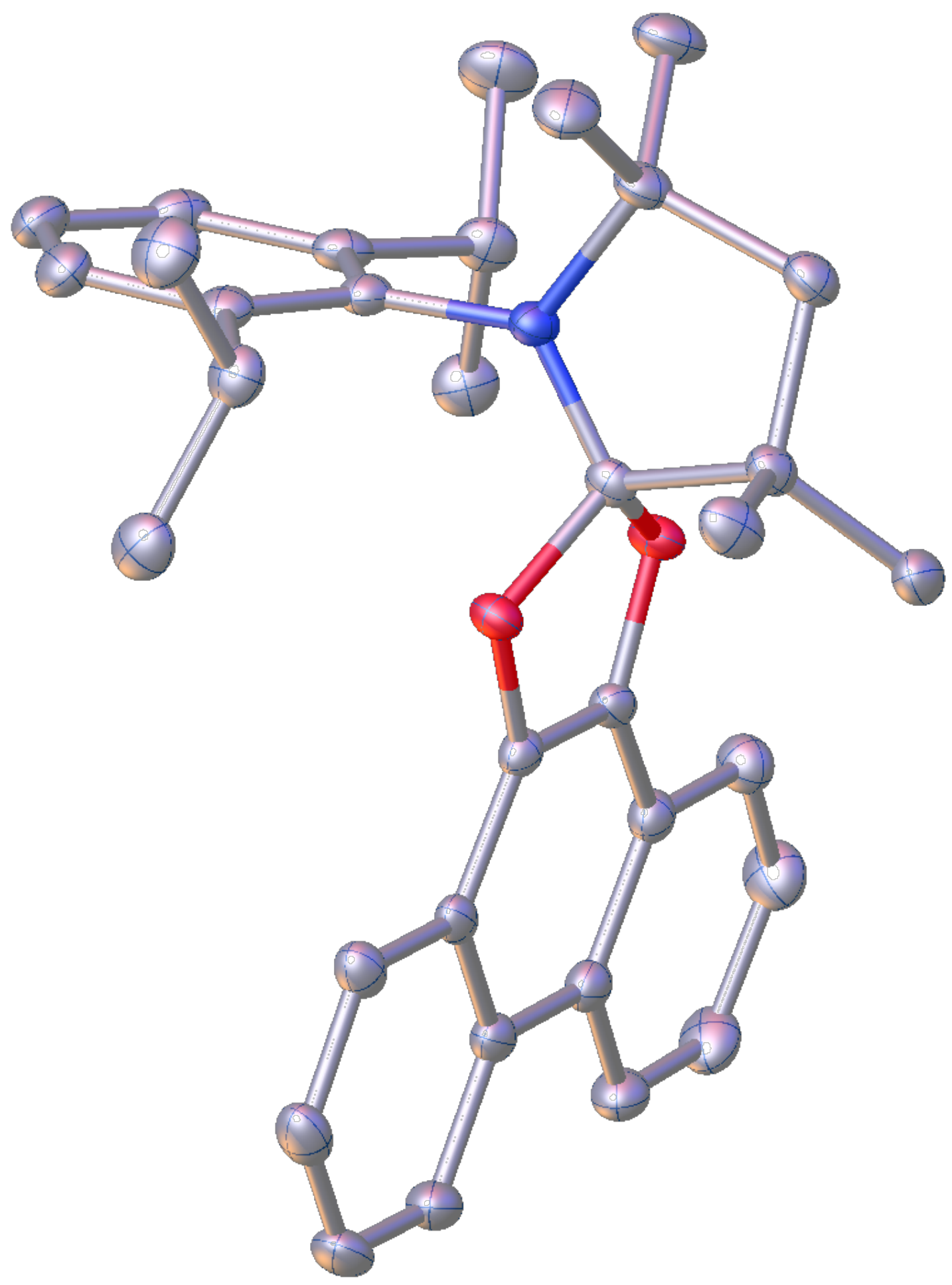

Fig. S20. X-ray structure of II (Ellipsoid shown at 30\% probability; Hydrogen atoms have been omitted for clarity). 


\section{S4. Computational details.}

All calculations were performed with the Gaussian16 program package ${ }^{8}$ (version g16, rev.a03). The theoretical approach is based on the framework of density functional theory (DFT) ${ }^{9,10}$ All calculations were performed with the B3LYP functional and a triple- $\zeta$ basis set [TZVP]. ${ }^{11,12}$ Grimme's D3 dispersion correction with Becke-Johnson damping was used in order to take dispersion effects into account. ${ }^{13,14}$ Ground states were fully optimized without constraints at the corresponding level of theory and verified by a frequency calculation. Gibbs free reaction energies and enthalpies were calculated for standard conditions ( $p=1 \mathrm{~atm}, T=298 \mathrm{~K}$ ) and are unscaled. For the visualization of molecular structures, CYLview ${ }^{15}$ was used.

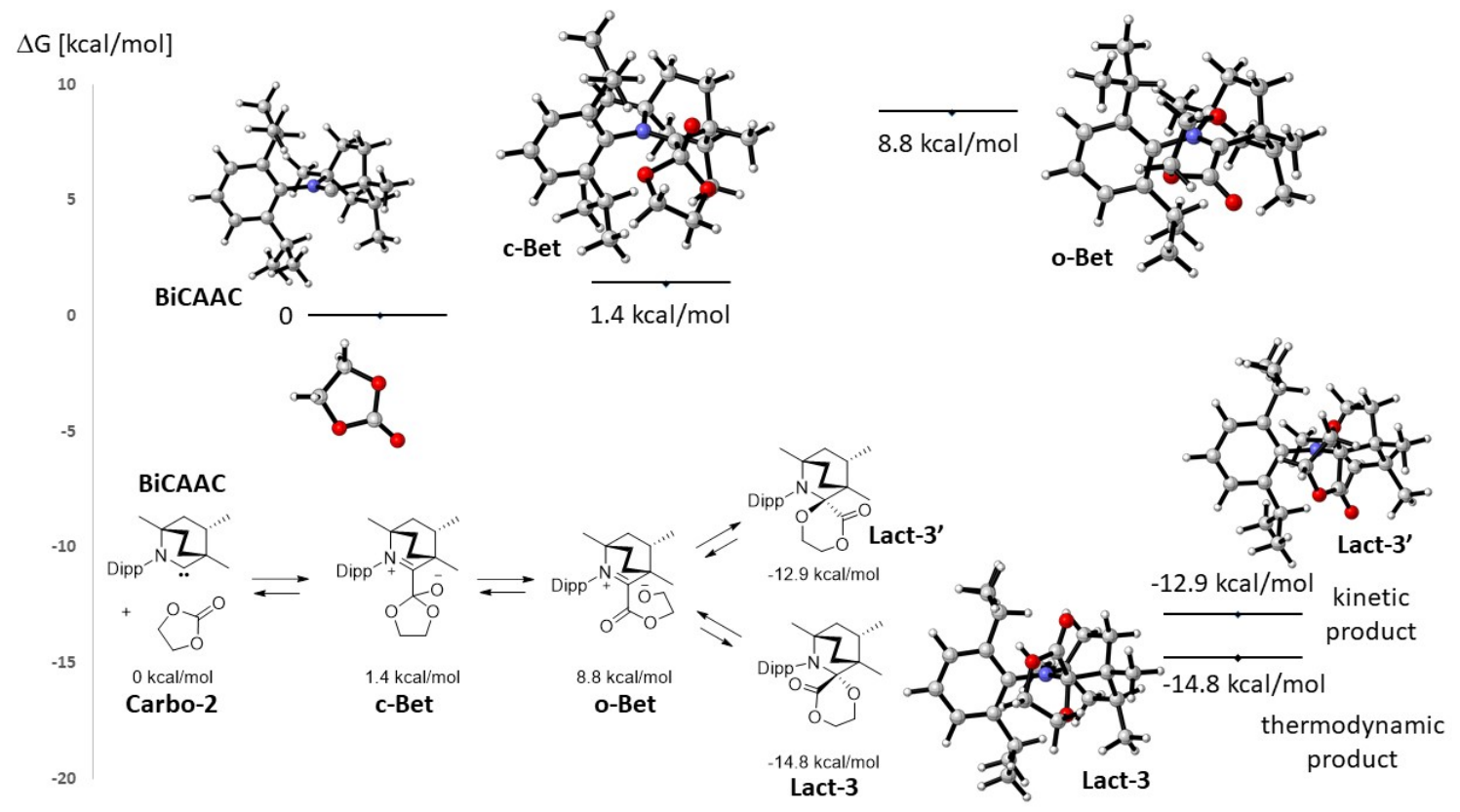

Fig. S21. Energy profile for the reversible carbonate activation.

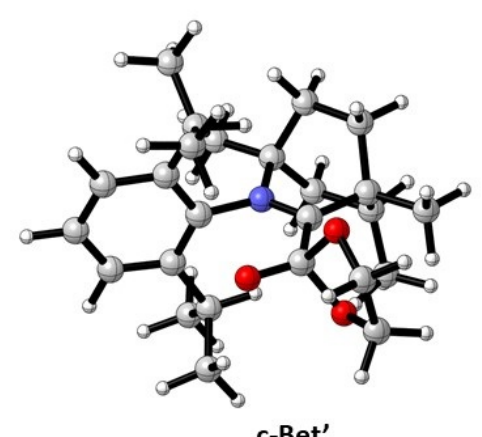

c-Bet'

$4.0 \mathrm{kcal} / \mathrm{mol}$

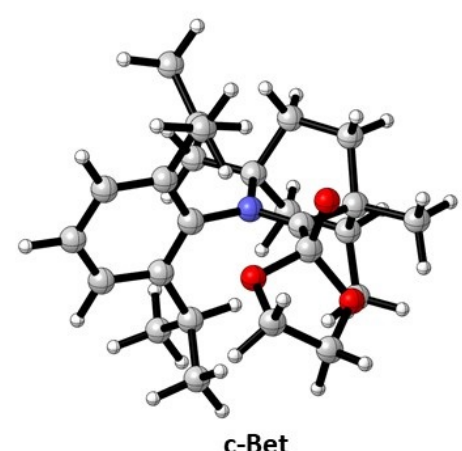

c-Bet

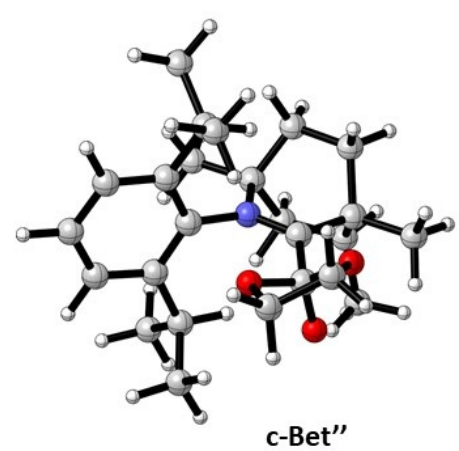

$0.1 \mathrm{kcal} / \mathrm{mol}$

Fig. S22. Relative energy comparison between different conformers for the carbonate addition product. 


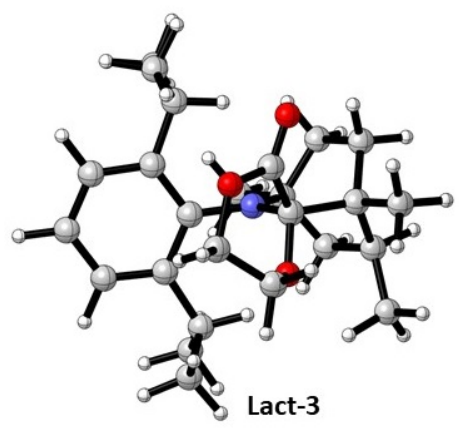

$0 \mathrm{kcal} / \mathrm{mol}$

(thermodynamic product)

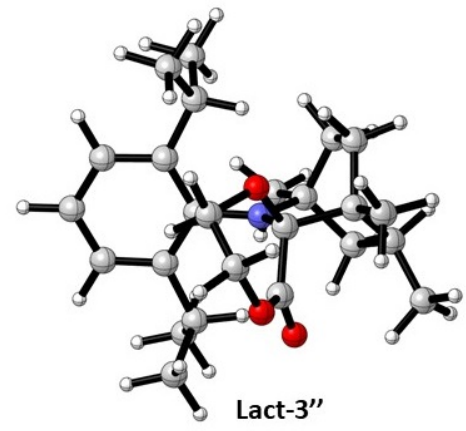

$+2.3 \mathrm{kcal} / \mathrm{mol}$

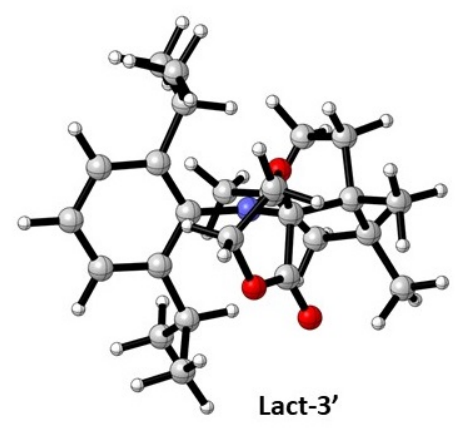

+1.9 kcal $/ \mathrm{mol}$ (kinetic product)

Fig. S23. Relative energy comparison between different diastereomers and conformers for the formal 1,2-shift products.

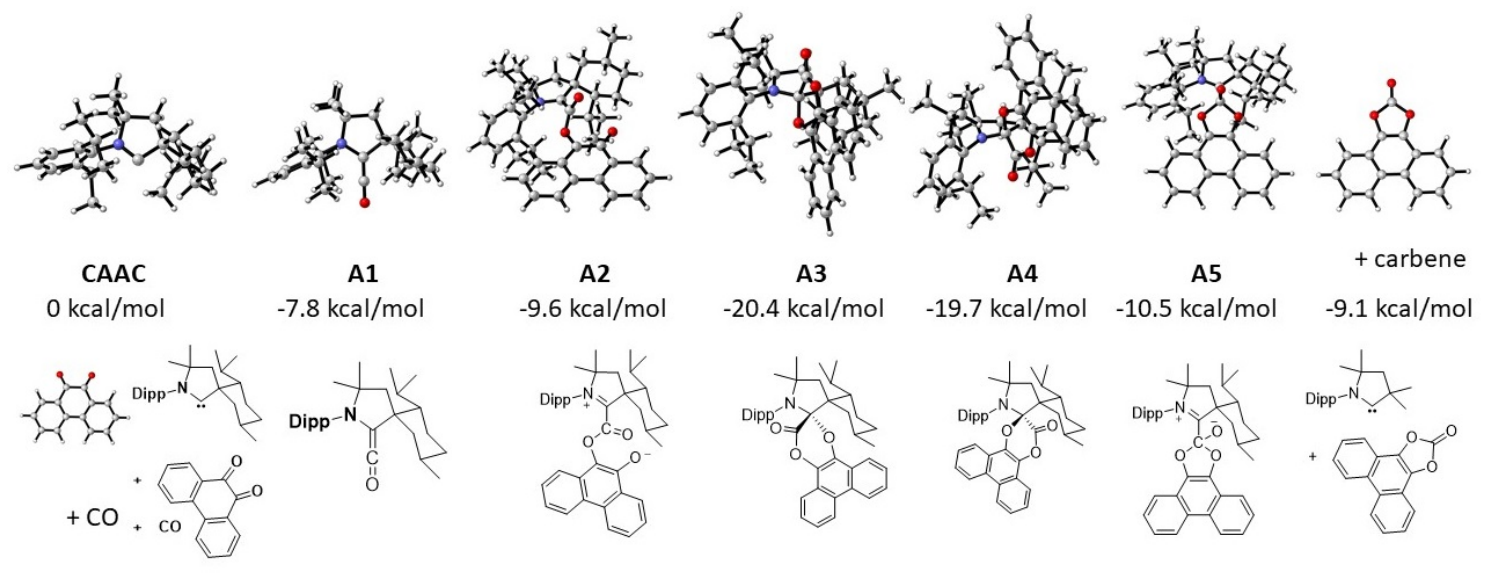

Fig. S24. Reaction profile for the Quin to Carbo-1 transformation with CAAC.

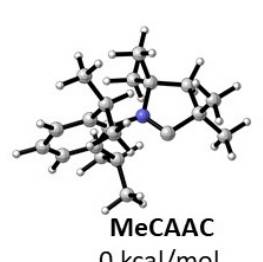

$0 \mathrm{kcal} / \mathrm{mol}$
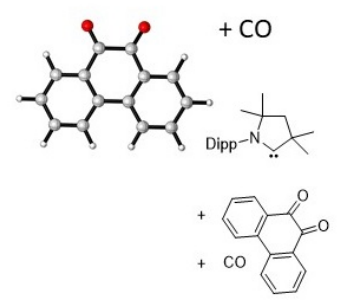
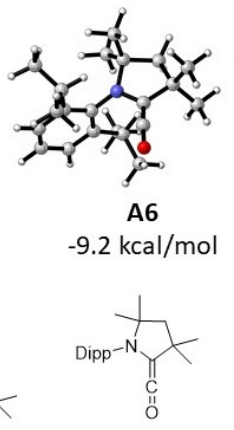

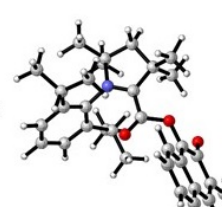

A7
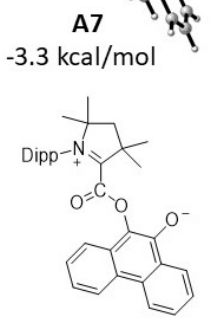

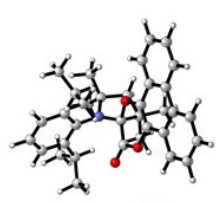

$-31.1 \mathrm{kcal} / \mathrm{mol}$

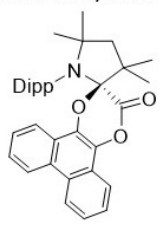

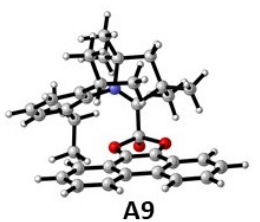

$-8.9 \mathrm{kcal} / \mathrm{mol}$

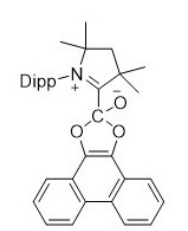

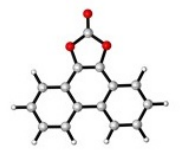

+ carbene

$-9.1 \mathrm{kcal} / \mathrm{mol}$

Dipp-N

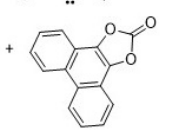

Fig. S25. Reaction profile for the Quin to Carbo-1 transformation with CAACMe . 


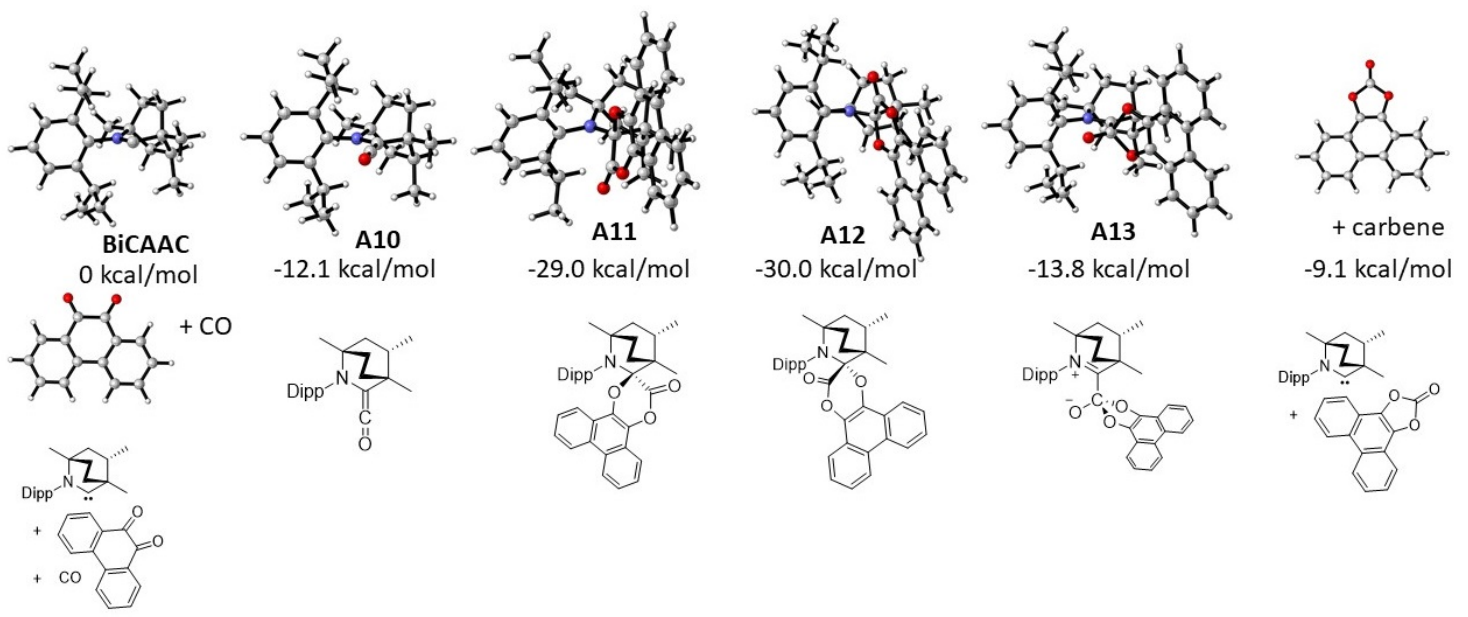

Fig. S26. Reaction profile for the Quin to Carbo-1 transformation with BiCAAC.

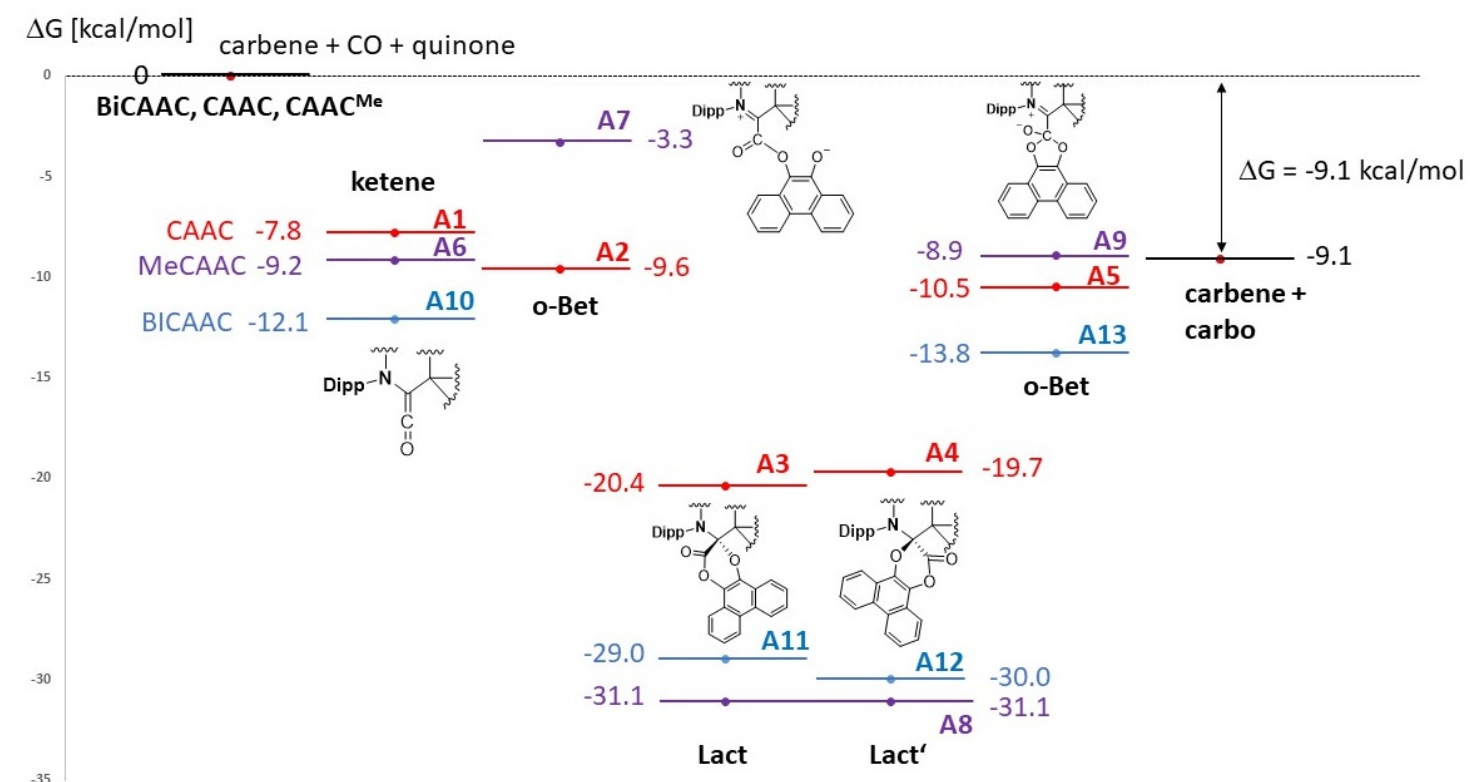

Fig. S27. Reaction profile for the CO fixation employing different carbenes. 


\section{BiCAAC}

56

scf done: -913.341131

\begin{tabular}{|c|c|c|c|}
\hline & 574 & 030 & 87 \\
\hline & 0.947388 & 340129 & .40199 \\
\hline & 318404 & 151372 & 035898 \\
\hline & 1.006760 & .398494 & 053668 \\
\hline & 78 & 0 & 60 \\
\hline & 2.213460 & 138063 & 7960 \\
\hline & 3.11 & 208491 & 674 \\
\hline & 2.216322 & 2 & 046 \\
\hline & -1.081837 & 3215 & 1980 \\
\hline & -2.043667 & -0.799510 & 3366 \\
\hline & -3.38 & 971 & 13 \\
\hline & -3.761439 & 0.907236 & -0.233489 \\
\hline & -2.790112 & 1.895607 & 684 \\
\hline & -1.437617 & 1.569693 & -0.08821 \\
\hline & -1.677539 & 86 & -0.20411 \\
\hline & . & 1 & $\cdot$ \\
\hline & -0.385026 & 2.660748 & -0.127273 \\
\hline & -4 & 4 & 1.00 \\
\hline & 0.004725 & 3751 & .537537 \\
\hline & 0.4152 & 0 & -0.564558 \\
\hline & 3.208352 & 6 & 03 \\
\hline & -0.751761 & 3.902797 & .689011 \\
\hline & -1.961135 & & .1.. \\
\hline & 4.041781 & -0.249965 & .552745 \\
\hline & 2.14416 & 8 & 2.050111 \\
\hline & & & 1.431057 \\
\hline & 2.020760 & 32 & 12 \\
\hline & 然 & 8 & 90 \\
\hline & 1.700188 & 8 & -0 \\
\hline & 8 & -2.5 & 31 \\
\hline & -0.897218 & -0.597276 & \\
\hline
\end{tabular}

\begin{tabular}{llll} 
H & 0.514209 & -0.159174 & 3.487728 \\
H & -0.296788 & 1.060498 & 2.500158 \\
H & 3.239931 & -0.373899 & -2.617957 \\
H & 4.233846 & -1.497677 & -1.669824 \\
H & 2.740682 & -2.047499 & -2.450999 \\
H & 3.933711 & 2.209140 & 0.112424 \\
H & 4.193142 & 1.283280 & -1.363957 \\
H & 2.596492 & 1.942110 & -1.010232 \\
H & -3.087994 & 2.935330 & -0.182116 \\
H & -4.808600 & 1.178279 & -0.288349 \\
H & -4.146227 & -1.192590 & -0.334297 \\
H & 0.526785 & 2.253223 & 0.300244 \\
H & 0.722230 & 3.768138 & -1.639695 \\
H & 0.243331 & 2.132055 & -2.138920 \\
\hline H & -0.958192 & 3.429345 & -2.079658 \\
H & 0.093544 & 4.593627 & 0.714958 \\
\hline H & -1.011487 & 3.643733 & 1.717554 \\
H & -1.595912 & 4.442380 & 0.255553 \\
H & -0.606896 & -2.357189 & -0.132168 \\
H & -2.029647 & -4.159690 & 0.717551 \\
H & -2.155919 & -2.757480 & 1.787877 \\
H & -3.455459 & -3.126445 & 0.655329 \\
H & -1.651191 & -3.830804 & -1.793982 \\
H & -1.412769 & -2.196101 & -2.435155 \\
H & -3.025823 & -2.728990 & -1.937969 \\
\hline & & & \\
\hline
\end{tabular}

Carbo-2

10

scf done: $-\mathbf{3 4 2 . 5 3 6 7 1 7}$

$\begin{array}{llll}\text { O } & -0.056936 & 0.231677 & 0.055744 \\ \text { C } & -0.058718 & -0.132878 & 1.445711 \\ \text { C } & 1.425067 & -0.084350 & 1.805073 \\ \text { O } & 2.062577 & -0.284119 & 0.532854 \\ \text { C } & 1.184566 & 0.020607 & -0.462209 \\ \text { O } & 1.461326 & 0.091956 & -1.614666\end{array}$




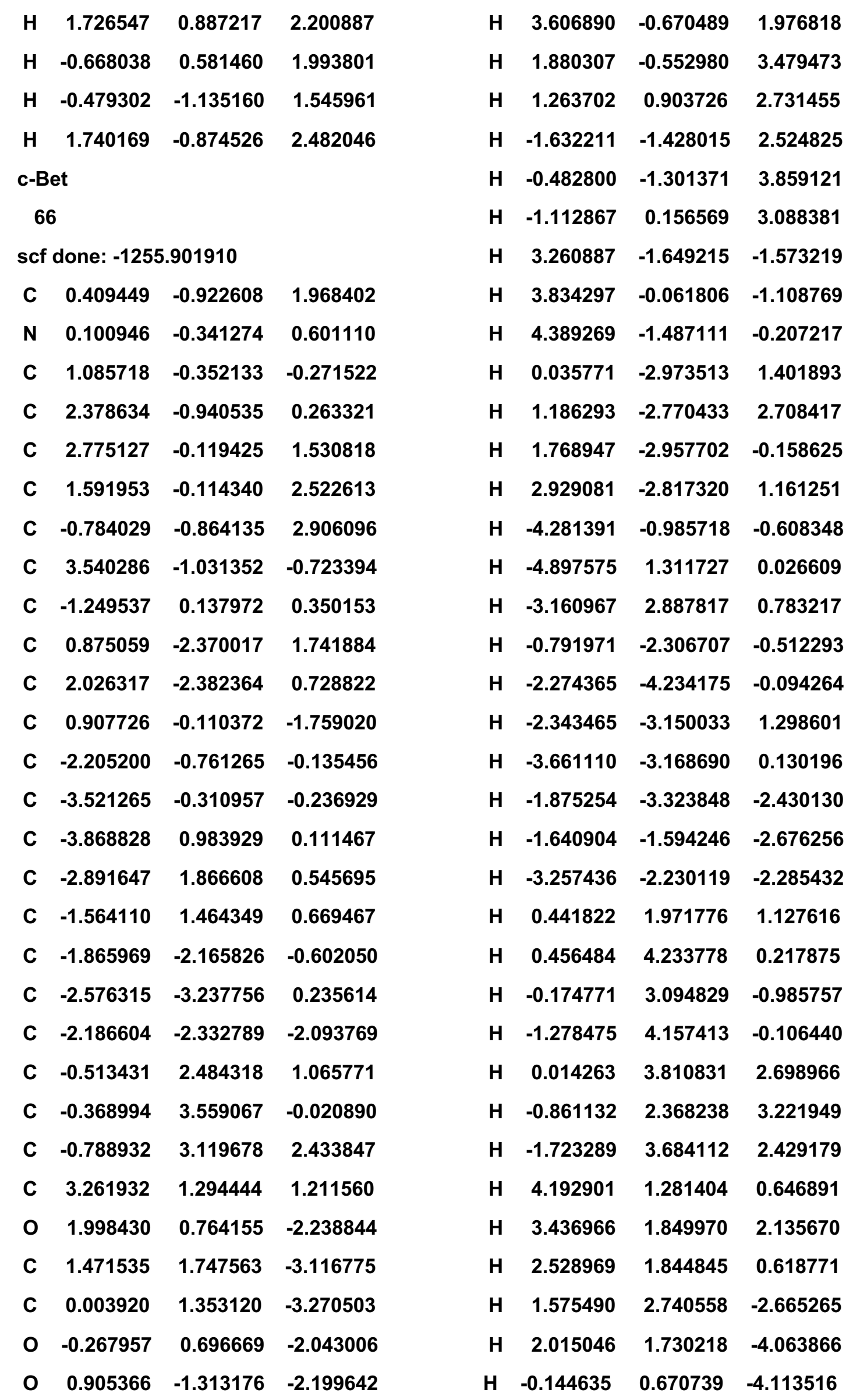




\begin{tabular}{|c|c|c|c|c|c|c|c|}
\hline $\mathbf{H}$ & -0.672891 & 2.201626 & -3.364931 & $\mathbf{H}$ & -2.368955 & 0.238507 & 2.388262 \\
\hline \multicolumn{4}{|c|}{ c-Bet' } & $\mathbf{H}$ & -1.643204 & 4160 & .490404 \\
\hline \multicolumn{4}{|c|}{66} & $\mathbf{H}$ & -2.065578 & 1.883461 & 1.840067 \\
\hline \multicolumn{4}{|c|}{ scf done: -1255.894691} & $\mathbf{H}$ & 3.527007 & -1.528247 & 0.603248 \\
\hline C & -0.265268 & 0.681135 & 2.053290 & $\mathbf{H}$ & 3.848344 & 0.066727 & -0.064830 \\
\hline $\mathbf{N}$ & -0.175298 & 0.170735 & 0.626801 & $\mathbf{H}$ & 4.185419 & -0.251219 & 1.643695 \\
\hline C & 1.004960 & -0.169265 & 0.201616 & $\mathbf{H}$ & -0.434676 & -1.261002 & 2.990745 \\
\hline C & 2.103176 & -0.024360 & 1.228842 & $\mathbf{H}$ & 0.354260 & -0.035998 & 3.964862 \\
\hline C & 2.116671 & 1.466422 & 1.711872 & $\mathbf{H}$ & 1.616766 & -1.940807 & 2.106654 \\
\hline C & 0.692269 & 1.877840 & 2.127866 & $\mathbf{H}$ & 2.413850 & -0.826021 & 3.203459 \\
\hline C & -1.676350 & 1.074554 & 2.454078 & $\mathbf{H}$ & -4.099196 & -1.942054 & -0.455504 \\
\hline C & 3.504192 & -0.463261 & 0.815589 & $\mathbf{H}$ & -4.984236 & 0.069747 & -1.567812 \\
\hline C & -1.425245 & 0.081990 & -0.130597 & $\mathbf{H}$ & -3.543309 & 2.046636 & -1.864270 \\
\hline C & 0.280218 & -0.440938 & 2.954471 & $\mathbf{H}$ & -0.649303 & -2.166631 & 0.978656 \\
\hline C & 1.645417 & -0.900939 & 2.432843 & $\mathbf{H}$ & -2.040131 & -3.817108 & 2.141346 \\
\hline C & 1.155601 & -0.707604 & -1.262893 & $\mathbf{H}$ & -2.627605 & -2.193204 & 2.524001 \\
\hline C & -2.193902 & -1.078005 & -0.000530 & $\mathbf{H}$ & -3.496895 & -3.198956 & 1.368382 \\
\hline C & -3.482509 & -1.055670 & -0.529240 & $\mathbf{H}$ & -0.963428 & -4.297658 & -0.149622 \\
\hline C & -3.978313 & 0.071416 & -1.166983 & $\mathbf{H}$ & -0.839950 & -2.981417 & -1.336557 \\
\hline C & -3.170195 & 1.187788 & -1.321431 & $\mathbf{H}$ & -2.418072 & -3.700467 & -0.960049 \\
\hline C & -1.874925 & 1.216887 & -0.810635 & $\mathbf{H}$ & -0.034224 & 2.251074 & -0.580863 \\
\hline C & -1.641012 & -2.367441 & 0.577653 & $\mathbf{H}$ & 0.096826 & 3.224696 & -2.806078 \\
\hline C & -2.501349 & -2.921356 & 1.719506 & $\mathbf{H}$ & -0.213685 & 1.477235 & -2.910159 \\
\hline C & -1.453470 & -3.403219 & -0.541865 & $\mathbf{H}$ & -1.524155 & 2.638610 & -3.201753 \\
\hline C & -0.973987 & 2.400560 & -1.107203 & $\mathbf{H}$ & -0.861786 & 4.547435 & -0.826515 \\
\hline C & -0.631845 & 2.435494 & -2.604795 & $\mathbf{H}$ & -1.781800 & 3.723703 & 0.438460 \\
\hline C & -1.563478 & 3.733383 & -0.631837 & H & -2.492191 & 3.967540 & -1.155503 \\
\hline C & 2.710098 & 2.437413 & 0.691122 & H & 3.769504 & 2.249116 & 0.522449 \\
\hline 0 & 1.872457 & -1.986880 & -1.057511 & H & 2.607196 & 3.462829 & 1.053201 \\
\hline C & 2.696075 & -2.126209 & -2.204733 & H & 2.207928 & 2.359193 & -0.273884 \\
\hline C & 3.124491 & -0.681704 & -2.548224 & H & 3.539199 & -2.770756 & -1.953272 \\
\hline 0 & 2.247687 & 0.154480 & -1.806672 & H & 2.130309 & -2.575068 & -3.026077 \\
\hline 0 & 0.113792 & -0.757857 & -1.952091 & $\mathbf{H}$ & 3.029569 & -0.478471 & -3.617937 \\
\hline $\mathbf{H}$ & 2.758186 & 1.465223 & 2.597410 & H & 4.155516 & -0.476868 & -2.243415 \\
\hline $\mathbf{H}$ & 0.675290 & .260707 & 3.149408 & & & & \\
\hline H & 0.314886 & 2.672823 & 1.485292 & & & & \\
\hline
\end{tabular}


scf done: -1255.901947

\begin{tabular}{|c|c|c|c|}
\hline C & 0.616416 & 0.979623 & 1.875338 \\
\hline $\mathbf{N}$ & 0.165173 & 0.279303 & 0.606889 \\
\hline C & 1.077192 & -0.427056 & -0.023913 \\
\hline & 2.416318 & -0.479899 & 0.683511 \\
\hline & 2.944236 & 0.982734 & 0.898471 \\
\hline & 1.809348 & 1.851638 & 1.468658 \\
\hline & -0.489865 & 1.805318 & 2.508547 \\
\hline C & 3.490034 & -1.343623 & 0.028796 \\
\hline & -1.219921 & 0.437766 & 0.196387 \\
\hline & 1.119953 & -0.112105 & 2.837758 \\
\hline & 2.086656 & -1.044516 & 2.095024 \\
\hline & 0.913985 & -0.959303 & -1.438777 \\
\hline & -2.173433 & -0.448565 & 0.710403 \\
\hline & -3.512890 & -0.201395 & 0.419201 \\
\hline & -3.886431 & 0.880668 & -0.363605 \\
\hline & -2.916219 & 1.713684 & -0.897105 \\
\hline & -1.561709 & 1.506156 & -0.638997 \\
\hline & -1.799746 & -1.692024 & 1.496874 \\
\hline & -2.439141 & -1.720388 & 2.890610 \\
\hline & -2.154685 & -2.956860 & 0.702059 \\
\hline & -0.530377 & 2.389421 & -1.318053 \\
\hline & -0.622074 & 2.251347 & -2.843995 \\
\hline & -0.649713 & 7828 & -0.889863 \\
\hline & 3.568554 & 623 & 90 \\
\hline & 1.591885 & -0.110657 & -2.116343 \\
\hline C & -0.486311 & -1.113769 & -1.799716 \\
\hline & 1.3 & -2.3581 & -1.474427 \\
\hline C & -0.507689 & -2.114836 & -2.804085 \\
\hline & 0.514260 & -3.129730 & -2.287992 \\
\hline 1 & 3.722102 & 0.017111 & 1.661128 \\
\hline r & 2.144900 & 2.411118 & 2.343818 \\
\hline H & 1.477737 & 2.582002 & 0.1012 \\
\hline & -0.09157 & 2.2554 & 0.780 \\
\hline & 353 & 2.604173 & 1.85383 \\
\hline & -1.352305 & 1.199054 & ( \\
\hline
\end{tabular}

\begin{tabular}{|c|c|c|c|}
\hline H & 4.428112 & -1.190532 & 0.568366 \\
\hline H & 3.225927 & -2.396850 & 0.073141 \\
\hline r & 3.628079 & -1.080937 & -1.015581 \\
\hline & 0.275919 & -0.657645 & 3.256920 \\
\hline r & 1.615128 & 0.392203 & 3.669350 \\
\hline & 1.664465 & -2.044117 & 1.980744 \\
\hline I & 3.027164 & -1.156330 & 2.635900 \\
\hline r & -4.272101 & -0.871543 & 0.801699 \\
\hline F & -4.933146 & 1.061514 & -0.574881 \\
\hline F & -3.210867 & 2.533572 & -1.539086 \\
\hline r & -0.720100 & -1.698101 & 1.62611 \\
\hline H & -2.106214 & -2.601310 & 3.444049 \\
\hline H & -2.177592 & -0.835605 & 3.473578 \\
\hline H & -3.528027 & -1.762278 & 2.825950 \\
\hline $\mathrm{H}$ & -1.801209 & -3.847828 & 1.226119 \\
\hline H & -1.693035 & -2.923851 & -0.282865 \\
\hline $\mathrm{H}$ & -3.234775 & -3.049705 & 0.5710 \\
\hline H & 0.458005 & 2.029222 & -1.04598 \\
\hline H & 0.171066 & 2.834439 & -3.3163 \\
\hline H & -0.491911 & 1.210687 & -3.1317 \\
\hline H & -1.581188 & 2.615289 & -3.220328 \\
\hline H & 0.128245 & 4.453699 & -1.3718 \\
\hline H & -0.545298 & 3.980394 & 0.189 \\
\hline H & -1.615733 & 4.278122 & -1.17768 \\
\hline H & 4.483915 & 1.108762 & -0.637210 \\
\hline H & 3.821785 & 2.661505 & $-0.128 c$ \\
\hline H & 2.879420 & 1.577940 & -1.183381 \\
\hline H & -1.520909 & -2.508719 & -2.8754 \\
\hline H & -0.208563 & -1.696693 & -3.770 \\
\hline & 1.076627 & -3.605414 & -3.09454 \\
\hline H & 0.039786 & -3.907255 & -1.6798 \\
\hline \multicolumn{4}{|c|}{-Bet } \\
\hline & & & \\
\hline
\end{tabular}
scf done: -1255.8899434

$\begin{array}{llll}\text { C } & 0.614226 & 0.257711 & 2.008601 \\ \text { N } & 0.159485 & 0.049620 & 0.578744\end{array}$




\begin{tabular}{|c|c|c|c|c|c|c|c|}
\hline C & 1.047094 & -0.505776 & -0.229162 & $\mathbf{H}$ & 0.066550 & -1.721549 & 2.670762 \\
\hline C & 2.361263 & -0.880682 & 0.442768 & $\mathbf{H}$ & 1.380158 & -0.983957 & 3.566634 \\
\hline C & 2.969749 & 0.413901 & 1.071506 & $\mathbf{H}$ & 1.567044 & -2.720135 & 1.209038 \\
\hline C & 1.894935 & 1.104944 & 1.925270 & H & 2.899502 & -2.050331 & 2.157932 \\
\hline C & -0.418525 & 0.989702 & 2.849107 & $\mathbf{H}$ & -4.426983 & 0.057661 & 0.415324 \\
\hline C & 3.396026 & -1.595257 & -0.422856 & $\mathbf{H}$ & -4.494274 & 2.368496 & -0.416741 \\
\hline 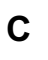 & -1.108220 & 0.628892 & 0.174688 & $\mathbf{H}$ & -2.398472 & 3.521279 & -1.002769 \\
\hline C & 0.969782 & -1.124076 & 2.565065 & $\mathbf{H}$ & -1.322347 & -1.959301 & 0.679465 \\
\hline$C$ & 1.977368 & -1.807255 & 1.628766 & $\mathbf{H}$ & -2.825675 & -2.850829 & 2.482511 \\
\hline$C$ & 0.877430 & -0.503115 & -1.701739 & $\mathbf{H}$ & -2.036266 & -1.370285 & 3.003849 \\
\hline C & -2.291952 & -0.081694 & 0.426563 & $\mathbf{H}$ & -3.717902 & -1.328326 & 2.482014 \\
\hline$C$ & -3.500321 & 0.578359 & 0.217717 & $\mathbf{H}$ & -3.145217 & -3.399689 & 0.051591 \\
\hline C & -3.542502 & 1.876258 & -0.263582 & $\mathbf{H}$ & -3.137197 & -2.083706 & -1.129530 \\
\hline$C$ & -2.363812 & 2.525281 & -0.582097 & $\mathbf{H}$ & -4.328627 & -2.104004 & 0.171737 \\
\hline C & -1.126480 & 1.918988 & -0.373595 & $\mathbf{H}$ & 0.982725 & 2.047473 & -0.558223 \\
\hline C & -2.321598 & -1.548767 & 0.828058 & $\mathbf{H}$ & 1.092850 & 3.341658 & -2.610845 \\
\hline c & -2.743031 & -1.779992 & 2.286394 & H & 0.027537 & 1.954170 & -2.851978 \\
\hline C & -3.289987 & -2.326705 & -0.079615 & H & -0.658469 & 3.566240 & -2.619535 \\
\hline C & 0.123219 & 2.665556 & -0.794775 & $\mathbf{H}$ & 1.232632 & 4.465659 & -0.316462 \\
\hline C & 0.143749 & 2.892650 & -2.312401 & $\mathbf{H}$ & 0.289523 & 3.840123 & 1.041098 \\
\hline C & 0.290449 & 3.988844 & -0.039819 & $\mathbf{H}$ & -0.516671 & 4.683675 & -0.277531 \\
\hline C & 3.618030 & 1.362255 & 0.065426 & H & 4.491099 & 0.910762 & -0.402129 \\
\hline 0 & 1.804640 & -0.309172 & -2.451309 & $\mathbf{H}$ & 3.942103 & 2.276046 & 0.568319 \\
\hline$\sigma$ & -0.406644 & 13 & -2 & $\pi$ & 28 & 01 & 5773 \\
\hline 0 & 0.682565 & -2.609999 & -0.957951 & $\mathbf{H}$ & -1.534322 & -1.870219 & 21117 \\
\hline C & -0.539154 & -1.868533 & -2.879330 & $\mathbf{H}$ & 0.219287 & -1.884570 & -3.663466 \\
\hline C & -0 & 8 & - & $\mathbf{H}$ & 3 & 03 & 674 \\
\hline H & 3.757876 & 0.048294 & 1.734556 & $\mathbf{H}$ & -1.266582 & -3.188384 & -1.334701 \\
\hline H & 2.251852 & 1.276066 & 2.942251 & \multicolumn{4}{|c|}{ Lact-3' } \\
\hline H & 1.642409 & 2.081988 & 1.516447 & \multicolumn{2}{|c|}{66} & & \\
\hline 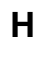 & -0.021351 & 1.076438 & 3.860857 & \multicolumn{4}{|c|}{ scf done: -1255.928403} \\
\hline H & 2 & 27 & 95 & C & 6058 & 63 & 7522 \\
\hline 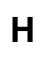 & -1.370142 & 0.472997 & 2.902908 & $\mathbf{N}$ & -0.160699 & 0.101137 & 0.500969 \\
\hline H & 4.270946 & -1.797832 & 0.200210 & 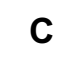 & -1.015509 & 0.372441 & -0.624934 \\
\hline H & 2.985583 & -2.530529 & -0.788219 & C & -2.402722 & 0.881620 & -0.084467 \\
\hline $\mathbf{H}$ & 3.700366 & -1.002011 & -1.276911 & C & -3.098445 & -0.033503 & 0.979576 \\
\hline
\end{tabular}




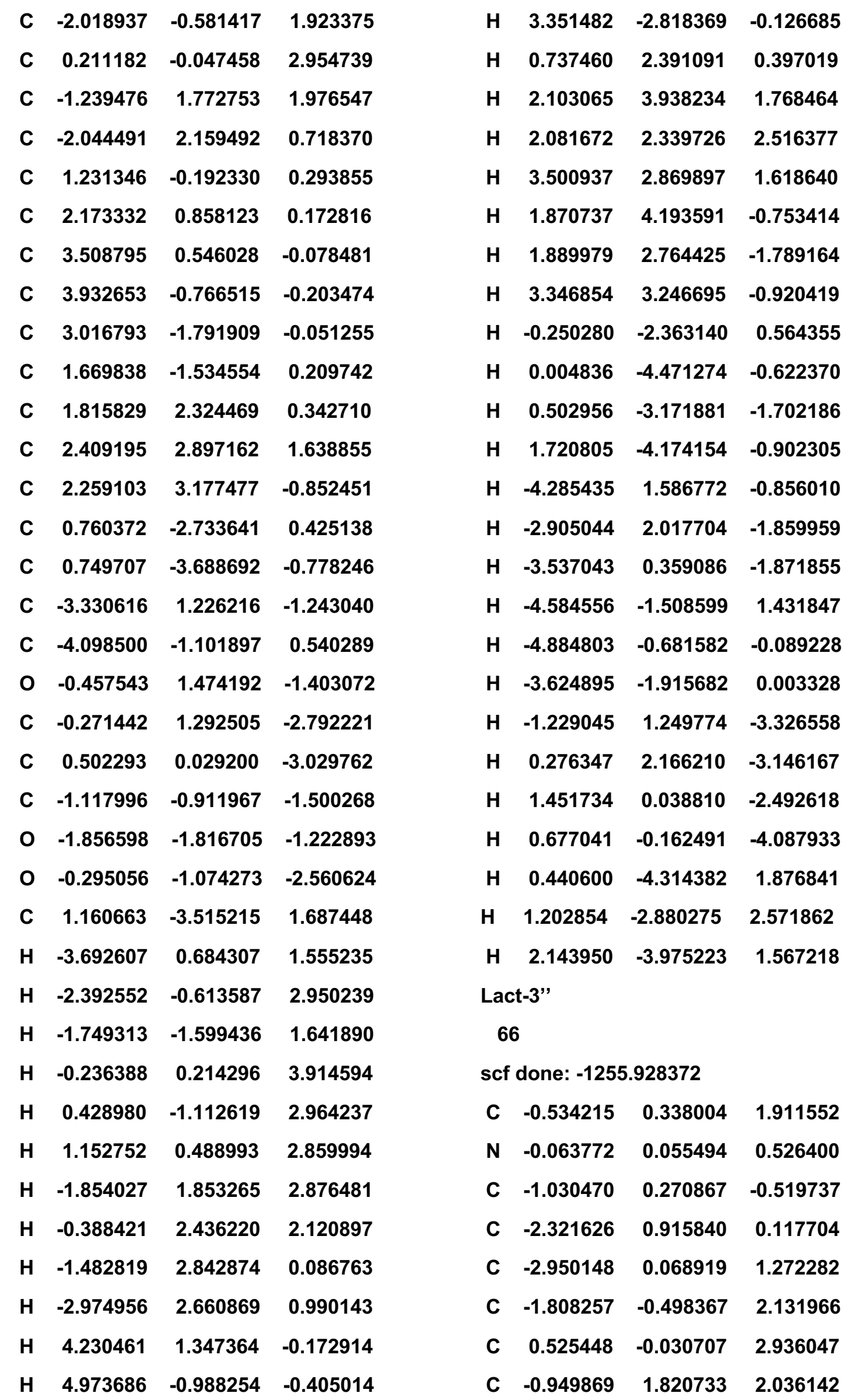




\begin{tabular}{|c|c|c|c|c|c|c|c|}
\hline C & -1.818216 & 2.199453 & 0.819279 & $\mathbf{H}$ & 2.276729 & 2.415289 & 2.228448 \\
\hline C & 1.318770 & -0.155267 & 0.183320 & $\mathbf{H}$ & 3.552914 & 3.036504 & 1.186949 \\
\hline C & 2.181729 & 0.937590 & -0.084615 & $\mathbf{H}$ & 1.675585 & 4.267039 & -0.976240 \\
\hline C & 3.493863 & 0.687573 & -0.483774 & $\mathbf{H}$ & 1.582022 & 2.853010 & -2.024970 \\
\hline C & 3.979507 & -0.602910 & -0.610927 & $\mathbf{H}$ & 3.130963 & 3.344921 & -1.337659 \\
\hline C & 3.151628 & -1.667174 & -0.306260 & $\mathbf{H}$ & 0.038461 & -2.381103 & 0.765924 \\
\hline 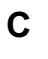 & 1.831161 & -1.471494 & 0.103846 & H & 0.200133 & -4.480040 & -0.459700 \\
\hline C & 1.778205 & 2.390168 & 0.096187 & $\mathbf{H}$ & 0.463450 & -3.159150 & -1.589738 \\
\hline 0 & 2.470410 & 2.996885 & 1.327122 & $\mathbf{H}$ & 1.838892 & -4.099060 & -1.000262 \\
\hline$C$ & 2.061464 & 3.257621 & -1.136034 & $\mathbf{H}$ & -2.930936 & 1.991427 & -1.659359 \\
\hline C & 1.030614 & -2.706728 & 0.473455 & $\mathbf{H}$ & -3.665696 & 0.385896 & -1.521723 \\
\hline C & 0.876990 & -3.663772 & -0.718026 & $\mathbf{H}$ & -4.228367 & 1.700460 & -0.497341 \\
\hline C & -3.341638 & 1.264154 & -0.960525 & $\mathbf{H}$ & -4.409658 & -1.380679 & 1.877079 \\
\hline C & -4.024887 & -0.967375 & 0.940776 & $\mathbf{H}$ & -4.870138 & -0.515376 & 0.419015 \\
\hline 0 & -0.552196 & 1.236580 & -1.484026 & $\mathbf{H}$ & -3.646918 & -1.792535 & 0.345829 \\
\hline C & 0.003758 & 0.709131 & -2.675176 & $\mathbf{H}$ & 0.346950 & 1.559195 & -3.264329 \\
\hline c & -1.060772 & -0.048833 & -3.411580 & $\mathbf{H}$ & 0.863694 & 0.065589 & -2.461444 \\
\hline C & -1.430753 & -1.062194 & -1.236461 & $\mathbf{H}$ & -0.683694 & -0.515922 & -4.321647 \\
\hline 0 & -1.712184 & -2.045703 & -0.609890 & $\mathbf{H}$ & -1.902583 & 0.600361 & -3.659979 \\
\hline 0 & -1.537850 & -1.123884 & -2.583747 & H & 1.018413 & -4.274170 & 1.972682 \\
\hline C & 1.664759 & -3.451365 & 1.658829 & $\mathbf{H}$ & 1.820136 & -2.795144 & 2.515677 \\
\hline 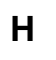 & -3.463815 & 0.825608 & 1.874826 & H & 2.634832 & -3.875840 & 1.390670 \\
\hline H & -2.085852 & -0.477482 & 3.189055 & \multicolumn{4}{|c|}{ Lact-3 } \\
\hline H & -1.605098 & -1.532146 & 1.857442 & \multicolumn{3}{|c|}{66} & \\
\hline H & 1.478093 & 5763 & 2.7 & \multicolumn{4}{|c|}{ scf done: -1255.931464} \\
\hline$n$ & 0.185708 & 0.280569 & 3.924999 & C & -0.704616 & -0.249470 & -1.898815 \\
\hline H & 9 & 6 & 8 & $\mathbf{N}$ & 7 & 40 & 647 \\
\hline $\mathrm{H}$ & -1.509517 & 1.941243 & 2.966918 & C & -1.055884 & -0.435111 & 0.557973 \\
\hline H & -0.076561 & 2.463840 & 2.116436 & 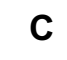 & -2.405266 & -0.930017 & -0.058443 \\
\hline H & -1.266010 & 2.809732 & 0.107423 & C & -3.018147 & 0.187746 & -0.964297 \\
\hline$n$ & -2.689172 & 2.780787 & 1.128295 & C & -1.954594 & 0.638878 & -1.992253 \\
\hline H & 5 & 1 & 24 & C & 36 & 75 & 026 \\
\hline 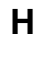 & 5.000725 & -0.775231 & -0.928693 & C & -1.151880 & -1.704257 & -2.123108 \\
\hline H & 3.535900 & -2.676582 & -0.376786 & 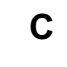 & -2.148781 & -2.112478 & -1.021762 \\
\hline H & 0.709927 & 2.410794 & 0.2 & C & 1.174670 & 0.356756 & -0.258021 \\
\hline H & 2.117463 & 4.016713 & 1.499956 & $C$ & 1.400788 & 1.745616 & -0.094718 \\
\hline
\end{tabular}




\begin{tabular}{|c|c|c|c|c|c|c|c|}
\hline C & 2.697527 & 2.194097 & 0.155732 & $\mathbf{H}$ & 0.474058 & 3.113450 & -2.356722 \\
\hline C & 3.763641 & 1.315173 & 0.243436 & $\mathbf{H}$ & 1.414748 & 4.248237 & -1.393591 \\
\hline$c$ & 3.542545 & -0.038756 & 0.065581 & $\mathbf{H}$ & 1.081339 & -2.265411 & -0.537968 \\
\hline C & 2.266613 & -0.540277 & -0.193976 & $\mathbf{H}$ & 2.716579 & -3.553440 & -1.857602 \\
\hline C & 0.307578 & 2.797598 & -0.193813 & $\mathbf{H}$ & 2.495318 & -1.960594 & -2.583633 \\
\hline C & 0.238791 & 3.679364 & 1.061200 & $\mathbf{H}$ & 3.934975 & -2.297806 & -1.627424 \\
\hline C & 0.476718 & 3.690007 & -1.432491 & $\mathbf{H}$ & -3.021128 & -2.235207 & 1.564058 \\
\hline 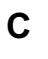 & 2.135670 & -2.038287 & -0.419219 & $\mathbf{H}$ & -3.552962 & -0.555703 & 1.758506 \\
\hline C & 2.860908 & -2.482299 & -1.699321 & $\mathbf{H}$ & -4.345537 & -1.604543 & 0.589030 \\
\hline 0 & -3.381456 & -1.352623 & 1.035935 & $\mathbf{H}$ & -4.189594 & 1.985282 & -1.069353 \\
\hline$C$ & -3.701988 & 1.382304 & -0.298257 & $\mathbf{H}$ & -4.474451 & 1.069701 & 0.406018 \\
\hline$C$ & -1.349394 & 0.778035 & 1.311814 & $\mathbf{H}$ & -2.993520 & 2.011939 & 0.233224 \\
\hline C & -1.138406 & 0.769814 & 2.709682 & $\mathbf{H}$ & -1.265509 & 1.798288 & 3.047367 \\
\hline$C$ & 0.243607 & 0.260661 & 3.005771 & $\mathbf{H}$ & -1.880718 & 0.147101 & 3.225568 \\
\hline C & -0.413086 & -1.510096 & 1.498965 & $\mathbf{H}$ & 0.459698 & 0.236450 & 4.073483 \\
\hline 0 & -0.483411 & -2.690324 & 1.285228 & $\mathbf{H}$ & 1.003705 & 0.845918 & 2.487537 \\
\hline$C$ & 0.318653 & -1.107283 & 2.562045 & $\mathbf{H}$ & 2.426598 & -3.907865 & 0.634276 \\
\hline C & 2.659791 & -2.850929 & 0.774867 & $\mathbf{H}$ & 2.205367 & -2.530564 & 1.709664 \\
\hline r & -3.806509 & -0.341520 & -1.508027 & $\mathbf{H}$ & 3.744508 & -2.758711 & 0.868835 \\
\hline r & -2.356278 & 0.589429 & -3.007312 & \multicolumn{4}{|c|}{ phenanthrene-9,10-dione } \\
\hline r & -1.672378 & 1.676277 & -1.817930 & \multicolumn{3}{|c|}{24} & \\
\hline$r$ & 1.206600 & -0.477197 & -2.903007 & \multicolumn{4}{|c|}{ scf done: -689.040693} \\
\hline$H$ & -0.124567 & 0.052240 & -3.932212 & C & -1.009319 & 0.187739 & 2.801308 \\
\hline 1 & 0.6 & 1.185806 & -2 & $c$ & 32 & 74 & 4.176989 \\
\hline $\boldsymbol{H}$ & -1.604056 & 82496 & -3.1 & C & 74 & 106 & 588 \\
\hline H & -0.277862 & -2.354943 & -2.119731 & C & 1.539552 & -0.265464 & 3.797433 \\
\hline$r$ & 340 & 3 & -0 & C & 82 & 52 & 379 \\
\hline H & -3.112490 & -2.386253 & -1.456652 & C & 0.038705 & -0.075751 & 1.931658 \\
\hline r & 2.874510 & 3.254879 & 0.279837 & $\pi$ & -0.166910 & -0.088656 & 0.871717 \\
\hline 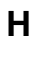 & 4.762339 & 1.685290 & 0.441211 & $\mathbf{H}$ & -1.998898 & 0.368719 & 2.400815 \\
\hline H & 4.377553 & -0.725023 & 0.121644 & $\mathbf{H}$ & -1.615442 & 0.428277 & 4.853674 \\
\hline r & 7 & 5 & 8 & $\mathbf{H}$ & 61 & 50 & 185 \\
\hline H & -0.646194 & 4.318480 & 1.022654 & C & 2.456960 & -0.604701 & 1.483097 \\
\hline$r$ & 0.183756 & 3.080803 & 1.968403 & C & 2.260827 & -0.743158 & 0.104078 \\
\hline H & 1.111488 & 4.330390 & 1.145447 & H & 1.271241 & -0.651258 & -0.318052 \\
\hline H & -0.340097 & 4.413736 & -1.488573 & C & 3.319035 & -1.007321 & -0.752944 \\
\hline
\end{tabular}




\begin{tabular}{|c|c|c|c|c|c|c|c|}
\hline $\mathbf{H}$ & 3.129895 & -1.110396 & -1.814084 & $\mathbf{H}$ & 1.524179 & -0.790102 & -2.462249 \\
\hline C & 4.613971 & -1.141813 & -0.258896 & $\mathbf{H}$ & -0.739545 & -0.473456 & -3.414583 \\
\hline $\mathbf{H}$ & 5.438093 & -1.347853 & -0.929243 & $\mathbf{H}$ & -2.652230 & 0.001630 & -1.906371 \\
\hline C & 4.831832 & -1.013422 & 1.101200 & \multicolumn{4}{|c|}{ CAAC } \\
\hline $\mathbf{H}$ & 5.822307 & -1.113821 & 1.524477 & \multicolumn{3}{|c|}{71} & \\
\hline C & 3.770963 & -0.752450 & 1.971978 & \multicolumn{4}{|c|}{ scf done: -1110.008886} \\
\hline C & 4.072697 & -0.638414 & 3.416352 & C & 2.534431 & -1.112950 & -0.412066 \\
\hline C & 2.878444 & -0.487934 & 4.387466 & C & 1.847957 & 0.061882 & -0.071269 \\
\hline 0 & 3.075146 & -0.544079 & 5.580635 & C & 2.432808 & 1.328235 & -0.249248 \\
\hline 0 & 5.197754 & -0.669628 & 3.862188 & C & 3.762876 & 1.386792 & -0.661566 \\
\hline \multicolumn{4}{|c|}{ phenanthro[9,10-d][1,3]dioxol-2-one } & C & 4.486125 & 0.231194 & -0.916681 \\
\hline \multicolumn{4}{|c|}{26} & C & 3.865662 & -1.003107 & -0.816721 \\
\hline \multicolumn{4}{|c|}{ scf done: -802.438286} & $\mathbf{N}$ & 0.501588 & -0.012218 & 0.452218 \\
\hline C & -1.022556 & 0.134448 & 2.809695 & C & -0.545159 & 0.111101 & -0.317553 \\
\hline C & -0.789353 & 0.214929 & 4.165831 & C & -1.755554 & 0.166535 & 0.594415 \\
\hline C & 0.501748 & 0.031981 & 4.681910 & C & -1.248151 & -0.167611 & 2.027240 \\
\hline C & 1.548574 & -0.231444 & 3.829318 & C & 0.286557 & -0.131038 & 1.968543 \\
\hline C & 1.323160 & -0.312672 & 2.443585 & C & -2.914653 & -0.761459 & 0.136321 \\
\hline C & 0.015299 & -0.136116 & 1.896491 & C & -3.530717 & -0.283211 & -1.185869 \\
\hline C & 2.343104 & -0.594163 & 1.508287 & C & -4.005383 & 1.165997 & -1.127699 \\
\hline C & 2.143144 & -0.649849 & 0.177808 & C & -2.858846 & 2.102703 & -0.747624 \\
\hline C & 0.878962 & -0.495825 & -0.432476 & C & -2.255048 & 1.637778 & 0.575626 \\
\hline C & -0.205093 & -0.216128 & 0.454975 & C & 0.923300 & -1.407142 & 2.510741 \\
\hline 0 & 3.349686 & -0.922404 & -0.442386 & C & 0.879450 & 1.070630 & 2.705721 \\
\hline C & 4.301592 & -1.015110 & 0.550210 & C & -3.309338 & 3.558772 & -0.661639 \\
\hline 0 & 3.685633 & -0.808492 & 1.765890 & C & -2.543254 & -2.266741 & 0.094570 \\
\hline C & -1.475377 & -0.046606 & -0.129770 & C & -3.765731 & -3.141565 & 0.388489 \\
\hline C & -1.661563 & -0.136283 & -1.492587 & C & 1.624855 & 2.609605 & -0.138731 \\
\hline C & -0.581827 & -0.405642 & -2.346026 & C & 1.152704 & 3.036314 & -1.537842 \\
\hline C & 0.677571 & -0.581894 & -1.821611 & C & 1.846636 & -2.463756 & -0.502275 \\
\hline 0 & 5.453385 & -1.235024 & 0.386237 & C & 1.636277 & -2.821961 & -1.982494 \\
\hline $\mathbf{H}$ & -2.030245 & 0.281713 & 2.449527 & C & -1.872923 & -2.702188 & -1.211680 \\
\hline $\mathbf{H}$ & -2.331195 & 0.161629 & 0.495578 & C & 2.598734 & -3.583745 & 0.224444 \\
\hline $\mathbf{H}$ & -1.612181 & 0.422765 & 4.837707 & C & 2.364556 & 3.744813 & 0.573815 \\
\hline $\mathbf{H}$ & 0.673187 & 0.097035 & 5.748523 & H & -1.625449 & 0.549989 & 2.755964 \\
\hline $\mathbf{H}$ & 2.552136 & -0.376281 & 4.206672 & $\mathbf{H}$ & -1.587794 & -1.151270 & 2.346472 \\
\hline
\end{tabular}




\begin{tabular}{|c|c|c|c|c|c|c|c|}
\hline $\mathbf{H}$ & -3.015395 & 1.733077 & 1.360469 & $\mathbf{H}$ & 1.696194 & 4.597908 & 0.708963 \\
\hline H & -1.433853 & 2.300616 & 0.862506 & $\mathbf{H}$ & 3.223786 & 4.096091 & -0.000601 \\
\hline H & -2.086450 & 2.018038 & -1.517123 & $\mathbf{H}$ & 2.003926 & 3.266886 & -2.182688 \\
\hline $\mathbf{H}$ & -4.811213 & 1.268160 & -0.389325 & $\mathbf{H}$ & 0.522876 & 3.927195 & -1.472290 \\
\hline H & -4.426292 & 1.460951 & -2.093528 & $\mathbf{H}$ & 0.573923 & 2.235539 & -1.998852 \\
\hline H & -2.784920 & -0.371608 & -1.976961 & A1 & & & \\
\hline H & -4.364395 & -0.937229 & -1.455140 & $7:$ & & & \\
\hline H & -3.684949 & -0.650365 & 0.911394 & scf & done: -1223 & .399260 & \\
\hline H & 4.234448 & 2.350484 & -0.800248 & C & -0.510066 & 0.109419 & -0.189651 \\
\hline $\mathrm{H}$ & 5.521880 & 0.295748 & -1.226619 & C & -0.469602 & 0.233143 & -1.492702 \\
\hline $\mathrm{H}$ & 4.415226 & -1.898037 & -1.078217 & 0 & -0.439040 & 0.308131 & -2.669852 \\
\hline H & 0.507416 & -2.294425 & 2.036119 & $\mathbf{N}$ & 0.642320 & -0.042684 & 0.616516 \\
\hline H & 0.729099 & -1.476284 & 3.582723 & C & 0.329401 & -0.048731 & 2.062147 \\
\hline H & 2.003708 & -1.405439 & 2.364714 & C & -1.194248 & -0.290435 & 2.054231 \\
\hline H & 1.947582 & 1.168390 & 2.509406 & $\mathbf{H}$ & -1.684430 & 0.262188 & 2.855343 \\
\hline H & 0.746881 & 0.930306 & 3.779956 & $\mathbf{H}$ & -1.386721 & -1.346891 & 2.228201 \\
\hline H & 0.387006 & 2.000908 & 2.428927 & C & -1.769013 & 0.133823 & 0.673864 \\
\hline H & -3.735464 & 3.896051 & -1.609456 & C & -2.342802 & 1.564914 & 0.778390 \\
\hline $\mathbf{H}$ & -2.473115 & 4.218904 & -0.417207 & $\mathbf{H}$ & -3.061920 & 1.580711 & 1.606513 \\
\hline H & -4.073156 & 3.687341 & 0.111436 & $\mathbf{H}$ & -1.540252 & 2.254129 & 1.048040 \\
\hline H & -1.824072 & -2.452276 & 0.897282 & C & -3.050922 & 2.059634 & -0.479875 \\
\hline H & -1.446837 & 02333 & 3753 & $\mathbf{H}$ & -2.326690 & 2.063040 & -1.302416 \\
\hline $\mathbf{H}$ & -1.076881 & -2.015130 & -1.496806 & C & -4.174080 & 1.086825 & -0.838668 \\
\hline H & -2.591110 & -2.739128 & -2.033252 & $\mathbf{H}$ & -4.927510 & 1.106335 & -0.041414 \\
\hline H & -4.550660 & -2.985051 & -0.35 & $\mathbf{H}$ & -4.676828 & 19 & -1.753645 \\
\hline H & -4.188097 & -2.917988 & 1.371102 & C & -3.643624 & -0.333647 & -1.014819 \\
\hline H & -3.502226 & -4.2 & 1 & $\mathbf{H}$ & -2.995656 & 3 & -1.893049 \\
\hline H & 0.860375 & -2.371200 & -0.054815 & $\mathbf{H}$ & -4.470872 & -1.014427 & -1.231681 \\
\hline$\Pi$ & 3.566652 & -3.783184 & -0.239444 & $C$ & -2.884498 & -0.846787 & 0.216037 \\
\hline H & 8 & 27 & 0 & $\mathbf{H}$ & 182 & 190 & 209 \\
\hline $\mathbf{H}$ & 2.775494 & -3.338792 & 1.272079 & C & 1.947689 & 0.057984 & 0.055308 \\
\hline$n$ & 1.081139 & -2.035946 & -2.494679 & C & 2.524411 & 1.316207 & -0.220120 \\
\hline H & 1.076700 & -3.755048 & -2.075055 & C & 3.827044 & 1.359493 & -0.716009 \\
\hline H & 2.594486 & -2.947589 & -2.491278 & H & 4.286961 & 2.318407 & -0.919015 \\
\hline H & 0.729317 & 2.393528 & 0.43 & C & 4.537742 & 0.196643 & -0.96 \\
\hline H & 2.722470 & 3.434470 & 1.557096 & $\mathbf{H}$ & 5.551727 & 0.251437 & -1.346807 \\
\hline
\end{tabular}




\begin{tabular}{|c|c|c|c|c|c|c|c|}
\hline C & 3.932445 & -1.035494 & -0.778328 & $\mathbf{H}$ & 0.793288 & 2.373974 & 0.378471 \\
\hline H & 4.471915 & -1.939399 & -1.031890 & C & 2.462191 & 3.645384 & 0.800295 \\
\hline C & 2.630249 & -1.127120 & -0.289139 & $\mathbf{H}$ & 2.707839 & 3.239276 & 1.781534 \\
\hline & 1.066138 & -1.185860 & 2.776384 & $\mathbf{H}$ & 1.827921 & 4.523046 & 0.944623 \\
\hline & 0.789520 & -2.154849 & 2.365054 & $\mathbf{H}$ & 3.391480 & 3.985668 & 0.338986 \\
\hline & 0.818425 & -1.181056 & 3.839550 & C & 1.446041 & 3.212759 & -1.464677 \\
\hline & 2.146499 & -1.065585 & 2.682649 & $\mathbf{H}$ & 2.367048 & 3.505364 & -1.973942 \\
\hline & 0.694056 & 1.264467 & 2.771804 & $\mathbf{H}$ & 0.822692 & 4.104339 & -1.361375 \\
\hline & 1.764200 & 1.455087 & 2.693084 & $\mathbf{H}$ & 0.921587 & 2.502804 & -2.103186 \\
\hline & 0.443752 & 1.193227 & 3.832403 & A2 & & & \\
\hline & 0.160689 & 2.117427 & 2.357942 & 9 & & & \\
\hline C & -3.562244 & 3.487050 & -0.299347 & scf & done: -1912 & .4733202 & \\
\hline I & -4.057811 & 3.845181 & -1.204461 & C & 3.928985 & 0.888996 & 0.270371 \\
\hline & -2.744518 & 4.174437 & -0.069814 & C & 3.698984 & -0.621852 & 0.170283 \\
\hline & -4.284599 & 3.541089 & 0.520373 & C & 4.352858 & -1.220247 & -1.073398 \\
\hline & -2.412676 & -2.324501 & 0.059677 & C & 2.614832 & 1.621442 & -0.127065 \\
\hline & -1.472410 & -2.432814 & 0.604758 & C & 1.637626 & 0.472870 & -0.221572 \\
\hline & -2.124734 & -2.775866 & -1.376516 & $\mathbf{N}$ & 2.184946 & -0.689898 & 0.008695 \\
\hline $\mathbf{H}$ & -1.709463 & -3.785968 & -1.363462 & C & 2.273907 & 2.680009 & 0.983050 \\
\hline & -1.404392 & -2.133156 & -1.877557 & C & 1.233726 & 3.709783 & 0.544900 \\
\hline & -3.032983 & -2.805139 & -1.981414 & C & 1.684164 & 4.449421 & -0.709528 \\
\hline & -3.427716 & -3.272098 & 0.707164 & C & 1.866475 & 3.481213 & -1.875155 \\
\hline & -4.407579 & -3.177839 & 0.230155 & C & 2.831298 & 2.355974 & -1.491284 \\
\hline & -3.554109 & -3.053706 & 1.770232 & C & 1.533402 & -1.991243 & -0.044162 \\
\hline & -3.113568 & -4.313987 & 0.611090 & C & 1.341318 & -2.614073 & -1.290449 \\
\hline & 1.946159 & -2.480965 & -0.243623 & C & 0.895261 & -3.936123 & -1.283599 \\
\hline & 0.979345 & -2.333380 & 0.232900 & C & 0.620981 & -4.600679 & -0.101079 \\
\hline & 2.729946 & -3.523631 & 0.560617 & C & 0.728891 & -3.930108 & 1.105639 \\
\hline & 3.687316 & -3.754595 & 0.088641 & C & 1.168007 & -2.608851 & 1.165675 \\
\hline & 2.164104 & -4.455935 & 0.625675 & C & 1.472446 & -1.910203 & -2.632819 \\
\hline & 2.933631 & -3. & 59 & C & 0.080048 & -1.739810 & -3.267622 \\
\hline & 1.679249 & -2.982584 & -1.671657 & C & 1.115490 & -1.889961 & 2.504541 \\
\hline & 1.108574 & -2.252311 & -2.246056 & C & 1.864571 & -2.638774 & 3.616356 \\
\hline & 1.111851 & -3.915724 & -1.647884 & C & 4.175960 & -1.369437 & 1.405 \\
\hline & 2.614878 & -3.169642 & -2.203541 & C & 0.229471 & 0.567877 & -0.733545 \\
\hline & 1.747853 & 2.613695 & -0.081136 & 0 & 0.012094 & 1.123659 & -1.779298 \\
\hline
\end{tabular}




\begin{tabular}{|c|c|c|c|c|c|c|c|}
\hline C & 2.379356 & 4.184437 & -3.131302 & $\mathbf{H}$ & 3.934923 & -2.429716 & 1.350392 \\
\hline C & 1.999002 & 2.084341 & 2.389185 & $\mathbf{H}$ & 3.752934 & -0.954014 & 2.316783 \\
\hline C & 2.592534 & 2.997506 & 3.467889 & $\mathbf{H}$ & 4.055194 & -0.691008 & -1.976788 \\
\hline C & -0.608892 & -0.105113 & 0.040207 & $\mathbf{H}$ & 5.434752 & -1.132670 & -0.968288 \\
\hline C & -1.999178 & 0.110600 & -0.067873 & $\mathbf{H}$ & 4.106568 & -2.274842 & -1.180816 \\
\hline C & -2.438799 & 1.442118 & 0.002172 & $\mathbf{H}$ & 3.358394 & 4.642754 & -2.958356 \\
\hline$C$ & -3.905368 & 1.601219 & 0.000420 & $\mathbf{H}$ & 1.690864 & 4.974898 & -3.436443 \\
\hline C & -4.779662 & 0.487319 & -0.024597 & $\mathbf{H}$ & 2.476695 & 3.487606 & -3.967735 \\
\hline$C$ & -4.237973 & -0.865054 & -0.060624 & $\mathbf{H}$ & 2.528574 & 1.128517 & 2.466238 \\
\hline C & -2.820862 & -1.035568 & -0.085488 & $\mathbf{H}$ & 0.054877 & 1.159069 & 1.954655 \\
\hline C & -5.041746 & -2.014903 & -0.080320 & $\mathbf{H}$ & -0.059152 & 2.730810 & 2.699111 \\
\hline$C$ & -4.502553 & -3.287680 & -0.121565 & $\mathbf{H}$ & 0.427567 & 1.337379 & 3.666576 \\
\hline C & -3.111576 & -3.446891 & -0.155885 & $\mathbf{H}$ & 3.671501 & 3.118113 & 3.342350 \\
\hline C & -2.288547 & -2.344143 & -0.143480 & $\mathbf{H}$ & 2.138789 & 3.990521 & 3.430883 \\
\hline C & -4.423916 & 2.903476 & 0.038492 & $\mathbf{H}$ & 2.410976 & 2.590843 & 4.464883 \\
\hline C & -5.784533 & 3.125757 & 0.047664 & $\mathbf{H}$ & 1.878660 & -0.912823 & -2.472697 \\
\hline$c$ & -6.659835 & 2.033123 & 0.021033 & $\mathbf{H}$ & 3.395212 & -2.809719 & -3.194868 \\
\hline C & -6.165485 & 0.745661 & -0.014148 & $\mathbf{H}$ & 1.991007 & -3.616624 & -3.887517 \\
\hline C & -1.656192 & 2.423771 & 0.085244 & $\mathbf{H}$ & 2.507555 & -2.062267 & -4.526554 \\
\hline C & 0.523098 & 1.809949 & 2.686721 & $\mathbf{H}$ & -0.341355 & -2.710906 & -3.533420 \\
\hline$C$ & -0.346674 & -1.669121 & 2.929770 & $\mathbf{H}$ & 0.157587 & -1.140563 & -4.176178 \\
\hline c & 2.401332 & -2.644653 & -3.609447 & $\mathbf{H}$ & -0.619067 & -1.242861 & -2.599958 \\
\hline r & 4.745873 & 1.190410 & -0.381254 & $\mathbf{H}$ & 1.568846 & -0.907468 & 2.386980 \\
\hline H & 4.210693 & 2 & 1 & $\mathbf{H}$ & 9 & 57 & 577 \\
\hline$\vdash$ & 2.882016 & 1.616264 & -2.295088 & $\mathbf{H}$ & -0.8 & -2.623278 & 3.057162 \\
\hline 1 & 3.830776 & 2.796654 & -1.413021 & $\mathbf{H}$ & -0.377115 & -1.138004 & 3.882784 \\
\hline r & 0.894862 & 3.047826 & -2.098 & $\mathbf{H}$ & 1 & -2.026 & 379 \\
\hline r & 0.944175 & 5.206052 & -0.980900 & $\mathbf{H}$ & 2.888175 & -2.887489 & 3.339260 \\
\hline H & 2.626917 & 4.980 & -0.517112 & $\mathbf{H}$ & 1.00 & -3.568781 & 013 \\
\hline H & 0.263876 & 3.241242 & 0.370046 & $\mathbf{H}$ & -3.713463 & 3.719032 & 0.059561 \\
\hline$r$ & 1.092022 & 4.421847 & 1.362057 & $\mathbf{H}$ & -6.175005 & 4.135684 & 0.074978 \\
\hline r & 3.227060 & 3.218905 & 1.060727 & $\mathbf{H}$ & -6.117794 & -1.911980 & -0.059881 \\
\hline 1 & 0.438278 & -4.428622 & 2.019999 & $\mathbf{H}$ & -5.153962 & -4.152174 & -0.134369 \\
\hline H & 0.278884 & -5.627500 & -0.122711 & $\mathbf{H}$ & -7.730953 & 2.195653 & 0.026924 \\
\hline & 0.738529 & .441012 & -2.226764 & $\mathbf{H}$ & -6.866391 & -0.076986 & -0.035687 \\
\hline & 5.260904 & -1.271694 & 1.462085 & H & -2.677112 & -4.438836 & -0.198437 \\
\hline
\end{tabular}




\begin{tabular}{|c|c|c|c|c|c|c|c|}
\hline $\mathbf{H}$ & -1.219430 & -2.469022 & -0.181600 & $\mathbf{H}$ & 2.181323 & 0.829434 & -2.944389 \\
\hline \multicolumn{4}{|l|}{ A3 } & $\mathbf{H}$ & 1.214431 & 2.083454 & 0.695418 \\
\hline \multicolumn{4}{|c|}{97} & $\mathbf{H}$ & -1.028865 & 2.462417 & 0.658186 \\
\hline \multicolumn{4}{|c|}{ scf done: -1912.494983} & $\mathbf{H}$ & -0.382747 & 4.066137 & 0.720418 \\
\hline C & 2.332197 & 1.269729 & -1.960600 & $\mathbf{H}$ & -0.943672 & 4.407911 & -1.671800 \\
\hline C & 3.058221 & 0.241718 & -1.077673 & $\mathbf{H}$ & -2.339241 & 3.812550 & -0.793009 \\
\hline $\mathbf{N}$ & 1.928606 & -0.408747 & -0.356927 & $\mathbf{H}$ & -1.890940 & 1.529924 & -1.589867 \\
\hline C & 0.637521 & 0.106280 & -0.739031 & $\mathbf{H}$ & 0.465392 & 2.840492 & -2.989804 \\
\hline C & 0.945726 & 1.552511 & -1.358246 & $\mathbf{H}$ & -0.016593 & 1.199230 & -3.271004 \\
\hline C & 0.936731 & 2.625144 & -0.206658 & $\mathbf{H}$ & 2.693909 & -4.877798 & 0.607602 \\
\hline C & -0.475964 & 3.191216 & 0.074829 & $\mathbf{H}$ & 3.247502 & -4.392557 & 2.956784 \\
\hline C & -1.337384 & 3.539498 & -1.137411 & $\mathbf{H}$ & 3.042771 & -2.087929 & 3.792607 \\
\hline C & -1.414439 & 2.367965 & -2.108647 & $\mathbf{H}$ & 4.319046 & -1.508903 & -1.363213 \\
\hline C & 0.005342 & 1.973995 & -2.506588 & $\mathbf{H}$ & 4.650048 & -0.175087 & -2.466875 \\
\hline C & 2.168438 & -1.511150 & 0.548395 & $\mathbf{H}$ & 3.221988 & -1.181058 & -2.719585 \\
\hline C & 2.257999 & -2.849388 & 0.085530 & $\mathbf{H}$ & 3.570270 & 1.588288 & 0.568261 \\
\hline C & 2.634239 & -3.860603 & 0.970647 & $\mathbf{H}$ & 4.532615 & 0.112277 & 0.497806 \\
\hline C & 2.940046 & -3.595263 & 2.291102 & $\mathbf{H}$ & 4.829361 & 1.407908 & -0.657843 \\
\hline C & 2.829241 & -2.298050 & 2.752908 & $\mathbf{H}$ & -2.324109 & 1.832117 & -4.010136 \\
\hline C & 2.432613 & -1.252307 & 1.918960 & $\mathbf{H}$ & -3.271672 & 2.978859 & -3.056102 \\
\hline C & 3.853333 & -0.725505 & -1.961325 & $\mathbf{H}$ & -1.818540 & 3.521865 & -3.901602 \\
\hline C & 4.049905 & 0.882791 & -0.102547 & $\mathbf{H}$ & 2.955032 & 3.268569 & -0.559464 \\
\hline C & -2.256577 & 2.691751 & -3.339552 & $\mathbf{H}$ & 2.613323 & 5.525526 & -1.374578 \\
\hline C & 2.010777 & 3.745810 & -0.306271 & $\mathbf{H}$ & 1.655855 & 90 & -2.359860 \\
\hline C & 1.767956 & 4.833622 & -1.355499 & $\mathbf{H}$ & 0.874950 & 5.417904 & -1.129212 \\
\hline C & 1.912393 & -3.290435 & -1.324042 & $\mathbf{H}$ & 1.822145 & -2.410797 & -1.941644 \\
\hline C & 2.987041 & -4.177305 & -1.967107 & $\mathbf{H}$ & 2.738227 & -4.352202 & -3.016098 \\
\hline C & 2.246231 & 0.094941 & 2.595757 & $\mathbf{H}$ & 3.971098 & -3.709627 & -1.927111 \\
\hline C & 1.155834 & -0.015284 & 3.673070 & $\mathbf{H}$ & 3.059561 & -5.152906 & -1.482778 \\
\hline C & 2.237407 & 4.388133 & 1.068968 & $\mathbf{H}$ & 1.909265 & 0.798043 & 1.841087 \\
\hline C & 3.526808 & 0.640133 & 3.245770 & $\mathbf{H}$ & 0.901086 & 0.972048 & 4.065482 \\
\hline C & 0.555451 & -4.014220 & -1.335142 & $\mathbf{H}$ & 0.252927 & -0.476866 & 3.281227 \\
\hline C & -0.028391 & -0.755700 & -1.846634 & $\mathbf{H}$ & 1.501644 & -0.620253 & 4.513234 \\
\hline 0 & 0.545285 & -1.029224 & -2.863461 & $\mathbf{H}$ & 3.077599 & 5.084741 & 1.028927 \\
\hline 0 & -1.295463 & -1.207553 & -1.695685 & $\mathbf{H}$ & 2.465153 & 3.633091 & 1.825177 \\
\hline $\mathbf{H}$ & 2.922496 & 2.170635 & -2.102516 & $\mathbf{H}$ & 1.365870 & 4.950086 & 1.410217 \\
\hline
\end{tabular}




\begin{tabular}{|c|c|c|c|c|c|c|c|}
\hline $\mathbf{H}$ & 3.342275 & 1.637031 & 3.654097 & 0 & -0.525653 & -0.599183 & -0.664042 \\
\hline $\mathbf{H}$ & 4.354608 & 0.710661 & 2.544550 & C & 0.541257 & 0.644997 & 1.165093 \\
\hline $\mathbf{H}$ & 3.845809 & 0.003688 & 4.073467 & 0 & -0.672056 & 0.630925 & 1.777612 \\
\hline $\mathbf{H}$ & 0.239852 & -4.214847 & -2.360842 & C & -1.809189 & 0.144444 & 1.161643 \\
\hline $\mathbf{H}$ & -0.222743 & -3.421917 & -0.854453 & C & -1.710666 & -0.473728 & -0.034370 \\
\hline $\mathbf{H}$ & 0.620025 & -4.966065 & -0.802588 & C & 0.688534 & 1.491063 & -1.372490 \\
\hline 0 & -0.173799 & 0.163998 & 0.456642 & C & 0.927482 & 2.939469 & -0.812524 \\
\hline C & -2.049703 & -0.849513 & -0.594719 & C & -0.321814 & 3.524485 & -0.136426 \\
\hline C & -1.495390 & -0.163121 & 0.429777 & C & -1.497564 & 3.598602 & -1.106011 \\
\hline C & -2.312538 & 0.252382 & 1.536059 & C & -1.831499 & 2.223894 & -1.673511 \\
\hline C & -3.682189 & -0.128312 & 1.571667 & C & -0.577710 & 1.575646 & -2.267209 \\
\hline C & -4.244833 & -0.904689 & 0.481597 & C & -2.871879 & -1.022389 & -0.668743 \\
\hline C & -3.418396 & -1.248056 & -0.619184 & C & -4.137298 & -0.865198 & -0.044020 \\
\hline C & -4.452148 & 0.295365 & 2.672649 & C & -4.232486 & -0.157944 & 1.222341 \\
\hline C & -3.912822 & 1.066014 & 3.678963 & C & -3.050089 & 0.346348 & 1.829453 \\
\hline C & -2.569299 & 1.456987 & 3.620852 & C & -5.259054 & -1.407176 & -0.701774 \\
\hline C & -1.786192 & 1.056019 & 2.563821 & C & -5.140970 & -2.064704 & -1.907043 \\
\hline C & -3.945776 & -1.977764 & -1.703232 & C & -3.885907 & -2.210842 & -2.513449 \\
\hline C & -5.265007 & -2.369230 & -1.700458 & C & -2.767439 & -1.694490 & -1.900421 \\
\hline C & -6.090491 & -2.043302 & -0.615554 & C & -3.120088 & 1.033136 & 3.057541 \\
\hline C & -5.587797 & -1.326839 & 0.448786 & C & -4.333316 & 1.225244 & 3.678210 \\
\hline $\mathbf{H}$ & -5.495142 & 0.020611 & 2.732061 & C & -5.507347 & 0.735237 & 3.089769 \\
\hline H & -4.533171 & 1.376569 & 4.510069 & C & -5.452792 & 0.059602 & 1.889595 \\
\hline H & -2.146808 & 2.074564 & 4.403117 & 0 & 1.484019 & 0.975221 & 1.818267 \\
\hline $\mathbf{H}$ & -0.754319 & 1.356591 & 2.507052 & C & 2.358232 & -1.480119 & 0.343954 \\
\hline $\mathbf{H}$ & -3.296916 & -2.226933 & -2.530391 & C & 3.523987 & -1.163315 & 1.092969 \\
\hline H & -5.663845 & -2.931068 & 535420 & C & 19 & 399 & 2682 \\
\hline H & -7.127238 & -2.354756 & -0.612006 & C & 3.370015 & -3.290938 & 2.247002 \\
\hline H & -6.246014 & -1.089497 & 1.271935 & C & 2.269186 & -3.619611 & 992 \\
\hline A4 & & & & C & 1.754506 & -2.747990 & 0.518279 \\
\hline yl & & & & C & 3.673376 & -0.703803 & -2.248505 \\
\hline \multicolumn{4}{|c|}{ scf done: -1912.493607} & C & 1.386943 & -1.324303 & -2.936114 \\
\hline C & 1.885950 & 1.075915 & -2.265912 & C & -2.947311 & 2.276219 & -2.714533 \\
\hline C & 2.199431 & -0.398872 & -2.010281 & C & 2.269143 & 3.189317 & -0.044829 \\
\hline $\mathbf{N}$ & 1.828268 & -0.486901 & -0.569769 & C & 3.235022 & 4.018469 & -0.902152 \\
\hline C & 0.645979 & 0.261556 & -0.322002 & C & 4.352170 & 0.099961 & 0.914040 \\
\hline
\end{tabular}




\begin{tabular}{lllllllll} 
C & 5.762492 & -0.240405 & 0.395474 & H & 1.874283 & -4.328007 & -1.719289 \\
C & 0.587368 & -3.279467 & -0.297201 & H & 1.230998 & -5.366005 & -0.451400 \\
C & -0.631962 & -3.587409 & 0.583134 & H & 0.177709 & -4.828521 & -1.760562 \\
C & 2.132038 & 3.878792 & 1.318776 & H & -0.435262 & -4.420550 & 1.260996 \\
C & 0.994794 & -4.522240 & -1.102674 & H & -1.490083 & -3.855769 & -0.036358 \\
C & 4.495321 & 0.923057 & 2.203396 & H & -0.912442 & -2.726595 & 1.189499 \\
H & 1.676889 & 1.271904 & -3.317152 & H & 3.848313 & 0.717949 & 0.177272 \\
H & 2.765646 & 1.650232 & -1.993590 & H & 3.529804 & 1.173998 & 2.628228 \\
H & -0.823816 & 0.594508 & -2.666311 & H & 5.074600 & 0.378724 & 2.952380 \\
H & -0.283004 & 2.186517 & -3.126789 & H & 5.033468 & 1.849958 & 1.988586 \\
H & -2.192230 & 1.620135 & -0.844004 & H & 6.290674 & 0.673321 & 0.111658 \\
H & -2.375498 & 4.018662 & -0.607083 & H & 5.742810 & -0.906983 & -0.464608 \\
H & -1.243876 & 4.280718 & -1.927144 & H & 6.349742 & -0.729830 & 1.174924 \\
\hline H & -0.608060 & 2.947244 & 0.745708 & H & -1.792920 & -1.803113 & -2.352955 \\
H & -0.092816 & 4.526940 & 0.225134 & H & -3.796712 & -2.728396 & -3.460028 \\
H & 1.021207 & 3.514010 & -1.741724 & H & -6.373270 & -0.305487 & 1.457245 \\
H & 4.875583 & -1.825017 & 2.611099 & H & -6.461384 & 0.887087 & 3.578171 \\
H & 3.747269 & -3.980001 & 2.992785 & H & -6.023203 & -2.469994 & -2.385998 \\
H & 1.793655 & -4.581123 & 1.624200 & H & -6.238891 & -1.312081 & -0.256676 \\
H & 3.875769 & -0.668749 & -3.319990 & H & -4.380147 & 1.754286 & 4.621546 \\
H & 3.931635 & -1.701379 & -1.891216 & H & -2.206501 & 1.402840 & 3.501037 \\
H & 4.318248 & 0.020022 & -1.761676 & A5 & & & \\
\hline & 0.31699 & -1.195668 & -2.808327 & & 97 & & \\
\hline
\end{tabular}

$\begin{array}{llll}\text { H } & 0.316995 & -1.195668 & -2.808327\end{array}$

H $\quad \begin{array}{llll}1.637257 & -1.098110 & -3.974567\end{array}$

H $\quad \begin{array}{lll}1.634078 & -2.369043 & -2.756023\end{array}$

$\begin{array}{llll}\text { H } & -2.643168 & 2.863985 & -3.585935\end{array}$

H $\quad \begin{array}{llll}\text { H.847158 } & 2.735001 & -2.298795\end{array}$

$\begin{array}{lllll}H & -3.211653 & 1.273585 & -3.057587\end{array}$

H $\quad 2.728854 \quad 2.224080 \quad 0.145116$

H $\quad 1.430647 \quad 3.373136 \quad 1.977212$

H $\quad 1.820130 \quad 4.920523 \quad 1.211872$

H $\quad 3.102353 \quad 3.879859 \quad 1.818922$

H $\quad 3.434145 \quad 3.559878 \quad-1.872086$

H $2.819402 \quad 5.012916-1.090811$

H $\quad 4.192020 \quad 4.151959 \quad-0.391963$

H $\quad 0.289962 \quad-2.515619 \quad-0.998137$

\begin{tabular}{|c|c|c|c|}
\hline & 0005 & 10510 & 725 \\
\hline & 3.484665 & 0.022254 & 0.770866 \\
\hline & 3.362702 & 1.543615 & 0.846733 \\
\hline & 2.054459 & 1.979265 & .128100 \\
\hline & 1.384242 & 0.634466 & -0.15820 \\
\hline & 0.234399 & 0.438813 & -1.153075 \\
\hline & -0.884529 & 1.405835 & -0.843841 \\
\hline & -2.024417 & 0.681848 & -0.688899 \\
\hline & -1.765758 & -0.646193 & -0.716089 \\
\hline 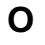 & -0.444354 & -0.889032 & -0.884757 \\
\hline & 1.312444 & 2.981273 & 1.091029 \\
\hline & 0.269047 & 3.886730 & 0.432243 \\
\hline
\end{tabular}




\begin{tabular}{|c|c|c|c|c|c|c|c|}
\hline C & 0.808687 & 4.591721 & -0.808221 & $\mathbf{H}$ & 2.819463 & 2.017268 & -1.906332 \\
\hline C & 1.338624 & 3.585499 & -1.827641 & $\mathbf{H}$ & 3.251733 & 3.405180 & -0.910116 \\
\hline c & 2.429856 & 2.733326 & -1.182907 & $\mathbf{H}$ & 0.522191 & 2.933299 & -2.132510 \\
\hline C & -3.324234 & 1.201048 & -0.488238 & H & 0.019731 & 5.199213 & -1.260542 \\
\hline C & -4.381363 & 0.256431 & -0.298263 & $\mathbf{H}$ & 1.614757 & 5.283002 & -0.527713 \\
\hline C & -4.099284 & -1.171366 & -0.326336 & $\mathbf{H}$ & -0.604794 & 3.306802 & 0.157667 \\
\hline 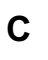 & -2.766668 & -1.630343 & -0.554069 & $\mathbf{H}$ & -0.050143 & 4.627513 & 1.170525 \\
\hline C & -5.673533 & 0.774703 & -0.082990 & $\mathbf{H}$ & 2.140801 & 3.648608 & 1.359798 \\
\hline c & -5.916571 & 2.131433 & -0.053843 & $\mathbf{H}$ & 0.564522 & -4.218688 & 2.249331 \\
\hline C & -4.868114 & 3.044811 & -0.244666 & $\mathbf{H}$ & 1.253929 & -5.623610 & 0.347908 \\
\hline C & -3.590032 & 2.584854 & -0.459563 & $\mathbf{H}$ & 2.162125 & -4.569611 & -1.680193 \\
\hline C & -2.469743 & -3.007817 & -0.567305 & $\mathbf{H}$ & 4.787723 & -0.275561 & 2.430989 \\
\hline C & -3.468822 & -3.931679 & -0.370884 & H & 3.787740 & -1.687022 & 2.080586 \\
\hline C & -4.787799 & -3.500293 & -0.155381 & $\mathbf{H}$ & 3.086500 & -0.273154 & 2.886799 \\
\hline C & -5.089981 & -2.155223 & -0.135455 & $\mathbf{H}$ & 4.362989 & 0.007690 & -1.221150 \\
\hline 0 & 0.758237 & 0.561474 & -2.280388 & $\mathbf{H}$ & 5.516799 & -0.046538 & 0.115987 \\
\hline c & 1.780856 & -1.803320 & 0.218122 & $\mathbf{H}$ & 4.601503 & -1.492354 & -0.307432 \\
\hline C & 1.195897 & -2.378044 & 1.361886 & $\mathbf{H}$ & 2.734866 & 4.921981 & -2.830982 \\
\hline C & 1.018697 & -3.759569 & 1.381737 & H & 1.121503 & 4.889229 & -3.549629 \\
\hline C & 1.393747 & -4.550440 & 0.309499 & H & 2.226136 & 3.537294 & -3.809900 \\
\hline C & 1.916497 & -3.955908 & -0.824334 & H & 1.471256 & 1.513679 & 2.659669 \\
\hline C & 2.108233 & -2.575729 & -0.910929 & H & -0 & 58 & 2913 \\
\hline 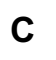 & 3.791451 & -0.599132 & 2.126372 & $\mathbf{H}$ & -1.332458 & 2.635486 & 2.231227 \\
\hline C & 4.548998 & $-0.4 C$ & -0.233197 & H & 86 & 49 & 33762 \\
\hline C & 1.888372 & 4.272194 & -3.076083 & H & 176 & 305 & 3.685279 \\
\hline$c$ & 0.820813 & 2.361500 & 2.424366 & $\mathbf{H}$ & 0.379906 & 4.258370 & 3.404115 \\
\hline C & 0.982619 & 3.3 & 77 & H & 92 & 38 & 694 \\
\hline C & 0.658598 & -1.583795 & 2.542225 & H & 2.644496 & -0.939253 & -2.176510 \\
\hline C & 1.207911 & -2.074387 & 3.890410 & $\pi$ & 4.673810 & -2.515956 & -2.065858 \\
\hline C & 2.536312 & -2.016702 & -2.260213 & H & 3.739774 & -3.683437 & -2.993274 \\
\hline C & 1.428177 & -2.260450 & -3.300371 & $\mathbf{H}$ & 4.143602 & -2.126613 & -3.703070 \\
\hline C & $-c$ & 50 & 8 & H & 15 & 65 & 319 \\
\hline C & 3.852337 & -2.620018 & -2.773575 & $\mathbf{H}$ & 1.686942 & -1.759286 & -4.234838 \\
\hline C & -0.876750 & -1.636563 & 2.000102 & 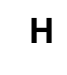 & 0.478840 & -1.861217 & -2.957956 \\
\hline r & 4.224588 & 2.01823 & 0.38 & $\mathbf{H}$ & 0.946988 & -0.542741 & 2.418931 \\
\hline H & 3.344629 & 1.858337 & 1.887344 & $\mathrm{H}$ & -1.308906 & -1.219449 & 1.662390 \\
\hline
\end{tabular}




$\begin{array}{cccc}\text { H } & -1.228326 & -2.665479 & 2.656831 \\ \text { H } & -1.259271 & -1.072996 & 3.419392 \\ \text { H } & 0.899827 & -1.393431 & 4.686745 \\ \text { H } & 2.294978 & -2.140541 & 3.898519 \\ \text { H } & 0.814595 & -3.061584 & 4.138479 \\ \text { H } & -2.771697 & 3.274282 & -0.618282 \\ \text { H } & -5.067101 & 4.109061 & -0.226449 \\ \text { H } & -6.115059 & -1.858350 & 0.035774 \\ \text { H } & -5.574978 & -4.228095 & -0.003624 \\ \text { H } & -6.923364 & 2.492654 & 0.113678 \\ \text { H } & -6.503444 & 0.098046 & 0.064004 \\ \text { H } & -3.241021 & -4.990304 & -0.382995 \\ \text { H } & -1.444749 & -3.315255 & -0.727871 \\ \text { MeCAAC } & & \end{array}$

52

scf done: $\mathbf{- 8 3 5 . 8 9 0 0 2 0}$
C $\quad-1.314239 \quad-0.163862 \quad 1.400214$
$\begin{array}{llll}\mathrm{N} & -0.601931 & -0.082690 & 0.040418\end{array}$
C $\quad-1.328635 \quad-0.123716 \quad-1.042761$
$\begin{array}{llll}C & -2.772775 & -0.262527 & -0.591319\end{array}$
$\begin{array}{llll}\text { C } & -2.720705 & -0.563691 & 0.932146\end{array}$
$\begin{array}{llll}\text { C } & 0.834320 & 0.061231 & -0.014907\end{array}$
$\begin{array}{llll}\text { C } & 1.627751 & -1.095916 & -0.060958\end{array}$
$\begin{array}{llll}\text { C } & 3.013285 & -0.942925 & -0.040277\end{array}$
$\begin{array}{llll}\text { C } & 3.593827 & 0.315956 & -0.003575\end{array}$
$\begin{array}{llll}\text { C } & 2.792329 & 1.446168 & -0.039823\end{array}$
$\begin{array}{llll}\text { C } & 1.401039 & 1.343772 & -0.063409\end{array}$
C $\quad 1.024740 \quad-2.473536 \quad-0.273906$
$\begin{array}{llll}\text { C } & 1.656216 & -3.559237 & 0.602029\end{array}$
$\begin{array}{llll}\text { C } & 0.561642 & 2.588762 & -0.289092\end{array}$
C $0.965865 \quad 3.769158 \quad 0.598773$
$\begin{array}{llll}\text { C } & -3.451854 & -1.392867 & -1.370535\end{array}$
$\begin{array}{llll}\text { C } & -3.482280 & 1.067716 & -0.898416\end{array}$
C $\quad-0.673657 \quad-1.202010 \quad 2.317765$
$\begin{array}{llll}\text { C } & -1.284722 & 1.194737 & 2.103113\end{array}$
$\begin{array}{llll}\text { C } & 0.605849 & 2.966040 & -1.778600\end{array}$

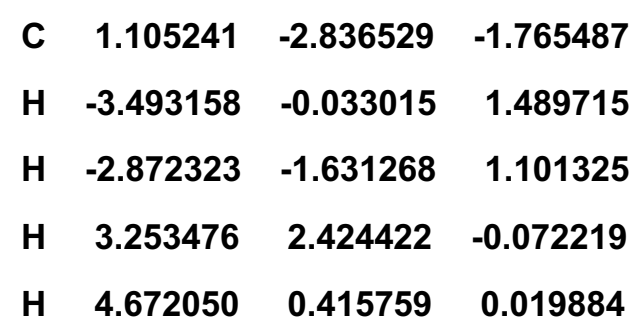

H $\quad 4.672050 \quad 0.415759 \quad 0.019884$

H $\quad 3.646161 \quad-1.819878 \quad-0.071771$

$\begin{array}{llll}H & -0.722591 & -2.202702 & 1.893524\end{array}$

$\begin{array}{llll}\text { H } & -1.210411 & -1.215974 & 3.268198\end{array}$

$\begin{array}{llll}\text { H } & 0.369727 & -0.961067 & 2.524558\end{array}$

H $\quad \begin{array}{llll}0.260666 & 1.518004 & 2.290883\end{array}$

$\begin{array}{llll}\text { H } & -1.790617 & 1.109939 & 3.066536\end{array}$

$\begin{array}{llll}H & -1.792428 & 1.964722 & 1.525137\end{array}$

$\begin{array}{llll}\text { H } & -0.032463 & -2.420930 & -0.026675\end{array}$

H $2.698596 \quad-3.741644 \quad 0.334103$

H $\quad 1.120046 \quad-4.502139 \quad 0.474612$

H $\quad 1.624950 \quad-3.289365 \quad 1.659093$

$\begin{array}{llll}\text { H } & 0.590732 & -2.085413 & -2.365855\end{array}$

H $\quad 0.637571 \quad-3.807354 \quad-1.947891$

$\begin{array}{llll}\text { H } & 2.144873 & -2.891755 & -2.096621\end{array}$

$\begin{array}{lllll}\text { H } & -0.471609 & 2.343974 & -0.063902\end{array}$

H $\quad 0.959575 \quad 3.497404 \quad 1.655903$

$\begin{array}{llll}H & 0.270398 & 4.599223 & 0.457431\end{array}$

H $\quad 1.963980 \quad 4.137932 \quad 0.354837$

H $\quad \begin{array}{lll}1.624007 & 3.213137 & -2.088210\end{array}$

$\begin{array}{lllll}H & -0.028808 & 3.834881 & -1.970451\end{array}$

$\begin{array}{lllll}H & 0.249694 & 2.135363 & -2.388589\end{array}$

$\begin{array}{llll}H & -3.417765 & 1.295736 & -1.962821\end{array}$

$\begin{array}{lllll}H & -4.536718 & 1.004305 & -0.617840\end{array}$

$\begin{array}{lllll}\text { H } & -3.036395 & 1.900360 & -0.351848\end{array}$

H $\quad-4.486451 \quad-1.519694 \quad-1.039407$

$\begin{array}{lllll}H & -3.450954 & -1.174695 & -2.439020\end{array}$

$\begin{array}{llll}\text { H } & -2.928383 & -2.339775 & -1.221392\end{array}$

A6

54

scf done: -949.282210

$\begin{array}{llll}\text { C } & 0.870836 & 1.757299 & -0.054433\end{array}$ 


\begin{tabular}{|c|c|c|c|c|c|c|c|}
\hline C & 0.883721 & 0.347035 & -0.109113 & H & -0.894151 & 2.244819 & 1.977808 \\
\hline C & 2.087025 & -0.359889 & 0.072078 & H & -1.781868 & 3.575993 & 1.222097 \\
\hline C & 3.273333 & 0.357299 & 0.232100 & $\mathbf{H}$ & -0.075096 & 3.771426 & 1.636295 \\
\hline C & 3.272997 & 1.742070 & 0.249039 & $\mathbf{H}$ & 1.094147 & -2.219161 & 0.022076 \\
\hline C & 2.076077 & 2.432594 & 0.121078 & $\mathbf{H}$ & 2.656645 & -2.154530 & -1.943456 \\
\hline $\mathbf{N}$ & -0.332674 & -0.367348 & -0.297645 & $\mathbf{H}$ & 2.913449 & -3.581459 & -0.929527 \\
\hline C & -1.257118 & -0.559037 & 0.749502 & $\mathbf{H}$ & 4.028295 & -2.216936 & -0.840351 \\
\hline C & -2.685287 & -0.709460 & 0.206966 & $\mathbf{H}$ & 3.615845 & -2.044089 & 1.734316 \\
\hline C & -2.433420 & -0.539100 & -1.317181 & $\mathbf{H}$ & 2.535236 & -3.433990 & 1.604538 \\
\hline C & -0.929442 & -0.785672 & -1.584974 & $\mathbf{H}$ & 1.957947 & -1.927437 & 2.327892 \\
\hline C & -3.614784 & 0.389371 & 0.739358 & C & -3.285873 & -2.081296 & 0.543636 \\
\hline C & -0.939552 & -0.714693 & 2.014273 & $\mathbf{H}$ & -3.392462 & -2.201288 & 1.623752 \\
\hline 0 & -0.702573 & -0.717734 & 3.166496 & $\mathbf{H}$ & -4.277522 & -2.181124 & 0.095150 \\
\hline C & -0.407143 & 0.064356 & -2.739093 & $\mathbf{H}$ & -2.660686 & -2.894874 & 0.178711 \\
\hline C & -0.661235 & -2.268600 & -1.892854 & $\mathbf{H}$ & -4.596544 & 0.323805 & 0.262817 \\
\hline C & 2.116799 & -1.873528 & 0.153096 & H & -3.759182 & 0.290116 & 1.817364 \\
\hline C & 2.584237 & -2.344558 & 1.538070 & $\mathbf{H}$ & -3.203619 & 1.379450 & 0.544555 \\
\hline C & -0.422772 & 2.544344 & -0.129358 & A7 & & & \\
\hline C & -0.817583 & 3.063137 & 1.261674 & $7 \varepsilon$ & & & \\
\hline C & -0.366580 & 3.691623 & -1.144733 & scf & done: -1638 & .344224 & \\
\hline C & 2.977332 & -2.491190 & -0.955920 & C & -2.210797 & -1.030646 & 1.813657 \\
\hline H & -3.067399 & -1.208365 & -1.899521 & C & 76203 & 597 & 2572 \\
\hline H & -2.677357 & 0.483596 & -1.608547 & C & -3.279585 & 1.153916 & 1.420981 \\
\hline H & 4.205931 & -0.177510 & 0.362340 & C & -3.535394 & 1.216474 & 2.794464 \\
\hline H & 4 & 2.2 & 12 & C & 69 & 51 & 8818 \\
\hline $\mathrm{H}$ & 2.080638 & 3.514522 & 0.160644 & C & -2.501237 & -0.905999 & 3.168760 \\
\hline H & -0.625502 & 4 & 4 & $\mathbf{N}$ & 38 & 8 & 176 \\
\hline H & -0.877138 & -0.254533 & -3.670874 & C & -1.391528 & -0.140205 & -1.153357 \\
\hline $\mathbf{H}$ & 0.672296 & -0.048787 & -2.848563 & C & -1.491934 & -0.710699 & -2.549495 \\
\hline $\mathbf{H}$ & 0.387435 & -2.429300 & -2.139341 & C & -3.022540 & -0.881238 & -2.694596 \\
\hline H & -1.261321 & -2.595445 & -2.745176 & C & -3.609713 & -0.951714 & -1.276335 \\
\hline H & -0.908763 & -2.899702 & -1.039920 & C & -0.195102 & 0.427457 & -0.538248 \\
\hline H & -1.198451 & 1.854351 & -0.453094 & 0 & -0.164036 & 1.119285 & 0.460154 \\
\hline H & 0.337075 & 4.467925 & -0.838151 & C & -4.940537 & -0.221868 & -1.164332 \\
\hline H & -1.348823 & 4.160207 & -1.239080 & $C$ & -3.803683 & -2.383577 & -0.773532 \\
\hline H & -0.060788 & 3.338017 & -2.130946 & C & -0.945135 & 0.250205 & -3.615445 \\
\hline
\end{tabular}




\begin{tabular}{|c|c|c|c|c|c|c|c|}
\hline C & -0.747475 & -2.063154 & -2.638186 & $\mathbf{H}$ & 0.482342 & -0.932768 & 1.673001 \\
\hline C & -3.575481 & 2.460243 & 0.668601 & $\mathbf{H}$ & 0.171580 & -2.068778 & 2.981623 \\
\hline C & -5.078096 & 2.786088 & 0.607903 & $\mathbf{H}$ & -1.147906 & -4.327971 & 1.428293 \\
\hline 0 & -1.300833 & -2.172262 & 1.380127 & $\mathbf{H}$ & -2.818160 & -3.753257 & 1.505842 \\
\hline C & -1.798591 & -3.550867 & 1.833568 & $\mathbf{H}$ & -1.774164 & -3.641685 & 2.920762 \\
\hline 0 & 0.887118 & 0.027760 & -1.238454 & $\mathbf{H}$ & -3.136814 & 3.212685 & 1.331482 \\
\hline C & 2.166759 & 0.149323 & -0.742017 & H & -3.079046 & 3.738927 & -0.976844 \\
\hline C & 2.740075 & 1.399808 & -0.413926 & $\mathbf{H}$ & -1.825671 & 2.556706 & -0.612813 \\
\hline C & 4.065754 & 1.425533 & 0.118548 & $\mathbf{H}$ & -3.290654 & 2.073534 & -1.481193 \\
\hline$C$ & 4.784994 & 0.167697 & 0.309353 & $\mathbf{H}$ & -5.218953 & 3.811821 & 0.260700 \\
\hline C & 4.200771 & -1.052749 & -0.099352 & $\mathbf{H}$ & -5.547388 & 2.697260 & 1.587872 \\
\hline C & 2.841008 & -1.105349 & -0.671237 & $\mathbf{H}$ & -5.613223 & 2.128891 & -0.074899 \\
\hline C & 4.637117 & 2.669826 & 0.411603 & $\mathbf{H}$ & -1.205881 & -0.129999 & -4.605342 \\
\hline C & 3.962853 & 3.857461 & 0.188198 & $\mathbf{H}$ & -1.378727 & 1.246779 & -3.509545 \\
\hline C & 2.679259 & 3.831018 & -0.364276 & $\mathbf{H}$ & 0.137304 & 0.330855 & -3.550918 \\
\hline C & 2.081281 & 2.627316 & -0.663951 & $\mathbf{H}$ & 0.302035 & -1.968896 & -2.364183 \\
\hline C & 6.071386 & 0.114505 & 0.879059 & H & -1.195074 & -2.810315 & -1.984366 \\
\hline C & 6.746141 & -1.081409 & 1.026993 & $\mathbf{H}$ & -0.822776 & -2.428923 & -3.664579 \\
\hline C & 6.160378 & -2.280709 & 0.609248 & $\mathbf{H}$ & 6.550350 & 1.022006 & 1.217725 \\
\hline C & 4.897475 & -2.258221 & 0.054020 & H & 7.734123 & -1.086061 & 1.471185 \\
\hline 0 & 2.299759 & -2.180619 & -1.003531 & $\mathbf{H}$ & 6.691762 & -3.216993 & 0.726105 \\
\hline$C$ & -2.900748 & 2.702383 & -0.683438 & H & 4.404422 & -3.163335 & -0.274614 \\
\hline C & 0.130941 & -1.937299 & 1.898110 & $\mathbf{H}$ & 1.098521 & 2.620571 & -1.109009 \\
\hline H & -3.275053 & -1.766416 & 41 & $\mathbf{H}$ & 65 & 952 & -0.563620 \\
\hline $\mathbf{H}$ & -3.436751 & -0.013948 & -3.211062 & $\mathbf{H}$ & 4.436832 & 4.801120 & 0.426004 \\
\hline $\mathbf{H}$ & -5.289502 & -0.190362 & -0.132954 & $\mathbf{H}$ & 5.639827 & 2.715844 & 0.811949 \\
\hline H & -4.877917 & 0.791406 & -1.549985 & A8 & & & \\
\hline $\mathbf{H}$ & -5.680696 & -0.762290 & -1.756131 & 78 & & & \\
\hline H & -4.135151 & -2.385425 & 0.263619 & scf & e: -1638 & .391922 & \\
\hline $\mathrm{H}$ & -4.577685 & -2.858447 & -1.377494 & C & 2.228734 & 1.123696 & 1.763049 \\
\hline H & -2.900369 & -2.980254 & -0.851729 & $\mathbf{N}$ & 1.860174 & 0.234070 & 0.610715 \\
\hline H & 1 & 73 & 88 & C & 99 & 80 & 0 \\
\hline H & -3.399790 & 0.278898 & 4.714794 & C & 0.620075 & -0.669990 & 2.399080 \\
\hline$\pi$ & -3.988373 & 2.115033 & 3.194938 & C & 1.272620 & 0.638969 & 2.878896 \\
\hline H & -1.240735 & -2.186611 & 3 & C & 1.993044 & 2.60 & 1.4 \\
\hline $\mathbf{H}$ & 0.815763 & -2.647686 & 1.433522 & C & 3.693617 & 0.958411 & 2.1610 \\
\hline
\end{tabular}




\begin{tabular}{|c|c|c|c|c|c|c|c|}
\hline C & 2.507844 & 0.351511 & -0.680677 & $\mathbf{H}$ & 2.270978 & 3.202643 & 2.340073 \\
\hline C & 3.667592 & -0.425063 & -0.945197 & $\mathbf{H}$ & 4.347240 & 1.252393 & 1.341481 \\
\hline C & 4.335114 & -0.258677 & -2.158241 & $\mathbf{H}$ & 3.912607 & 1.607309 & 3.010681 \\
\hline C & 3.885426 & 0.622150 & -3.123502 & $\mathbf{H}$ & 3.926909 & -0.064628 & 2.445208 \\
\hline C & 2.739850 & 1.353987 & -2.879418 & $\mathbf{H}$ & 5.220581 & -0.849133 & -2.352785 \\
\hline C & 2.039953 & 1.246360 & -1.676237 & $\mathbf{H}$ & 4.416833 & 0.728686 & -4.061382 \\
\hline C & 4.244952 & -1.478047 & -0.010918 & $\mathbf{H}$ & 2.373094 & 2.031247 & -3.639102 \\
\hline C & 4.241081 & -2.873387 & -0.659095 & $\mathbf{H}$ & 3.607059 & -1.520276 & 0.864341 \\
\hline C & 5.682437 & -1.150941 & 0.427936 & $\mathbf{H}$ & 4.541721 & -3.623131 & 0.077203 \\
\hline 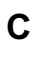 & 0.777085 & 2.083949 & -1.563429 & $\mathbf{H}$ & 3.257079 & -3.136887 & -1.032758 \\
\hline$c$ & 1.004449 & 3.566218 & -1.886643 & $\mathbf{H}$ & 4.954312 & -2.921672 & -1.484964 \\
\hline C & -0.330981 & 1.504662 & -2.456713 & $\mathbf{H}$ & 6.017871 & -1.873572 & 1.175889 \\
\hline C & -0.770093 & -0.865585 & 3.006473 & $\mathbf{H}$ & 5.778823 & -0.154546 & 0.853235 \\
\hline$C$ & 1.478825 & -1.888183 & 2.760409 & $\mathbf{H}$ & 6.369799 & -1.215843 & -0.417923 \\
\hline$c$ & 0.396410 & -1.664482 & 0.030715 & $\mathbf{H}$ & 0.424152 & 2.024787 & -0.546437 \\
\hline$C$ & 1.271380 & -2.434285 & -0.231160 & $\mathbf{H}$ & 0.093537 & 4.132327 & -1.677935 \\
\hline C & -0.482415 & 0.580276 & 0.610946 & $\mathbf{H}$ & 1.810558 & 3.988326 & -1.285037 \\
\hline 0 & -0.871983 & -1.979820 & -0.340470 & $\mathbf{H}$ & 1.253387 & 3.727071 & -2.937137 \\
\hline c & -1.719234 & 0.148175 & 0.284351 & $\mathbf{H}$ & -1.270421 & 2.038018 & -2.295894 \\
\hline c & -1.934742 & -1.105599 & -0.169522 & $\mathbf{H}$ & -0.503695 & 0.449152 & -2.245311 \\
\hline c & -3.228961 & -1.588868 & -0.518052 & $\mathbf{H}$ & -0.067761 & 1.589233 & -3.513479 \\
\hline c & -4.334176 & -0.700952 & -0.410720 & $\mathbf{H}$ & -0.667439 & -0.999259 & 4.085307 \\
\hline C & -4.111952 & 0.661894 & 0.042435 & $\mathbf{H}$ & -1.418979 & -0.009061 & 2.838414 \\
\hline c & -2.801197 & 1 & 0 & $\mathbf{H}$ & 68 & 92 & 2.613804 \\
\hline C & -5.147805 & 1.610080 & 0.152542 & $\mathbf{H}$ & 1.026553 & -2.8 & 2.412756 \\
\hline C & -4.905885 & 2.896013 & 0.585671 & $\mathbf{H}$ & 2.477610 & -1.828936 & 2.339597 \\
\hline c & -3.607852 & 3.293716 & 3988 & $\mathbf{H}$ & 1.56 & 1756 & 940 \\
\hline C & -2.569857 & 2.394734 & 0.840517 & $\mathbf{H}$ & -6.158337 & 1.332917 & -0.110747 \\
\hline C & -3.422722 & -2.910197 & -0.967140 & $\pi$ & -5.724347 & 3.601085 & 0.656665 \\
\hline C & -4.682704 & -3.355180 & -1.297025 & $\mathbf{H}$ & -3.422685 & 4.304345 & 1.274952 \\
\hline C & -5.781782 & -2.492250 & -1.189404 & $\mathbf{H}$ & -1.562816 & 2.683445 & 1.104960 \\
\hline c & -5.60 & 5 & 99 & $\mathbf{H}$ & 41 & 82 & 995 \\
\hline r & 1.801112 & 0.490709 & 3.820483 & H & -4.823829 & -4.372107 & -1.640436 \\
\hline$r$ & 0.497234 & 1.385694 & 3.047539 & H & -6.772702 & -2.843140 & -1.447792 \\
\hline H & 2.605631 & 2.940527 & 0.627689 & $\mathbf{H}$ & -6.470222 & -0.551289 & -0.682358 \\
\hline $\mathrm{H}$ & 0.948828 & 2.810040 & 1.238241 & A9 & & & \\
\hline
\end{tabular}




\begin{tabular}{|c|c|c|c|c|c|c|c|}
\hline 7 & & & & C & -1.729265 & 2.690646 & -0.793849 \\
\hline scf & done: -1638 & .355144 & & C & -3.689102 & -2.650011 & -0.416651 \\
\hline C & 3.094591 & -1.166988 & 1.314101 & C & -4.984100 & -2.901811 & -0.028829 \\
\hline $\mathbf{N}$ & 1.985861 & -0.555389 & 0.453437 & C & -5.845184 & -1.833225 & 0.267760 \\
\hline C & 1.307406 & -1.442336 & -0.216652 & C & -5.399513 & -0.532046 & 0.176178 \\
\hline C & 1.727838 & -2.863339 & 0.137162 & H & 3.485929 & -3.310439 & 1.372900 \\
\hline C & 2.637836 & -2.627798 & 1.365386 & H & 2.067558 & -2.798178 & 2.278962 \\
\hline C & 3.167107 & -0.521622 & 2.689986 & H & 3.382385 & 0.544017 & 2.622274 \\
\hline C & 4.446982 & -0.995876 & 0.624928 & H & 2.248586 & -0.659272 & 3.250957 \\
\hline C & 1.834354 & 0.893251 & 0.414461 & H & 3.975369 & -0.997535 & 3.247174 \\
\hline C & 2.569686 & 1.614171 & -0.547545 & H & 4.725142 & 0.053919 & 0.579833 \\
\hline C & 2.545362 & 3.004968 & -0.479755 & H & 5.201904 & -1.519021 & 1.213349 \\
\hline C & 1.782316 & 3.664002 & 0.467556 & H & 4.456156 & -1.403878 & -0.382254 \\
\hline$c$ & 1.001337 & 2.930744 & 1.339741 & H & 3.105379 & 3.576305 & -1.207425 \\
\hline C & 0.997900 & 1.532335 & 1.348482 & H & 1.760560 & 4.746205 & 0.497090 \\
\hline C & 3.275870 & 0.981124 & -1.738362 & H & 0.338739 & 3.452787 & 2.016995 \\
\hline C & 2.527845 & 1.329860 & -3.037612 & H & 3.234549 & -0.100418 & -1.641370 \\
\hline c & 4.744749 & 1.411668 & -1.863305 & H & 2.990036 & 0.807329 & -3.877250 \\
\hline C & -0.036480 & 0.933345 & 2.318825 & H & 1.487309 & 1.024587 & -2.985105 \\
\hline C & -0.396957 & -0.550448 & 2.247203 & H & 2.578042 & 2.403456 & -3.234772 \\
\hline c & 0.257818 & 1.320495 & 3.780571 & H & 5.226563 & 0.852347 & -2.667662 \\
\hline C & 0.545491 & -3.769577 & 0.517421 & H & 5.314389 & 1.247811 & -0.948924 \\
\hline C & 2.494834 & 2 & 57 & H & 2 & 20 & 3648 \\
\hline C & 0.387243 & -1.140068 & -1.404211 & H & -0.954477 & 1.459911 & 2.039334 \\
\hline 0 & 1.021612 & -1.427801 & -2.434633 & H & -1.255766 & -0.723456 & 2.898141 \\
\hline 0 & -0.116593 & 0.279394 & -1.319991 & H & -0.694516 & -0.857282 & 1.250571 \\
\hline 0 & -0.910438 & -1.926817 & -1.155504 & H & 0.401802 & -1.202785 & 2.593516 \\
\hline C & -1.430596 & 0.247223 & -0.989151 & H & -0.581939 & 1.028311 & 65 \\
\hline C & -1.890019 & -1.024796 & -0.900336 & H & 0.408492 & 2.392360 & 3.899871 \\
\hline$c$ & -3.219023 & -1.324990 & -0.518331 & H & 1.149654 & 0.820302 & 4.158312 \\
\hline C & -4.080591 & -0.225432 & -0.213899 & $\mathbf{H}$ & 0.949580 & -4.697312 & 0.929440 \\
\hline C & -3.580425 & 1.137660 & -0.301688 & H & -0.091982 & -3.307984 & 1.270492 \\
\hline C & -2.233088 & 1.376580 & -0.712699 & H & -0.067201 & -4.002023 & -0.348095 \\
\hline C & -4.365534 & 2.266250 & 0.008386 & H & 1.847841 & -3.640898 & -1.890706 \\
\hline C & -3.858668 & 3.545913 & -0.072018 & H & 3.353622 & -2.933786 & -1.340201 \\
\hline C & -2.530828 & 290 & -0.476102 & H & 2.846866 & -4.502802 & -0.691964 \\
\hline
\end{tabular}




\begin{tabular}{|c|c|c|c|c|c|c|c|}
\hline $\mathbf{H}$ & -5.391514 & 2.135456 & 0.322329 & $\mathbf{H}$ & -4.044060 & 0.411490 & -0.750001 \\
\hline $\mathbf{H}$ & -4.491082 & 4.389307 & 0.175201 & $\mathbf{H}$ & -2.662272 & 0.968523 & -2.495405 \\
\hline $\mathbf{H}$ & -2.141039 & 4.769683 & -0.539943 & $\mathbf{H}$ & -1.705304 & 2.002359 & -1.451522 \\
\hline H & -0.703550 & 2.832740 & -1.104132 & $\mathbf{H}$ & -2.151927 & -1.382724 & -2.768419 \\
\hline $\mathbf{H}$ & -3.011249 & -3.458206 & -0.657225 & $\mathbf{H}$ & -0.797106 & -2.146421 & -1.964436 \\
\hline $\mathbf{H}$ & -5.341996 & -3.921248 & 0.043621 & $\mathbf{H}$ & -2.140966 & -2.643388 & -0.127628 \\
\hline H & -6.866309 & -2.030586 & 0.568807 & $\mathbf{H}$ & -3.514523 & -1.948702 & -0.971704 \\
\hline $\mathbf{H}$ & -6.088158 & 0.267717 & 0.409632 & $\mathbf{H}$ & 0.846788 & -0.366783 & -2.784205 \\
\hline A10 & & & & $\mathbf{H}$ & -0.514752 & 0.298039 & -3.695950 \\
\hline 58 & & & & $\mathbf{H}$ & 0.425058 & 1.337645 & -2.619808 \\
\hline scf & done: -1026 & .738247 & & $\mathbf{H}$ & -3.386546 & -0.212028 & 2.356323 \\
\hline C & 1.921362 & -1.079476 & 0.002522 & $\mathbf{H}$ & -4.443202 & -1.091624 & 1.249254 \\
\hline C & 1.152020 & 0.094301 & -0.115946 & $\mathbf{H}$ & -3.074113 & -1.912627 & 2.005101 \\
\hline C & 1.755884 & 1.359712 & 0.024726 & $\mathbf{H}$ & -3.526961 & 2.764915 & -0.032746 \\
\hline C & 3.135555 & 1.430353 & 0.209369 & $\mathbf{H}$ & -3.974334 & 1.733831 & 1.323361 \\
\hline C & 3.905932 & 0.279788 & 0.280312 & $\mathbf{H}$ & -2.276242 & 2.135182 & 1.044482 \\
\hline C & 3.297931 & -0.962832 & 0.190727 & $\mathbf{H}$ & 3.611551 & 2.397522 & 0.311836 \\
\hline $\mathbf{N}$ & -0.258302 & 0.024726 & -0.311769 & $\mathbf{H}$ & 4.977473 & 0.351117 & 0.421901 \\
\hline C & -0.949059 & -0.010657 & -1.620898 & H & 3.901812 & -1.858197 & 0.270888 \\
\hline C & -2.112443 & 0.995426 & -1.551731 & $\mathbf{H}$ & -0.081786 & 2.352091 & -0.239835 \\
\hline C & -3.057654 & 0.679937 & -0.358477 & H & 0.202647 & 4.072049 & 1.505790 \\
\hline C & -2.533391 & -0.585048 & 0.382025 & H & 0.465919 & 2.453867 & 2.171914 \\
\hline C & -1.091658 & -0.311030 & 0.782595 & H & 1.844163 & 3.500476 & 1.827806 \\
\hline C & -2.493259 & -1.745969 & -0.639277 & H & 0.756601 & 4.548035 & -0.949056 \\
\hline C & -1.580866 & -1.401313 & -1.837469 & H & 1.489917 & 3.291794 & 54422 \\
\hline C & 0.014650 & 0.336074 & -2.742971 & H & 2.423747 & 4.054194 & -0.668608 \\
\hline C & -0.686730 & -0.358277 & 33 & H & 855 & 282 & 5206 \\
\hline 0 & -0.350998 & -0.441832 & 3.156316 & H & 1.265674 & -4.218308 & -1.326774 \\
\hline C & -3.407253 & -0.967962 & 1.571210 & H & 1.594364 & -2.713982 & -2.197293 \\
\hline C & -3.220709 & 1.894668 & 0.551673 & H & 2.852381 & -3.454434 & -1.210004 \\
\hline C & 0.928644 & 2.630187 & 0.048549 & H & 1.011355 & -4.194546 & 1.222025 \\
\hline C & 1.430890 & 3.688677 & -0.939280 & H & 1.172239 & -2.675549 & 2.114499 \\
\hline C & 1.294738 & -2.459361 & -0.050388 & H & 2.596095 & -3.441686 & 1.405267 \\
\hline C & 1.534543 & -3.235787 & 1.251755 & \multicolumn{4}{|l|}{ A11 } \\
\hline C & 0.855929 & 3.196604 & 1.474589 & \multicolumn{4}{|c|}{82} \\
\hline$c$ & 1.780038 & -3.256062 & -1.268208 & \multicolumn{4}{|c|}{ scf done: -1715.841315} \\
\hline
\end{tabular}




\begin{tabular}{|c|c|c|c|c|c|c|c|}
\hline$C$ & 1.343174 & 1.486735 & 2.539963 & C & -5.867376 & -2.366987 & -1.454734 \\
\hline C & 2.423123 & 0.762948 & 1.708467 & C & -4.983368 & 2.792021 & 0.901456 \\
\hline $\mathbf{N}$ & 1.805819 & 0.210878 & 0.461062 & C & -5.226435 & 1.564605 & 0.323947 \\
\hline C & 0.561504 & -0.425233 & 0.660765 & C & -4.763815 & -3.193125 & -1.709224 \\
\hline C & 0.429976 & -0.832993 & 2.177818 & C & -3.494863 & -2.762316 & -1.396311 \\
\hline$C$ & 0.240044 & 0.495298 & 2.945955 & H & 1.820654 & 1.924128 & 3.418803 \\
\hline$C$ & 1.748477 & -1.438294 & 2.753580 & $\mathbf{H}$ & 0.933532 & 2.309675 & 1.955758 \\
\hline C & 2.910595 & -0.437676 & 2.533276 & H & -0.747858 & 0.907407 & 2.759090 \\
\hline C & 2.322205 & 0.531700 & -0.853856 & H & 0.292157 & 0.264408 & 4.011569 \\
\hline $\mathrm{C}$ & 1.873185 & 1.671433 & -1.562050 & $\mathbf{H}$ & 1.547112 & -1.481403 & 3.827820 \\
\hline C & 2.394750 & 1.930069 & -2.831165 & H & 3.298564 & -0.082002 & 3.491173 \\
\hline C & 3.367404 & 1.126378 & -3.394248 & H & 3.738425 & -0.919329 & 2.017458 \\
\hline C & 3.844413 & 0.044407 & -2.676681 & H & 2.037977 & 2.792356 & -3.379166 \\
\hline C & 3.346754 & -0.272726 & -1.413803 & H & 3.760796 & 1.348634 & -4.378749 \\
\hline C & 0.873944 & 2.683892 & -1.026786 & H & 4.622432 & -0.573931 & -3.104431 \\
\hline C & 1.474954 & 4.095291 & -0.944452 & $\mathbf{H}$ & 0.597810 & 2.382093 & -0.025584 \\
\hline C & 3.981110 & -1.458197 & -0.705876 & H & 0.761898 & 4.777248 & -0.474639 \\
\hline C & 3.999457 & -2.723517 & -1.576134 & H & 2.394464 & 4.111290 & -0.357840 \\
\hline C & 3.553217 & 1.730264 & 1.395220 & $\mathbf{H}$ & 1.709116 & 4.494137 & -1.933221 \\
\hline C & 2.109653 & -2.865859 & 2.343046 & H & 3.375715 & -1.670669 & 0.164795 \\
\hline C & -0.752485 & -1.763944 & 2.444487 & H & 4.299720 & -3.582228 & -0.970906 \\
\hline C & 0.328307 & -1.623086 & -0.292090 & $\mathbf{H}$ & 3.017669 & -2.931250 & -1.993398 \\
\hline 0 & 1.181861 & -2.402683 & -0.592795 & $\mathbf{H}$ & 4.717334 & -2.636428 & -2.394789 \\
\hline C & 5.412787 & -1.144121 & -0.242685 & $\mathbf{H}$ & 4.036082 & 2.019315 & 2.329797 \\
\hline C & -0.406250 & 2.704296 & -1.873879 & H & 4.304275 & 1.293053 & 0.743933 \\
\hline 0 & -0.517729 & 0.579142 & 758 & $\mathbf{H}$ & 717 & 2.631793 & 0.914234 \\
\hline 0 & -0.924815 & -1.849518 & -0.772571 & H & 3.005304 & -3.174579 & 2.887565 \\
\hline C & -1.994652 & -1.021812 & -0.486637 & $\mathbf{H}$ & 1.316369 & -3.570385 & 2.597632 \\
\hline C & -1.772854 & 0.178027 & 0.091626 & $\mathbf{H}$ & 2.310334 & -2.959852 & 1.280263 \\
\hline C & -2.860279 & 1.065345 & 0.373670 & H & -0.700780 & -2.686484 & 1.865901 \\
\hline C & -4.181706 & 0.662427 & 0.041410 & H & -0.754415 & -2.041182 & 3.500515 \\
\hline C & -4.406887 & -0.643599 & -0.555555 & H & -1.703668 & -1.280159 & 2.230102 \\
\hline C & -3.296474 & -1.492475 & -0.818983 & $\mathbf{H}$ & 5.838179 & -2.010136 & 0.270512 \\
\hline C & -2.628281 & 2.320708 & 0.967114 & $\mathbf{H}$ & 5.454307 & -0.298585 & 0.442 \\
\hline C & -3.674887 & 3.174572 & 1.228708 & H & 6.056721 & -0.911636 & -1.093728 \\
\hline C & -5.687788 & -1.122103 & -0.891183 & $\mathbf{H}$ & -1.156726 & 3.355304 & -1.4213 \\
\hline
\end{tabular}




\begin{tabular}{|c|c|c|c|c|c|c|c|}
\hline $\mathbf{H}$ & -0.835692 & 1.707947 & -1.965547 & C & 0.694309 & 0.076183 & 2.459909 \\
\hline $\mathrm{H}$ & -0.204798 & 3.076006 & -2.880847 & C & 1.553455 & -2.203616 & 1.907399 \\
\hline H & -1.612506 & 2.600676 & 1.205907 & C & 0.647913 & -1.426678 & 2.876322 \\
\hline $\mathbf{H}$ & -3.489152 & 4.139067 & 1.683929 & C & -0.409836 & 0.894747 & 3.123916 \\
\hline $\mathbf{H}$ & -6.556233 & -0.507073 & -0.703801 & C & 3.652476 & -2.045674 & 0.546947 \\
\hline $\mathbf{H}$ & -6.865353 & -2.706465 & -1.701032 & C & 2.311535 & -0.058284 & -0.988428 \\
\hline $\mathbf{H}$ & -5.808832 & 3.462641 & 1.103778 & C & 3.308354 & 0.920158 & -1.234227 \\
\hline $\mathbf{H}$ & -6.245115 & 1.297837 & 0.082159 & C & 3.736059 & 1.136280 & -2.543587 \\
\hline $\mathbf{H}$ & -4.909230 & -4.169950 & -2.152699 & C & 3.217837 & 0.418151 & -3.606038 \\
\hline $\mathbf{H}$ & -2.634379 & -3.387073 & -1.589567 & C & 2.268551 & -0.555167 & -3.360319 \\
\hline A12 & & & & C & 1.814447 & -0.825019 & -2.068108 \\
\hline 82 & & & & C & -0.716629 & -2.076834 & 3.081390 \\
\hline scf & done: -1715 & .843247 & & C & 3.992907 & 1.737623 & -0.150642 \\
\hline 0 & -0.474651 & -0.650809 & 0.395295 & C & 5.448096 & 1.286048 & 0.055145 \\
\hline C & 0.656475 & 0.194330 & 0.889652 & C & 3.966201 & 3.244470 & -0.447333 \\
\hline C & 0.408714 & 1.672983 & 0.510960 & $\mathbf{H}$ & 3.485135 & -1.081606 & 3.236311 \\
\hline 0 & 1.253789 & 2.513159 & 0.615845 & $\mathbf{H}$ & 4.064543 & 0.125183 & 2.109358 \\
\hline C & -1.698689 & -0.135995 & 0.151311 & $\mathbf{H}$ & 2.263321 & 1.574761 & 2.540035 \\
\hline C & -1.898338 & 1.195358 & 0.032514 & $\mathbf{H}$ & 2.078193 & 0.635039 & 4.008823 \\
\hline C & -3.180359 & 1.772125 & -0.198293 & $\mathbf{H}$ & 1.131559 & -1.437668 & 3.858369 \\
\hline C & -4.294175 & 0.903812 & -0.354304 & $\mathbf{H}$ & 2.074357 & -3.005792 & 2.435309 \\
\hline C & -4.088650 & -0.533129 & -0.292221 & $\mathbf{H}$ & 0.964948 & -2.663850 & 1.113601 \\
\hline C & -2.788160 & -1.049617 & -0.046522 & $\mathbf{H}$ & 4.493965 & 1.885256 & -2.730775 \\
\hline C & -5.555842 & 1.490542 & -0.569017 & $\mathbf{H}$ & 3.560186 & 0.608624 & -4.615941 \\
\hline C & -5.712619 & 2.858260 & -0.634293 & $\mathbf{H}$ & 1.877517 & -1.134367 & -4.186567 \\
\hline C & -4.604071 & 3.703253 & -0.486857 & $\mathbf{H}$ & 3.445186 & 1.583222 & 0.769542 \\
\hline C & -3.354237 & 3.168568 & -0.272452 & $\mathbf{H}$ & 5.910394 & 1.862187 & 0.860585 \\
\hline 0 & -0.833074 & 2.071818 & 0.141608 & $\mathbf{H}$ & 5.523782 & 0.230214 & 0.313368 \\
\hline C & -5.133298 & -1.459005 & -0.484771 & $\mathbf{H}$ & 6.037954 & 1.446814 & -0.849922 \\
\hline C & -4.910799 & -2.817977 & -0.446045 & $\mathbf{H}$ & 4.230089 & -2.614711 & 1.277069 \\
\hline C & -3.620850 & -3.315383 & -0.217045 & $\mathbf{H}$ & 3.202971 & -2.749022 & -0.152242 \\
\hline C & -2.576924 & -2.441395 & -0.020796 & $\mathbf{H}$ & 4.336536 & -1.411064 & -0.010049 \\
\hline $\mathbf{N}$ & 1.866550 & -0.312183 & 0.363339 & $\mathbf{H}$ & -0.577094 & -3.117199 & 3.387046 \\
\hline C & 2.588640 & -1.247010 & 1.280372 & $\mathbf{H}$ & -1.282895 & -1.581951 & 3.871510 \\
\hline C & 3.174311 & -0.407429 & 2.434327 & $\mathbf{H}$ & -1.320778 & -2.074051 & 2.181455 \\
\hline C & 2.085998 & 0.570516 & 2.918812 & $\mathbf{H}$ & -1.401630 & 0.620797 & 2.765918 \\
\hline
\end{tabular}




\begin{tabular}{|c|c|c|c|c|c|c|c|}
\hline $\mathbf{H}$ & -0.387961 & 0.725140 & 4.201688 & 0 & -0.982705 & 1.149359 & 0.026103 \\
\hline H & -0.267375 & 1.964254 & 2.960968 & C & -2.250157 & 0.691886 & -0.145200 \\
\hline $\mathbf{H}$ & 4.323909 & 3.797716 & 0.424120 & C & -2.285513 & -0.651251 & -0.345397 \\
\hline $\mathbf{H}$ & 2.958245 & 3.584762 & -0.671142 & 0 & -1.041105 & -1.203710 & -0.315322 \\
\hline $\mathbf{H}$ & 4.617403 & 3.500729 & -1.285917 & 0 & 0.418256 & 0.116420 & -1.570594 \\
\hline H & -1.576303 & -2.811945 & 0.142603 & C & 2.813681 & 0.273675 & -0.718745 \\
\hline H & -3.445255 & -4.383418 & -0.197865 & C & 3.023689 & 1.615119 & -1.049754 \\
\hline $\mathbf{H}$ & -6.427254 & 0.862291 & -0.684716 & C & 3.824510 & 1.881186 & -2.158552 \\
\hline $\mathbf{H}$ & -6.695893 & 3.279428 & -0.800539 & C & 4.378382 & 0.855256 & -2.908420 \\
\hline $\mathbf{H}$ & -5.735442 & -3.502174 & -0.600580 & C & 4.106085 & -0.464319 & -2.580676 \\
\hline $\mathbf{H}$ & -6.135089 & -1.102846 & -0.676301 & C & 3.314107 & -0.785199 & -1.481128 \\
\hline H & -4.730286 & 4.777100 & -0.541186 & C & -0.973799 & -0.522398 & 2.538862 \\
\hline $\mathbf{H}$ & -2.491194 & 3.808599 & -0.157374 & C & 0.715955 & -2.992583 & 2.110888 \\
\hline C & 0.824036 & -1.967697 & -1.924208 & C & 2.341617 & 2.762152 & -0.326530 \\
\hline C & -0.479272 & -1.662841 & -2.676310 & C & 3.342320 & 3.785092 & 0.225421 \\
\hline C & 1.412487 & -3.300954 & -2.409648 & C & 2.934350 & -2.231213 & -1.223403 \\
\hline $\mathbf{H}$ & -1.219927 & -2.443939 & -2.499071 & C & 2.003351 & -2.738243 & -2.336155 \\
\hline $\mathbf{H}$ & -0.908657 & -0.713456 & -2.358505 & C & 1.309373 & 3.429399 & -1.248659 \\
\hline $\mathbf{H}$ & -0.305776 & -1.605126 & -3.752833 & C & 4.152190 & -3.146485 & -1.052038 \\
\hline $\mathbf{H}$ & 0.708099 & -4.113419 & -2.214978 & $\mathbf{H}$ & 1.135303 & -1.708211 & 3.770790 \\
\hline $\mathbf{H}$ & 1.610885 & -3.286659 & -3.483128 & $\mathbf{H}$ & 3.117248 & -2.300098 & 1.685743 \\
\hline $\mathbf{H}$ & 2.350129 & -3.537593 & -1.905432 & $\mathbf{H}$ & 3.378730 & -1.635134 & 3.284436 \\
\hline $\mathbf{H}$ & 0.584826 & -2.070518 & -0.873047 & $\mathbf{H}$ & 3.149561 & 0.768148 & 3.700726 \\
\hline \multicolumn{4}{|c|}{ A13 } & $\mathbf{H}$ & 2.879272 & 1.912082 & 2.400770 \\
\hline \multicolumn{4}{|c|}{82} & $\mathbf{H}$ & 0.566789 & 389 & 533 \\
\hline \multicolumn{4}{|c|}{ scf done: -1715.811650} & $\mathbf{H}$ & 0.843856 & 0.663842 & 4.035932 \\
\hline $\mathbf{N}$ & 2.16 & -0.030 & 0.560429 & $\mathbf{H}$ & 76 & 86 & 065 \\
\hline C & 3.069226 & -0.150112 & 1.777777 & $\mathbf{H}$ & 5.103716 & -0.075001 & 2.371440 \\
\hline C & 4.541052 & 0.010943 & 1.440786 & $\mathbf{H}$ & 4.891666 & -0.757927 & 0.756479 \\
\hline C & 2.601142 & 0.927316 & 2.771284 & $\mathbf{H}$ & -1.492343 & 0.407888 & 2.325282 \\
\hline C & 1.090121 & 0.806359 & 2.983243 & $\mathbf{H}$ & -1.468548 & -1.318673 & 1.996541 \\
\hline C & 0.510605 & -0.414300 & 2.204785 & $\mathbf{H}$ & -1.061960 & -0.724769 & 3.608673 \\
\hline C & 0.892572 & -0.173729 & 0.762755 & $\mathbf{H}$ & 1.331774 & -3.835826 & 2.430953 \\
\hline C & 1.277291 & -1.692528 & 2.687169 & $\mathbf{H}$ & -0.303550 & -3.177567 & 2.445025 \\
\hline C & 2.777958 & -1.531758 & 2.379763 & $\mathbf{H}$ & 0.703828 & -2.975142 & 1.020019 \\
\hline C & -0.067936 & -0.029227 & -0.454083 & $\mathbf{H}$ & 4.499202 & -1.260736 & -3.199023 \\
\hline
\end{tabular}




\begin{tabular}{cllllllll} 
H & 4.999345 & 1.084220 & -3.765318 & C & -3.493515 & -1.365383 & -0.517228 \\
H & 3.999842 & 2.909025 & -2.448193 & C & -3.376123 & 2.876938 & 0.102596 \\
H & 2.362929 & -2.271713 & -0.299008 & C & -4.536664 & 3.612217 & 0.161398 \\
H & 1.650885 & -3.745669 & -2.101826 & C & -5.913679 & -1.346385 & -0.608298 \\
H & 1.144954 & -2.076228 & -2.440573 & C & -5.919421 & -2.711049 & -0.803348 \\
H & 2.529296 & -2.779859 & -3.292564 & C & -5.777721 & 2.971409 & 0.017990 \\
H & 3.829579 & -4.164964 & -0.825681 & C & -5.839931 & 1.609017 & -0.182786 \\
H & 4.804317 & -2.810689 & -0.242884 & H & -2.408184 & 3.350273 & 0.201498 \\
H & 4.751225 & -3.186391 & -1.963502 & H & -4.495398 & 4.683751 & 0.313051 \\
H & 1.784224 & 2.357075 & 0.516052 & H & -6.692121 & 3.549741 & 0.060823 \\
H & 2.818707 & 4.563380 & 0.784686 & H & -6.810904 & 1.146834 & -0.292321 \\
H & 4.073678 & 3.321696 & 0.891339 & C & -4.711892 & -3.425276 & -0.859729 \\
H & 3.894457 & 4.273282 & -0.579661 & C & -3.516244 & -2.760949 & -0.718478 \\
H & 0.755623 & 4.194474 & -0.699587 & H & -6.860318 & -0.825853 & -0.571598 \\
H & 0.604011 & 2.690483 & -1.624219 & H & -6.861299 & -3.232994 & -0.916657 \\
H & 1.800153 & 3.911007 & -2.097272 & H & -4.723863 & -4.496479 & -1.018639 \\
C & -3.422929 & 1.482550 & -0.100948 & H & -2.573552 & -3.289688 & -0.767417 \\
C & -4.677801 & 0.814563 & -0.246372 & & & & \\
C & -4.713726 & -0.623621 & -0.456361 & & & & \\
\hline
\end{tabular}


S5. NMR Spectra.

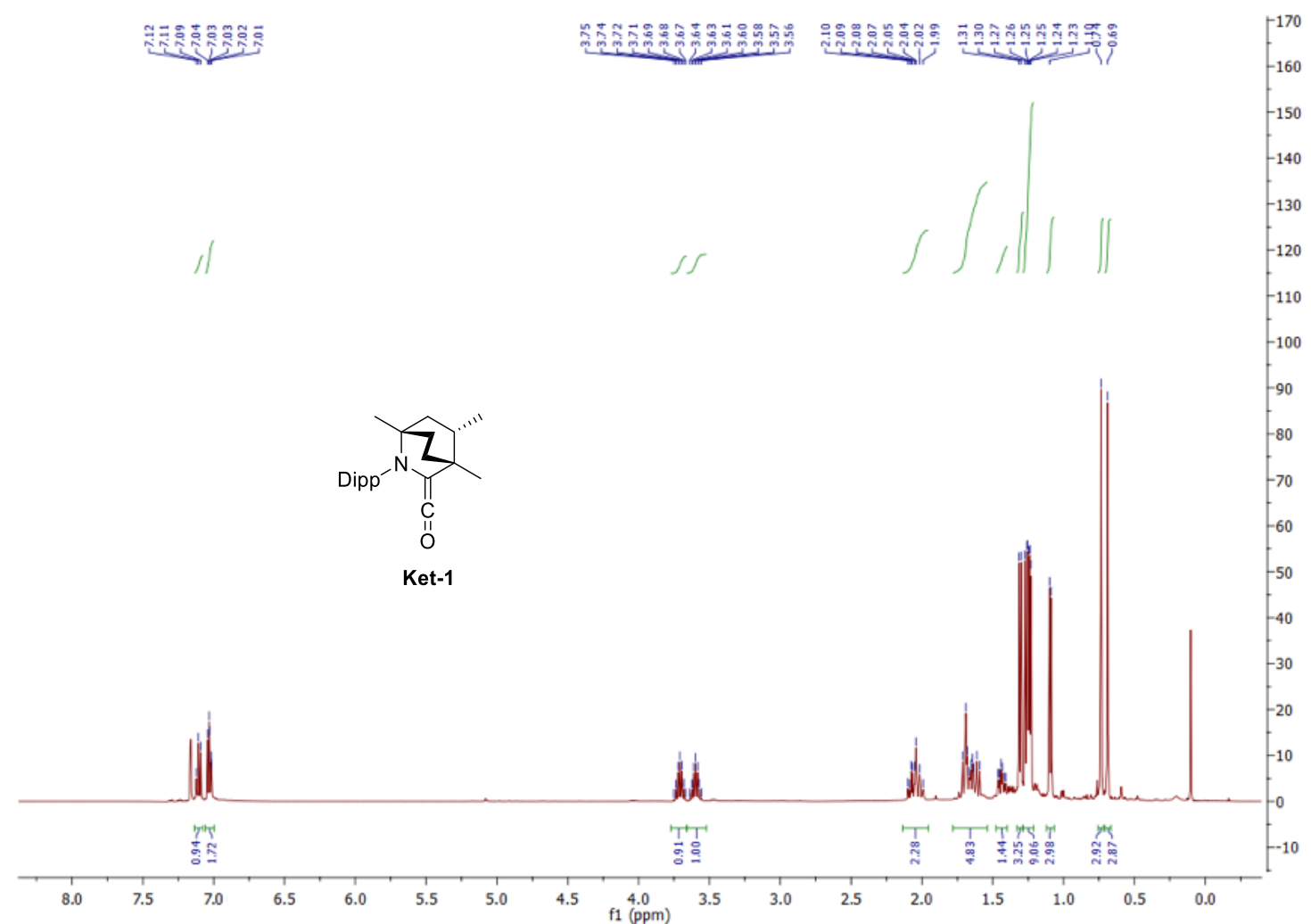

Fig. S28. ${ }^{1} \mathrm{H}$ NMR (500 MHz, $\left.\mathrm{C}_{6} \mathrm{D}_{6}\right)$ of Ket-1.

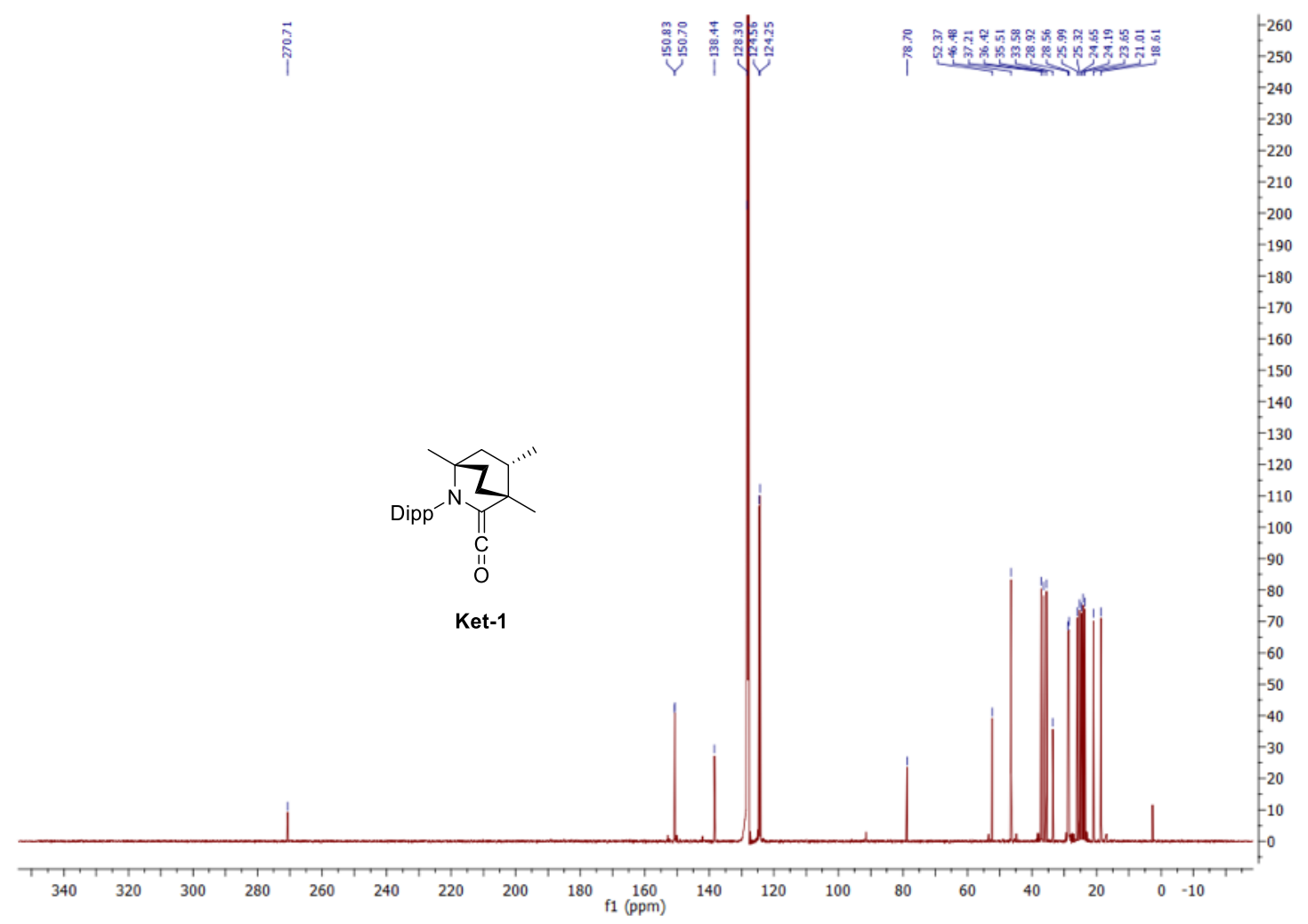

Fig. S29. ${ }^{13} \mathrm{C}\left\{{ }^{1} \mathrm{H}\right\}$ NMR (125.7 MHz, $\left.\mathrm{C}_{6} \mathrm{D}_{6}\right)$ of Ket-1. 


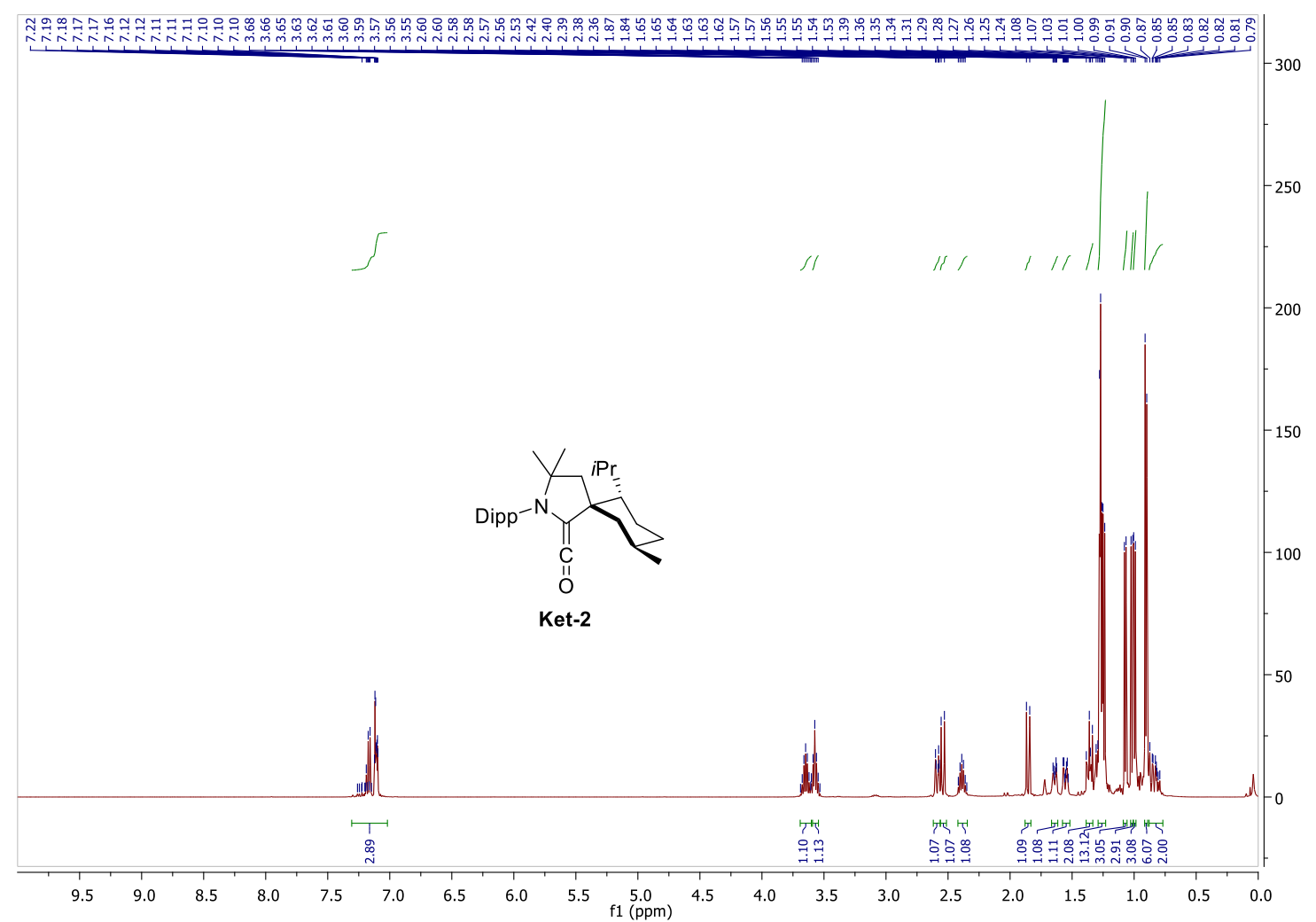

Fig. S30. ${ }^{1} \mathrm{H}$ NMR $\left(500 \mathrm{MHz}, \mathrm{THF}-\mathrm{d}_{8}\right)$ of Ket-2.

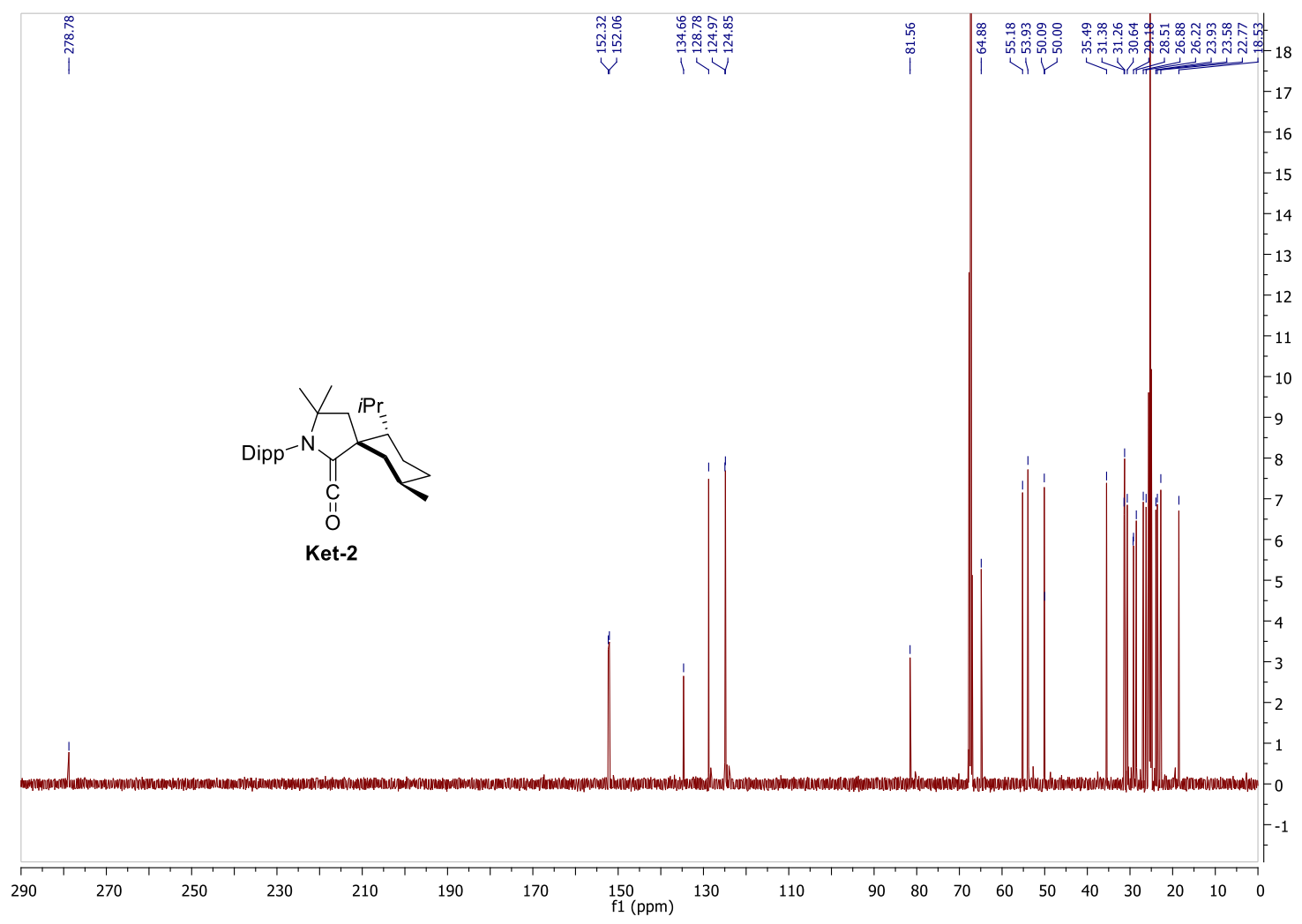

Fig. S31. ${ }^{13} \mathrm{C}\left\{{ }^{1} \mathrm{H}\right\}$ NMR (125.7 MHz, THF-d 8 ) of Ket-2. 


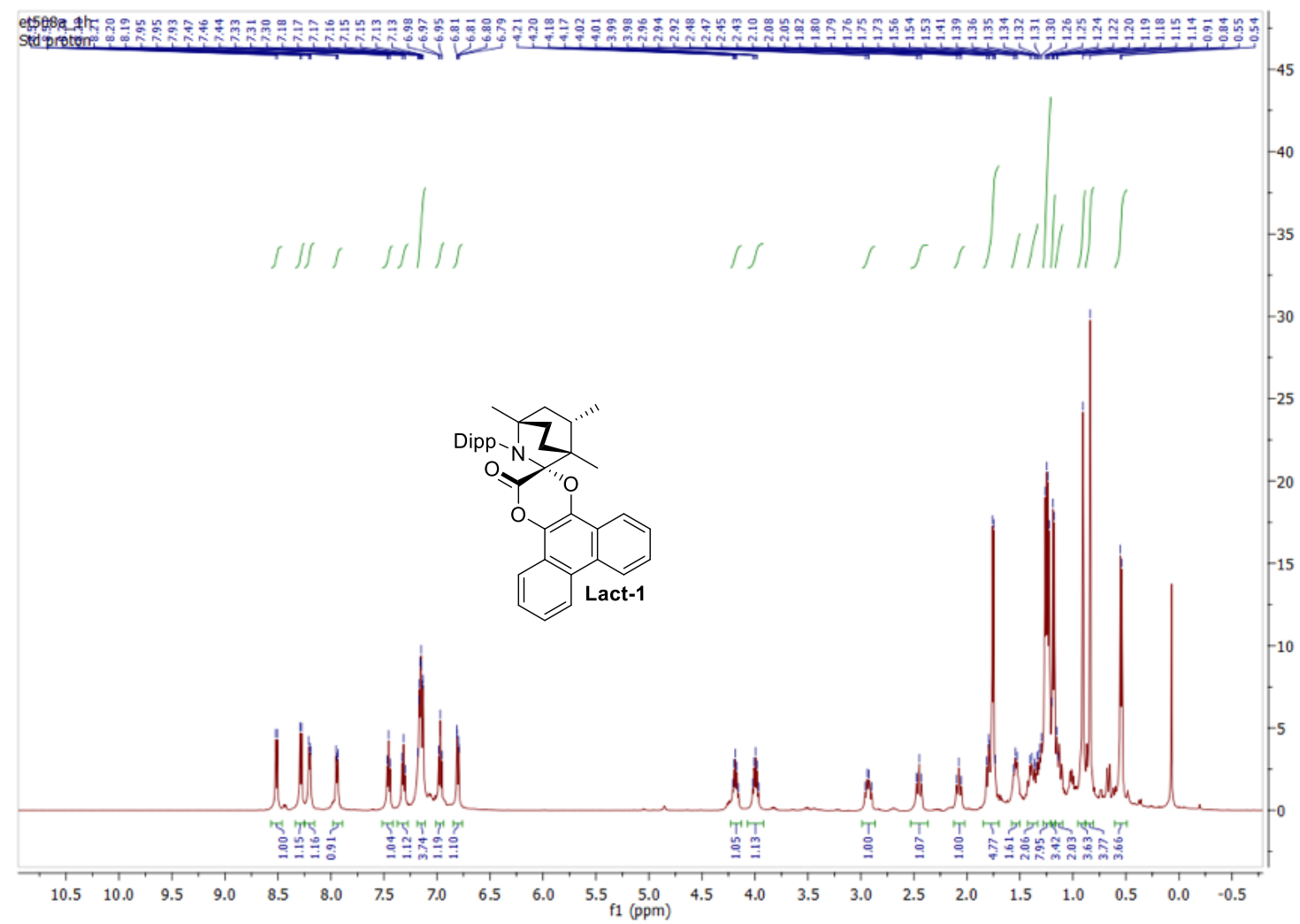

Fig. S32. ${ }^{1} \mathrm{H}$ NMR $\left(500 \mathrm{MHz}, \mathrm{C}_{6} \mathrm{D}_{6}\right)$ of Lact-1.

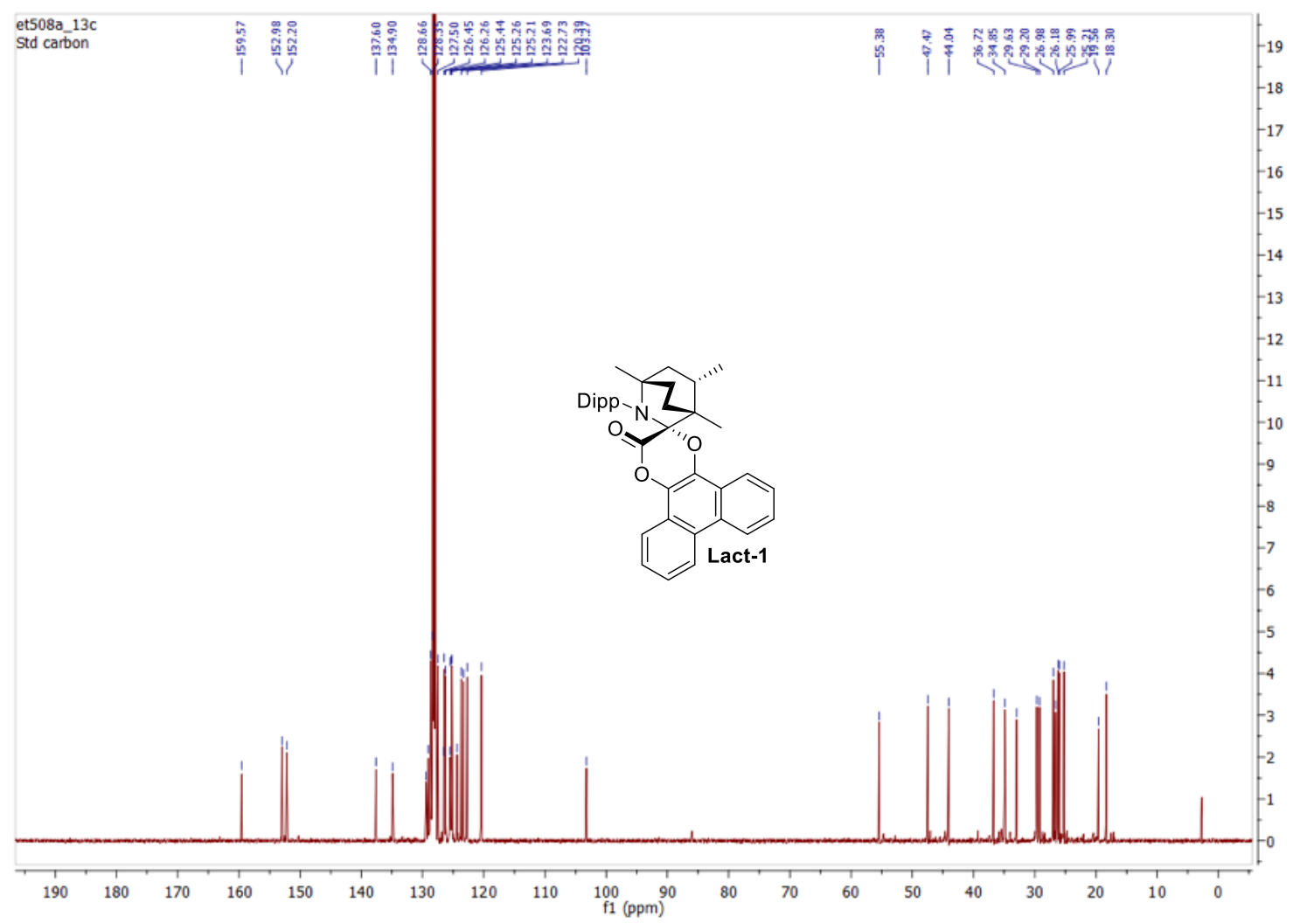

Fig. S33. ${ }^{13} \mathrm{C}\left\{{ }^{1} \mathrm{H}\right\}$ NMR (125.7 MHz, $\left.\mathrm{C}_{6} \mathrm{D}_{6}\right)$ of Lact-1. 


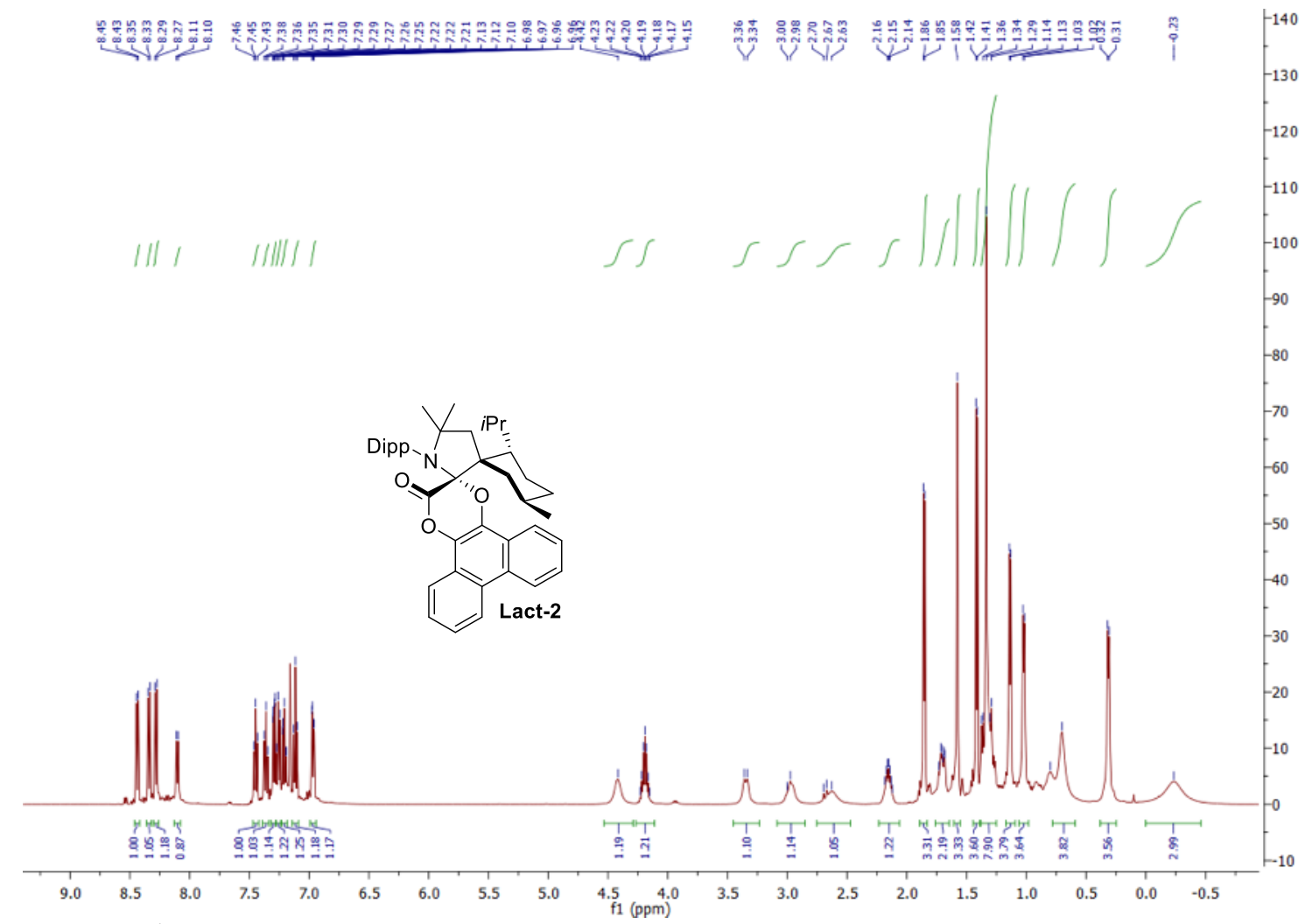

Fig. S34. ${ }^{1} \mathrm{H}$ NMR $\left(500 \mathrm{MHz}, \mathrm{C}_{6} \mathrm{D}_{6}\right)$ of Lact-2.

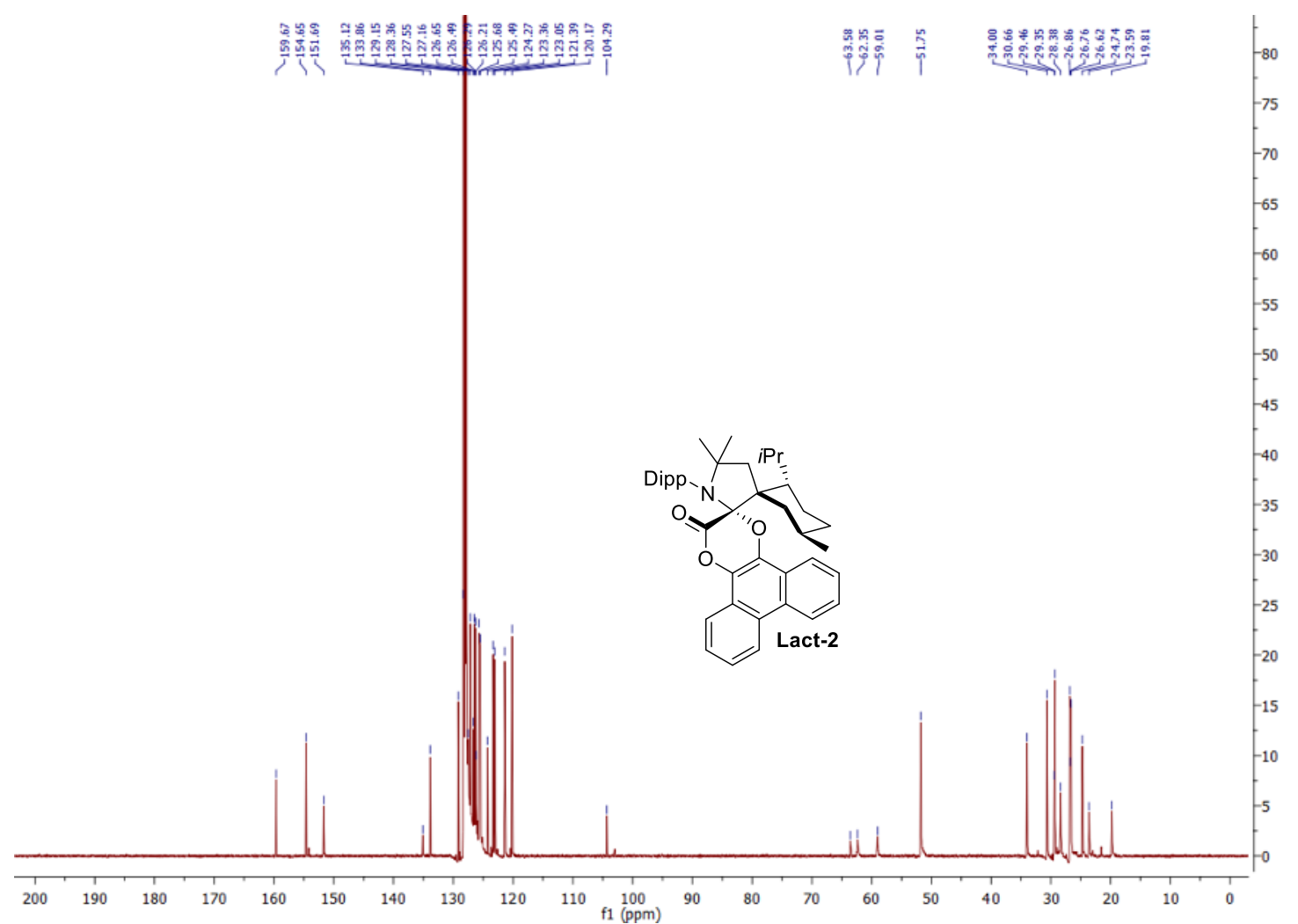

Fig. S35. ${ }^{13} \mathrm{C}\left\{{ }^{1} \mathrm{H}\right\}$ NMR (125.7 MHz, $\left.\mathrm{C}_{6} \mathrm{D}_{6}\right)$ of Lact-2. 


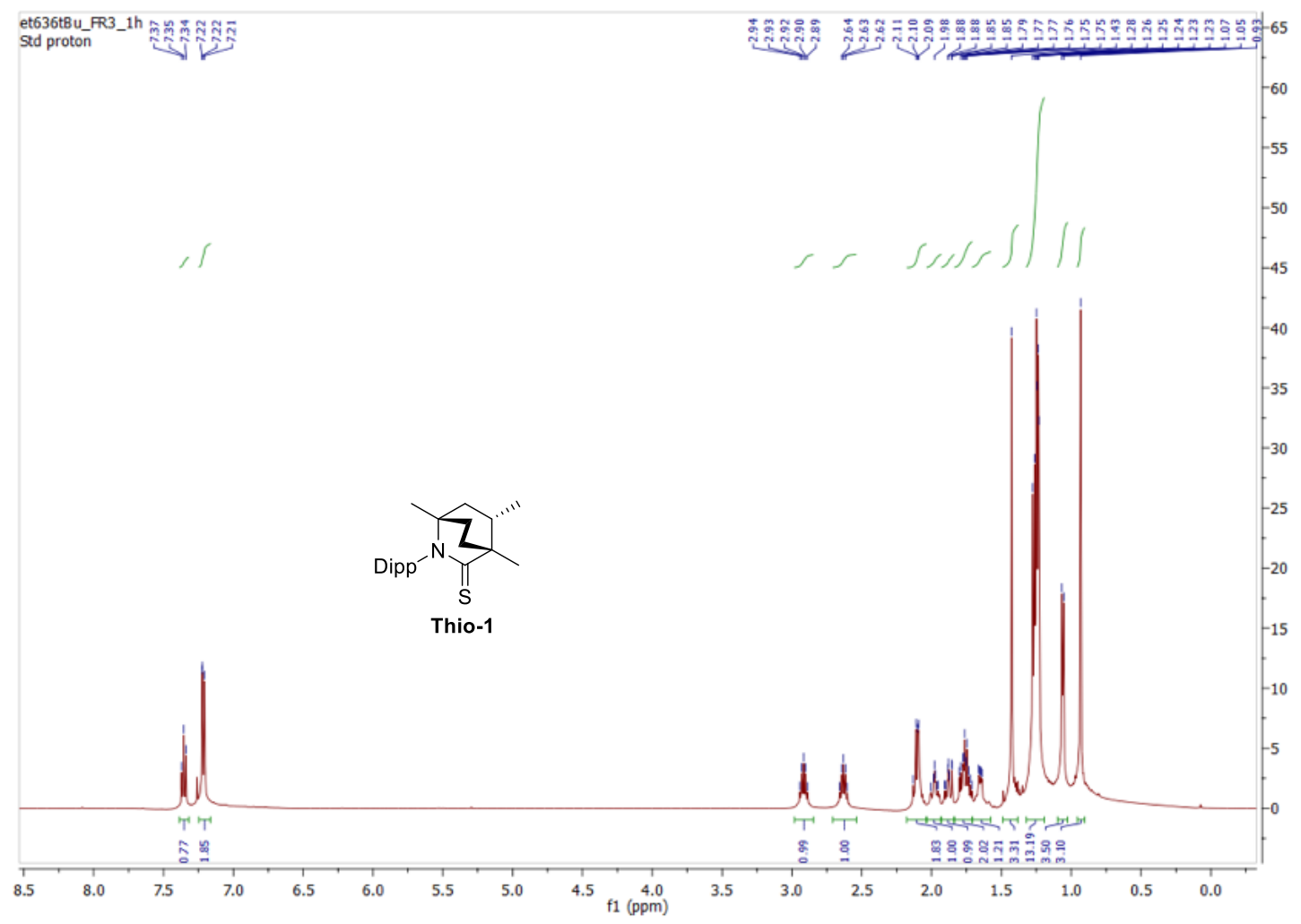

Fig. S36. ${ }^{1} \mathrm{H}$ NMR $\left(500 \mathrm{MHz}, \mathrm{CDCl}_{3}\right)$ of Thio-1.

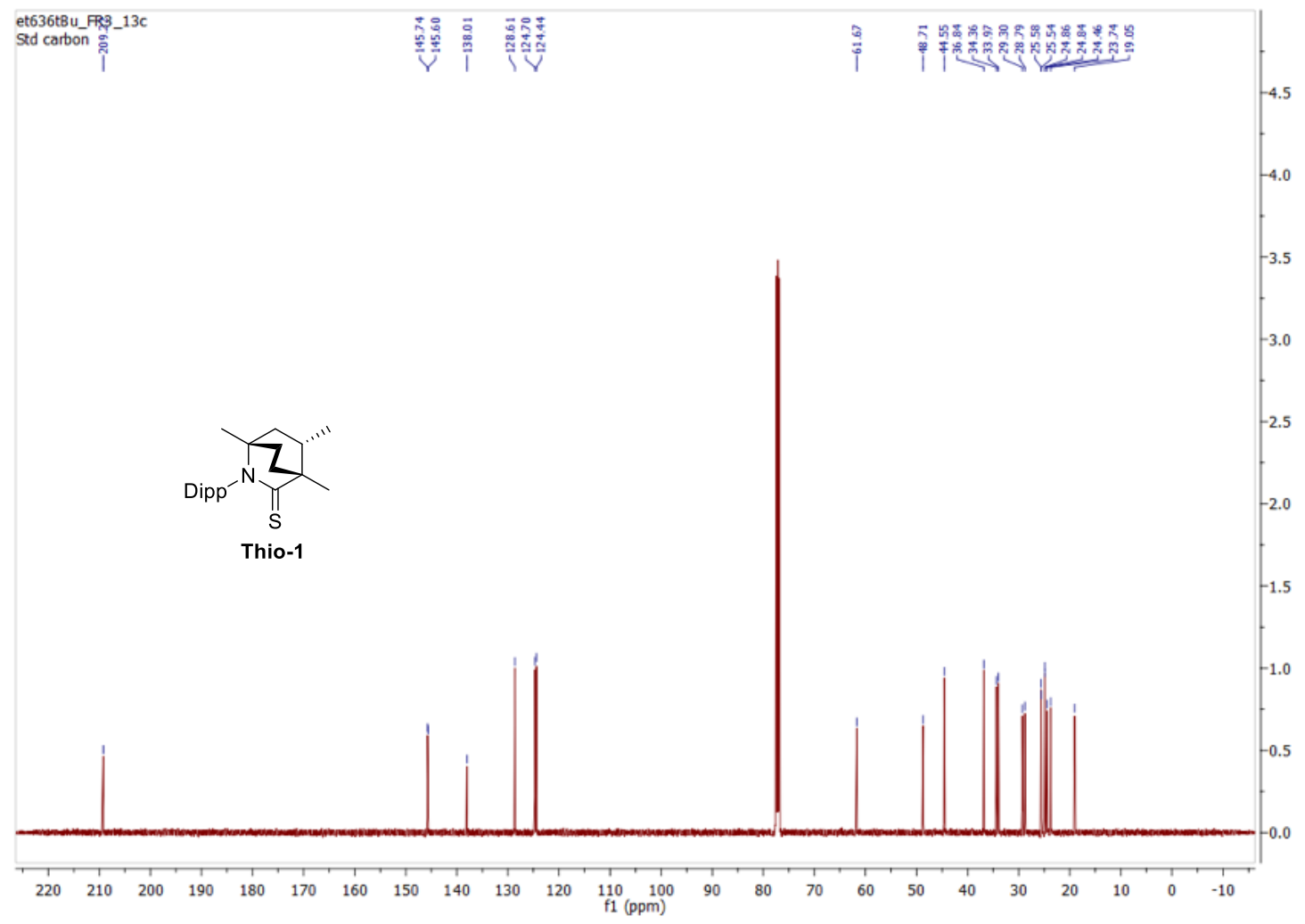

Fig. S37. ${ }^{13} \mathrm{C}\left\{{ }^{1} \mathrm{H}\right\}$ NMR (125.7 MHz, $\left.\mathrm{CDCl}_{3}\right)$ of Thio-1. 


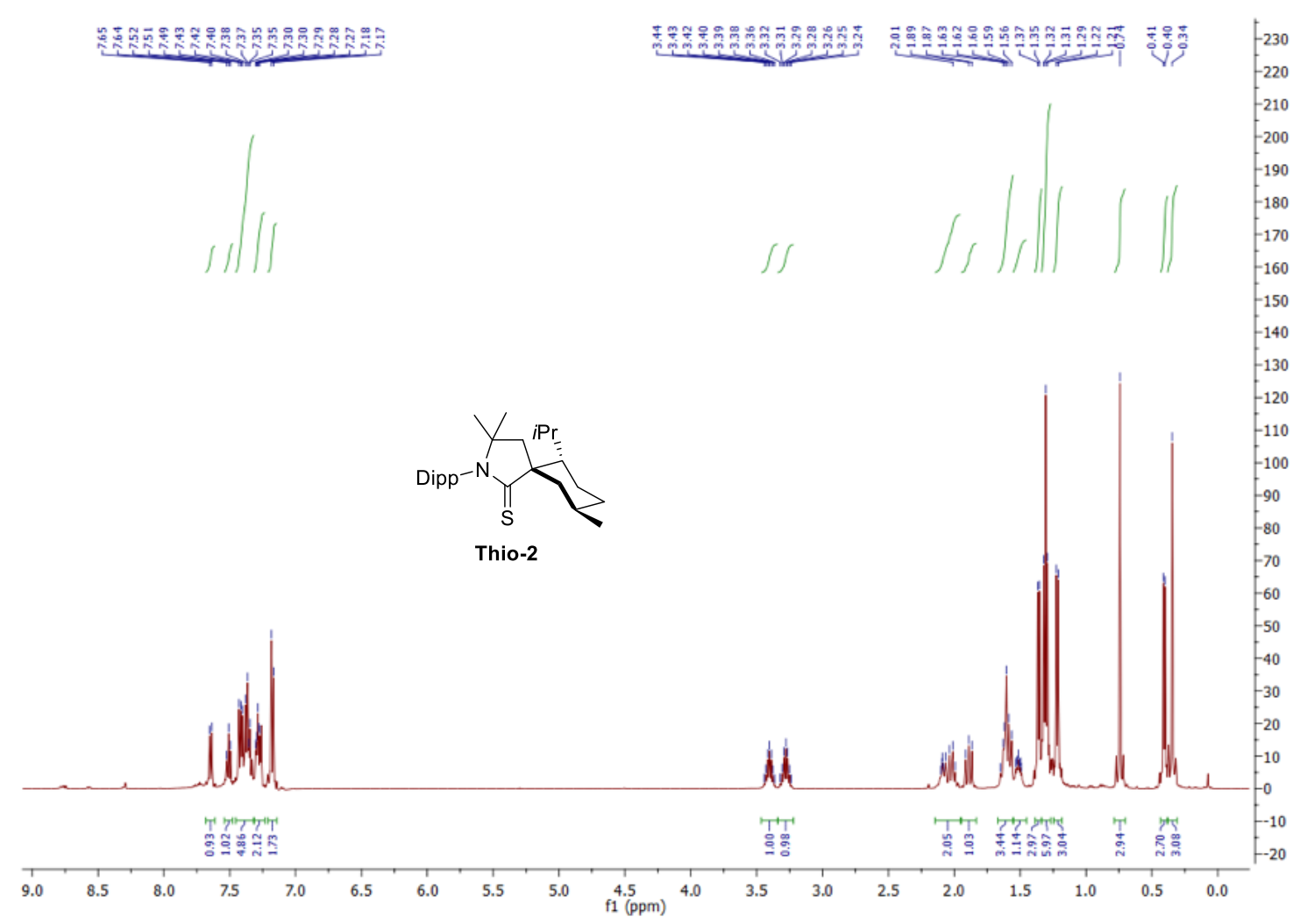

Fig. S38. ${ }^{1} \mathrm{H}$ NMR (500 MHz, THF-d8) of Thio-2.

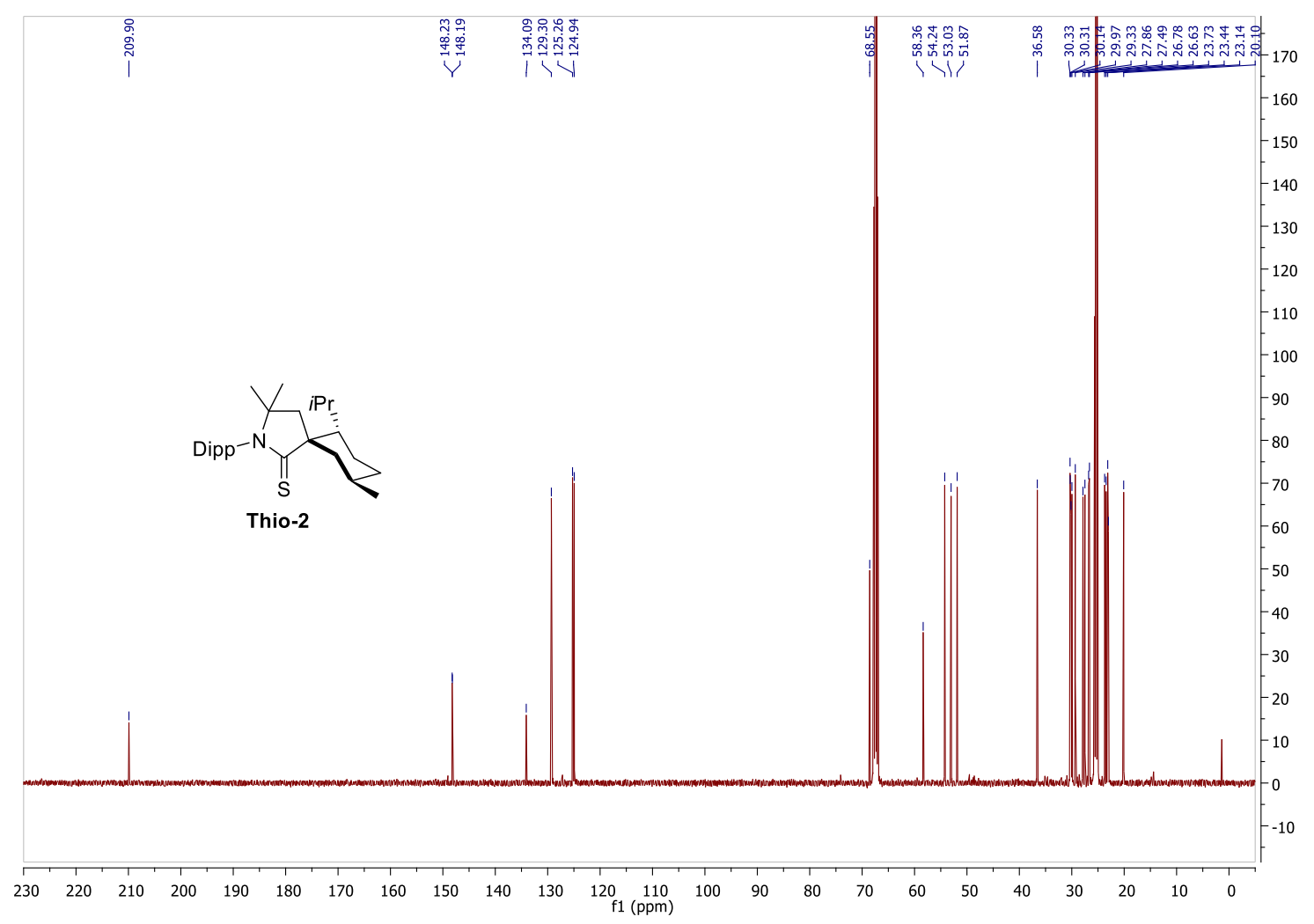

Fig. S39. ${ }^{13} \mathrm{C}\left\{{ }^{1} \mathrm{H}\right\} \mathrm{NMR}\left(125.7 \mathrm{MHz}, \mathrm{THF}-\mathrm{d}_{8}\right)$ of Thio-2. 


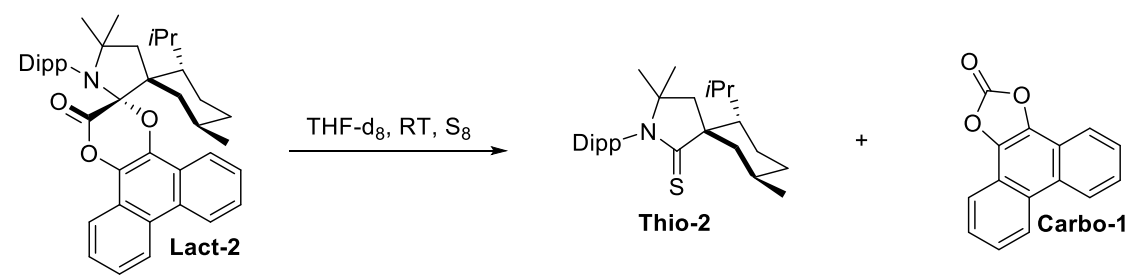

Fig. S40. Enforcing reductive elimination from Lact-2 in the presence of $S_{8}$ after 16 hours at room temperature (see below for spectrum, Fig. S41. A.).

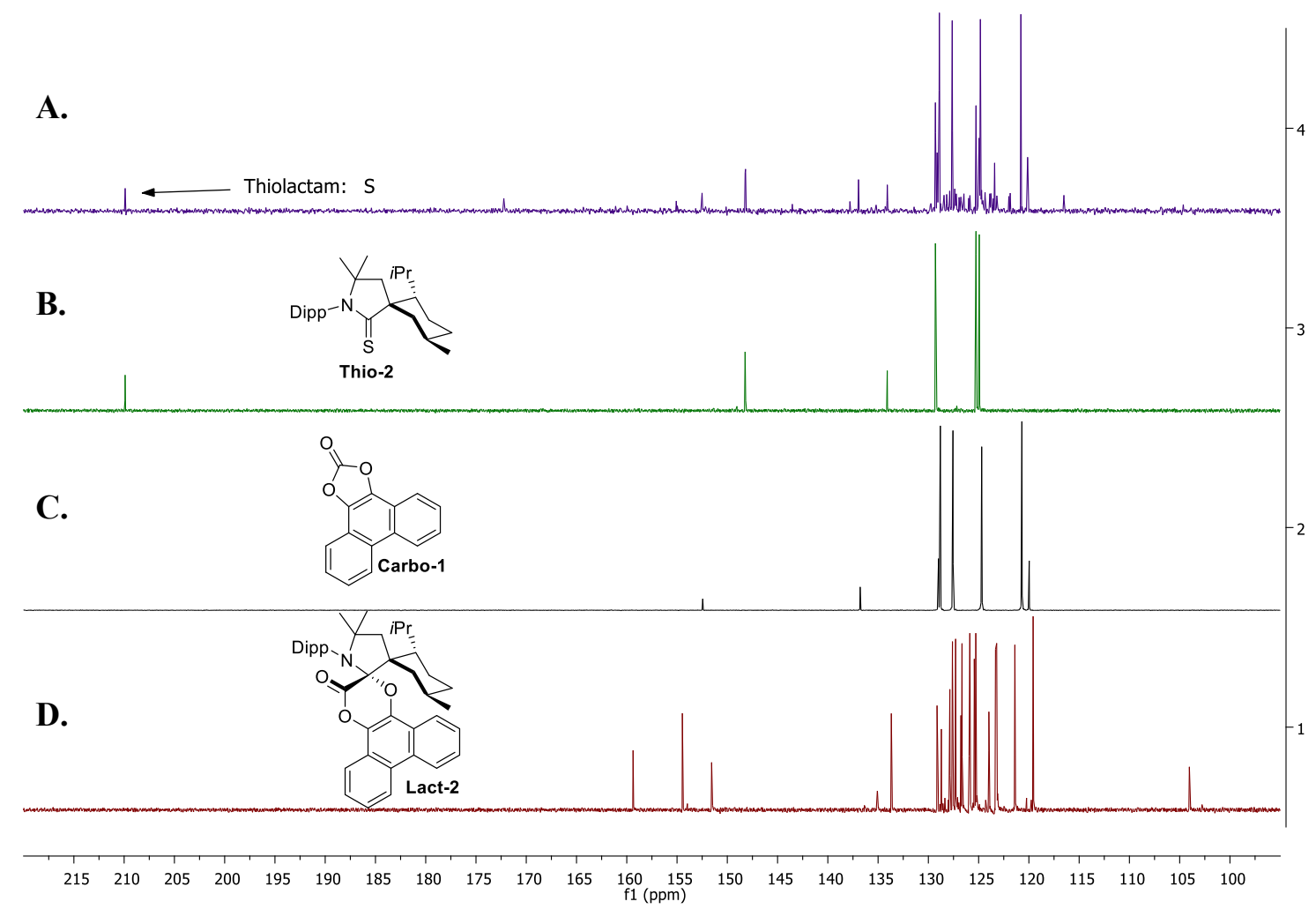

Fig. S41. Stacked ${ }^{13} \mathrm{C}\left\{{ }^{1} \mathrm{H}\right\}$ NMR $\left(125.7 \mathrm{MHz}\right.$, THF-d $\left.\mathrm{d}_{8}\right)$ spectra showing room temperature reductive elimination from Lact-2 by trapping the carbene as Thio-2; A. In situ reaction mixture of Lact-2 with elemental sulfur at room temperature after 16 hours (characteristic CS signal at 209.9 ppm) (see above for reaction, Fig. S40); B. Isolated Thio-2; C. Isolated Carbo-1; D. Isolated Lact-2. 


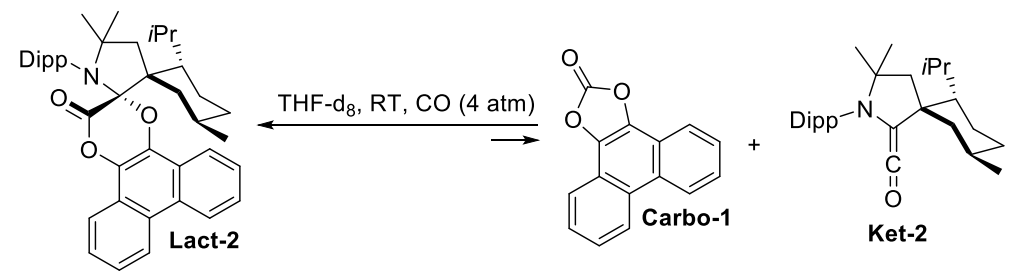

Fig. S42. Reductive elimination from Lact-2 in the presence of $\mathrm{CO}_{(\mathrm{g})}(4 \mathrm{~atm})$ after 48 hours at room temperature (see below for spectrum, Fig. S43. A).

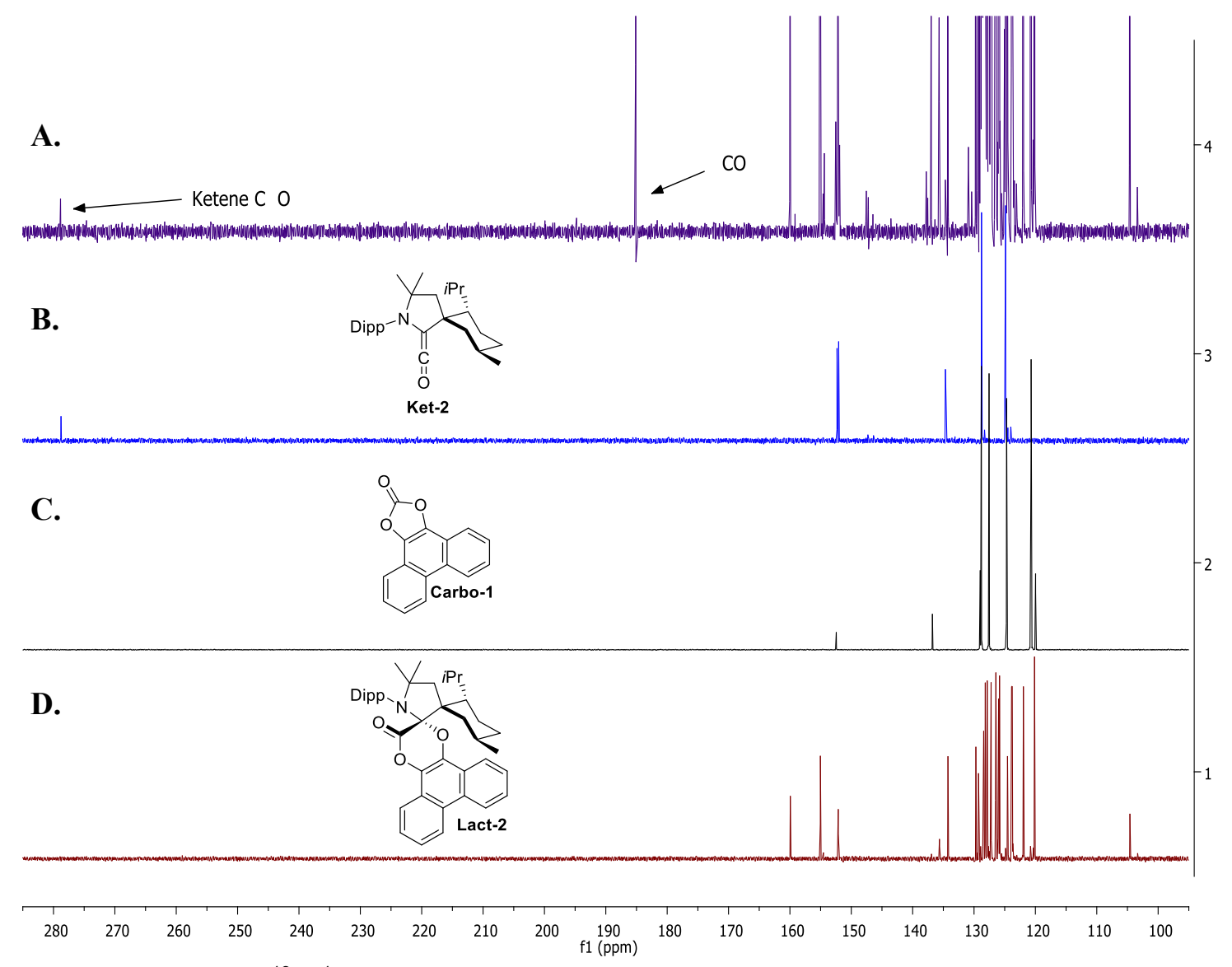

Fig. S43. Stacked ${ }^{13} \mathrm{C}\left\{{ }^{1} \mathrm{H}\right\}$ NMR $(125.7 \mathrm{MHz}$, THF-d 8 ) spectra showing room temperature reductive elimination from Lact-2; A. In situ reaction mixture of Lact-2 with $\mathrm{CO}_{(\mathrm{g})}(4 \mathrm{~atm})$ at room temperature after 48 hours (characteristic amino ketene CCO signal at $278.8 \mathrm{ppm}$ ) (see above for reaction, Fig. S42); B. Isolated Ket-2; C. Isolated Carbo-1; D. Isolated Lact-2. 


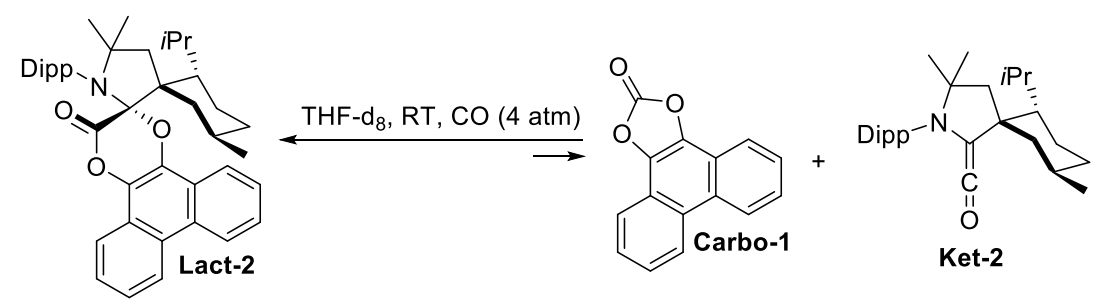

Fig. S44. Tracking reductive elimination from Lact-2 in the presence of $\mathrm{CO}_{(\mathrm{g})}$ over the course of 95 hours (see below for spectra, Fig. S45. A).

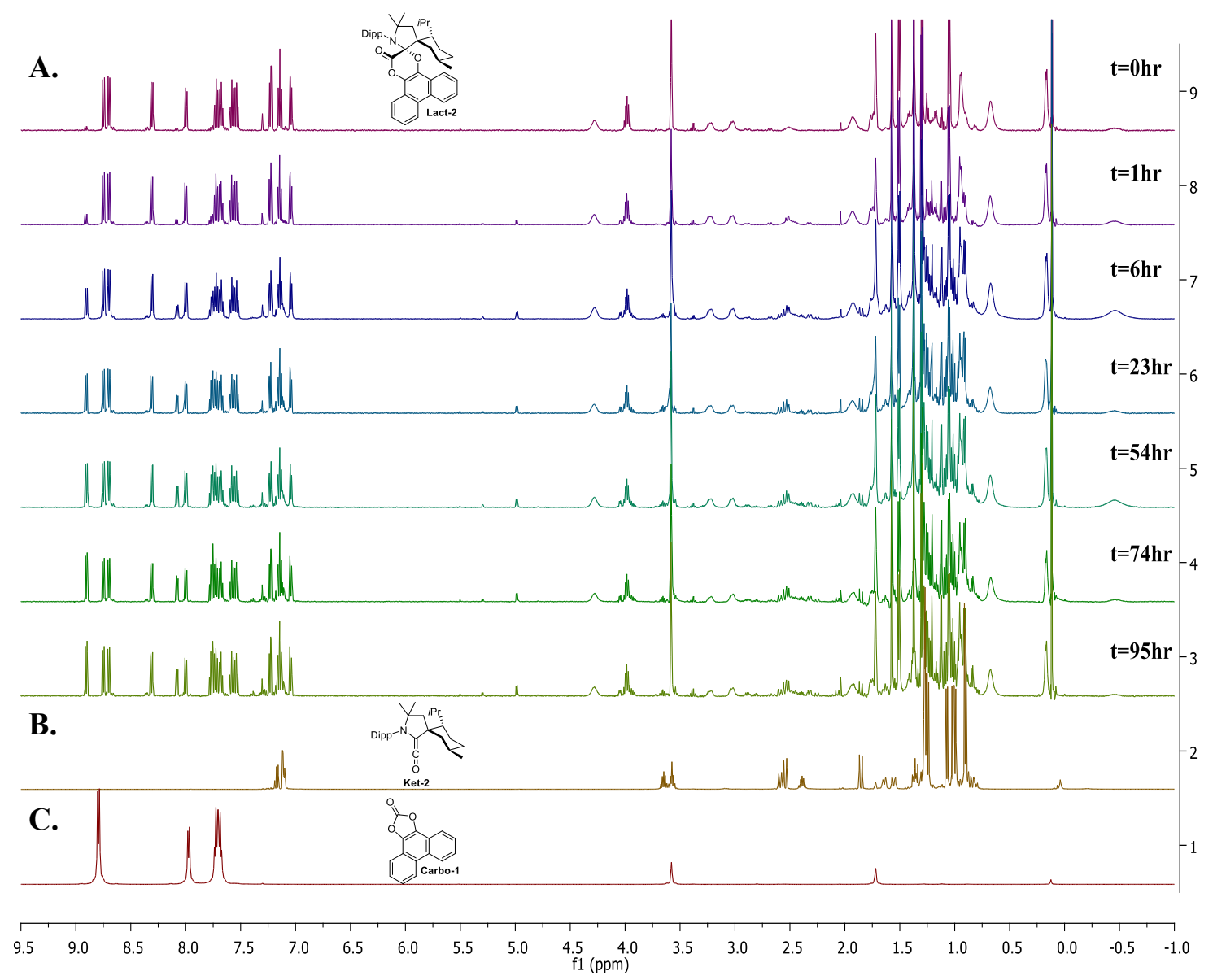

Fig. S45. Stacked ${ }^{1} \mathrm{H}$ NMR $\left(500 \mathrm{MHz}, \mathrm{THF}-\mathrm{d}_{8}\right)$ spectra tracking the room temperature reductive elimination from Lact-2 over the course of 95 hours; A. In situ reaction mixture of Lact-2 with $\mathrm{CO}_{(\mathrm{g})}(4 \mathrm{~atm})$ at room temperature with several spectra ranging in time $(\mathrm{t})$ from 0-95 hours from top to bottom (see above for reaction, Fig. S44); B. Isolated Ket-2; C. Isolated Carbo-1. 


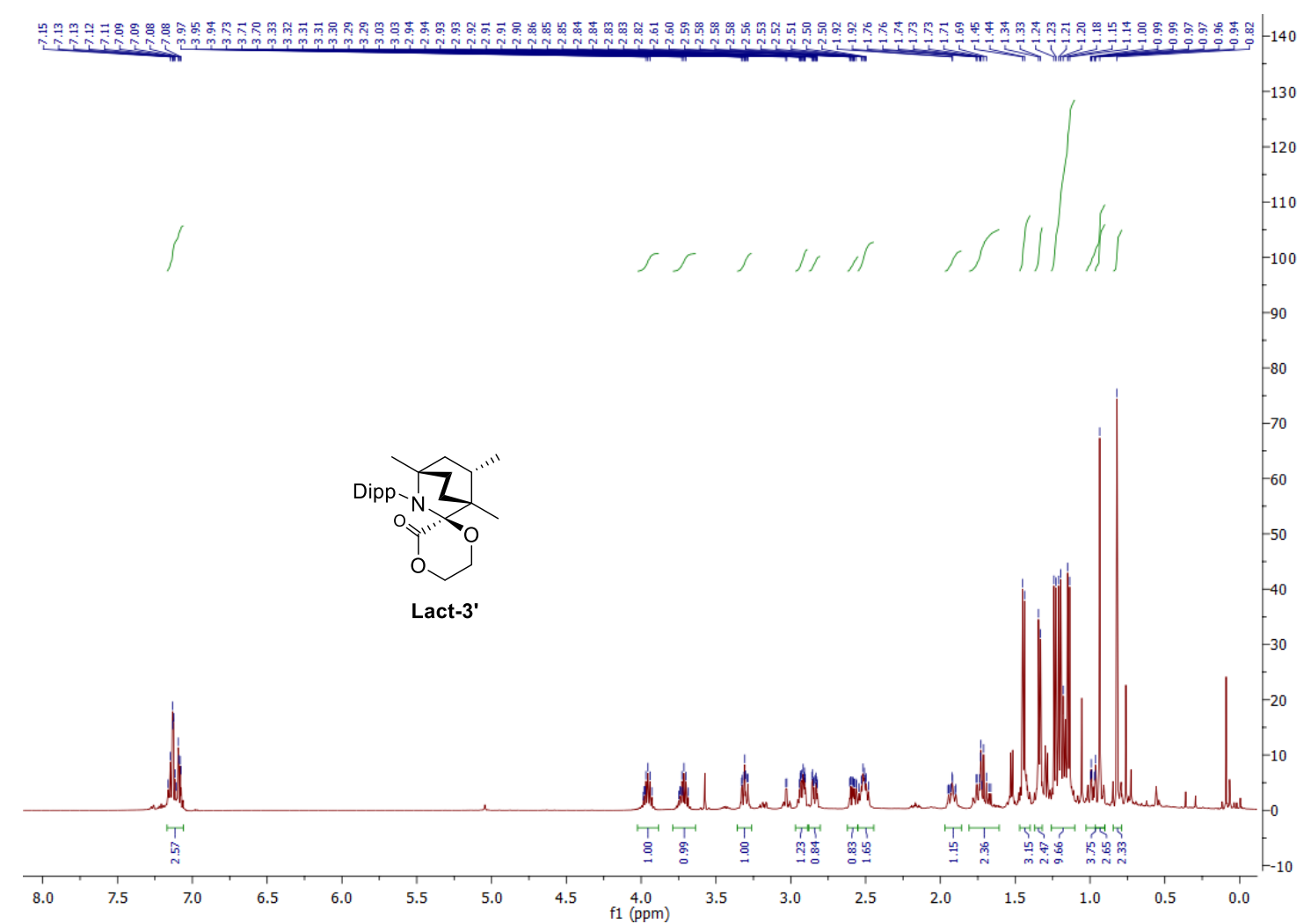

Fig. S46. ' $\mathrm{H}$ NMR $\left(500 \mathrm{MHz}, \mathrm{C}_{6} \mathrm{D}_{6}\right)$ of Lact-3'.

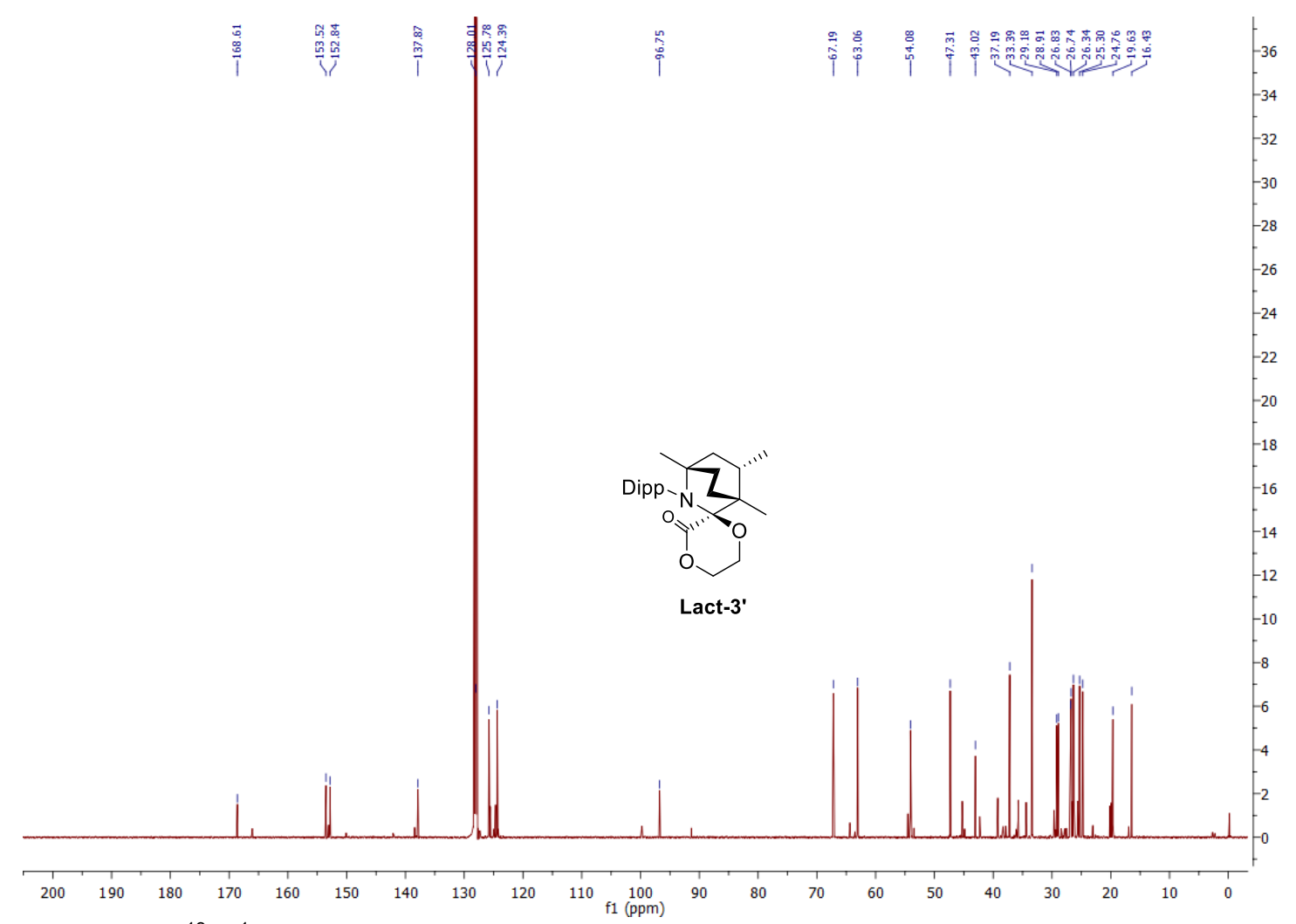

Fig. S47. ${ }^{13} \mathrm{C}\left\{{ }^{1} \mathrm{H}\right\}$ NMR $\left(125.7 \mathrm{MHz}, \mathrm{C}_{6} \mathrm{D}_{6}\right)$ of Lact-3' (weak signals belong to the thermodynamic isomer Lact-3). 


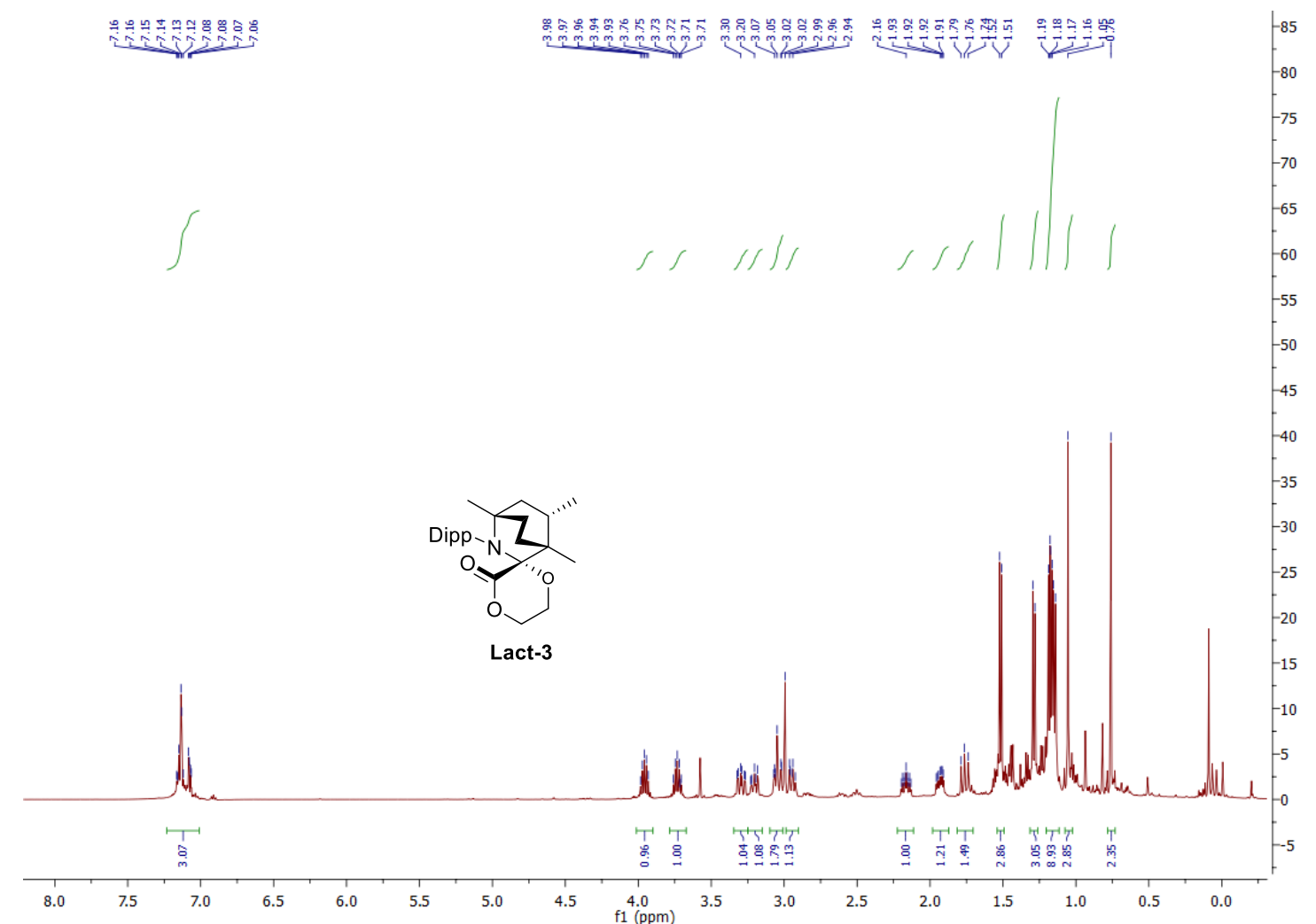

Fig. S48. ${ }^{1} \mathrm{H}$ NMR $\left(500 \mathrm{MHz}, \mathrm{C}_{6} \mathrm{D}_{6}\right)$ of Lact-3.

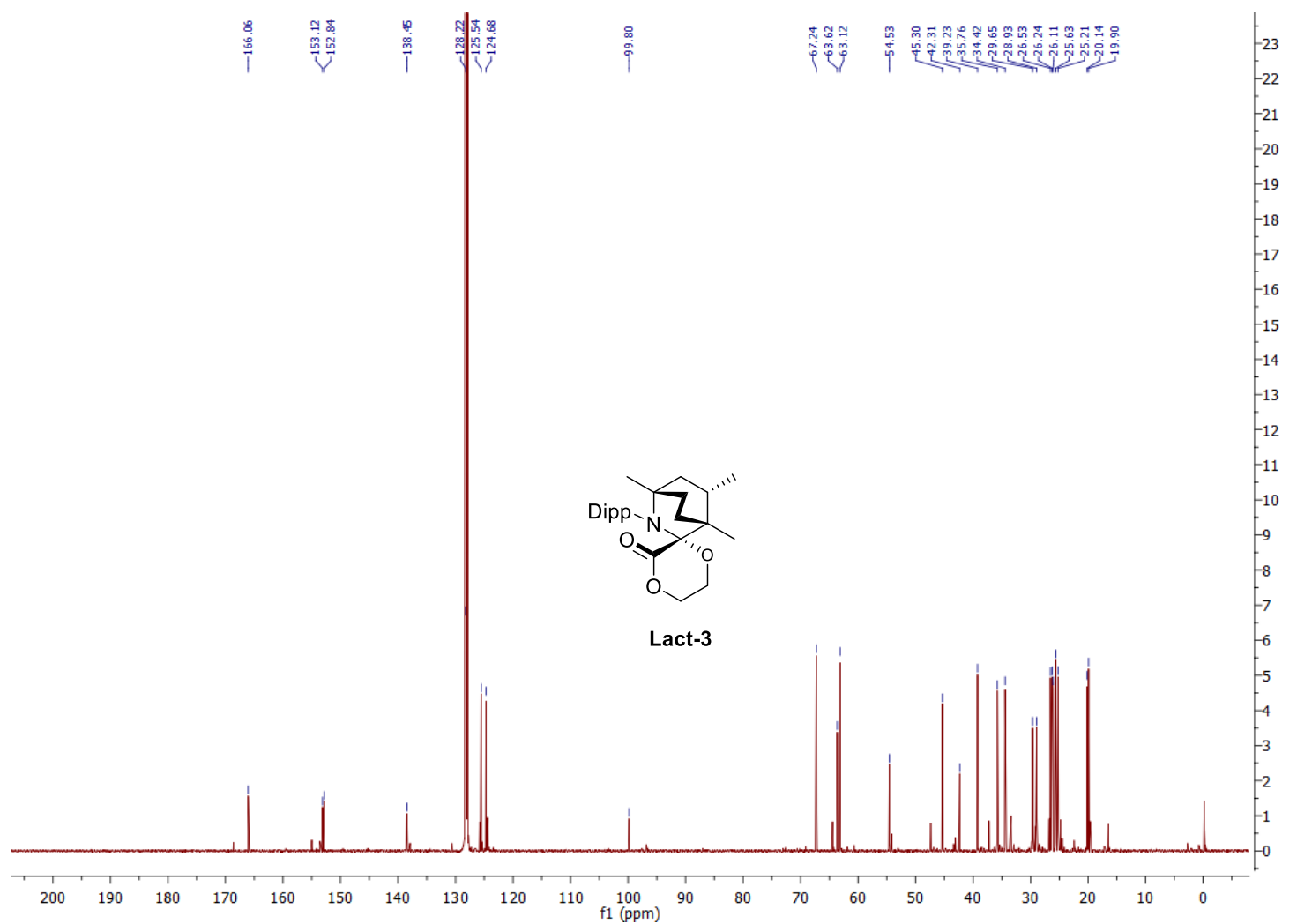

Fig. S49. ${ }^{13} \mathrm{C}\left\{{ }^{1} \mathrm{H}\right\}$ NMR $\left(125.7 \mathrm{MHz}, \mathrm{C}_{6} \mathrm{D}_{6}\right)$ of Lact-3 (weak signals belong to the kinetic isomer Lact-3'). 


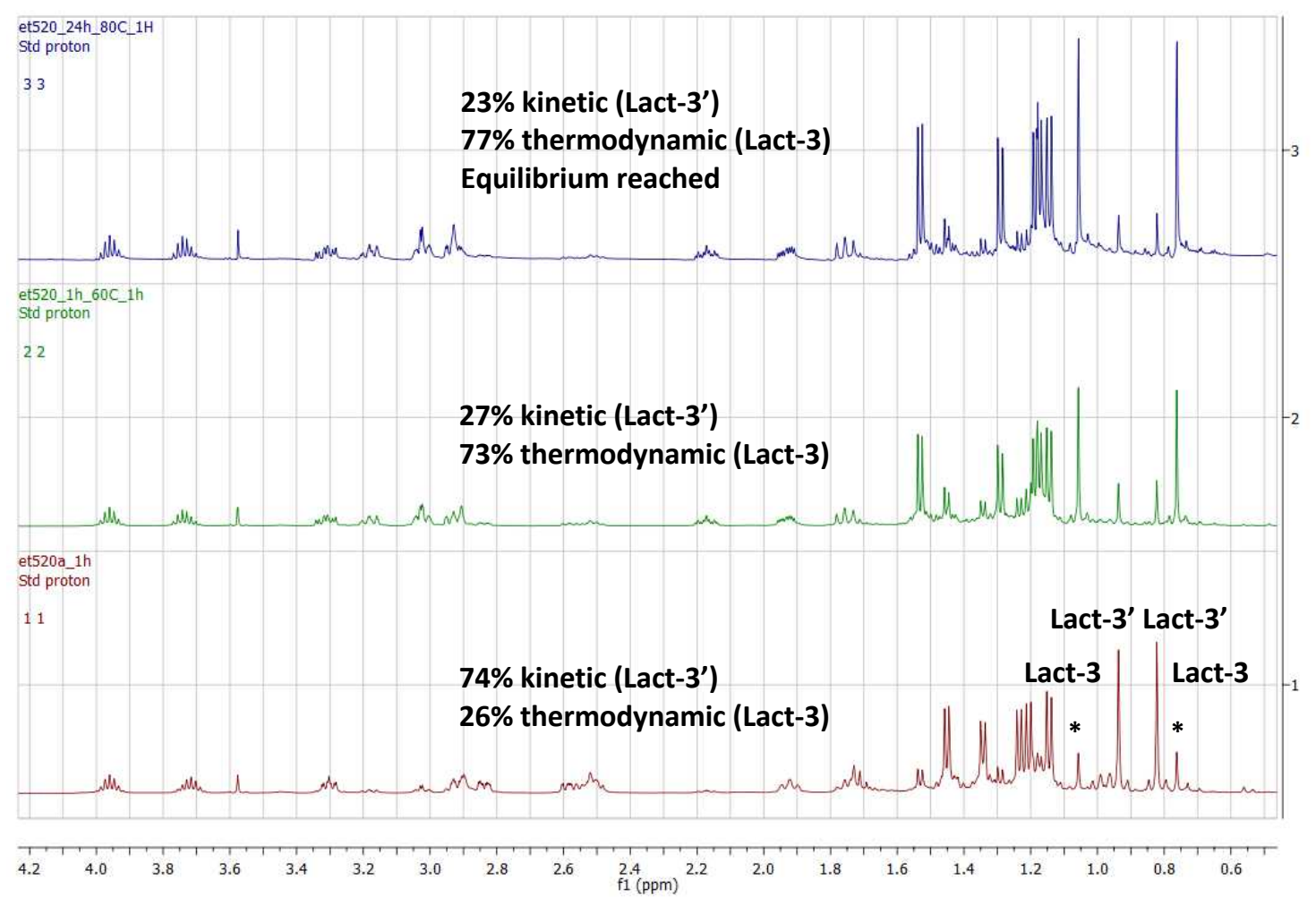

Fig. S50. Stacked ${ }^{1} \mathrm{H}$ NMR $\left(\mathrm{C}_{6} \mathrm{D}_{6}, 500 \mathrm{MHz}\right)$ showing the isomerization between Lact-3 and Lact-3' using an external hot bath: (1) to at room temperature; (2) $\mathrm{t}_{1}=1$ hour at $60{ }^{\circ} \mathrm{C}$; (3) $\mathrm{t}_{2}=$ 24 hours at $80^{\circ} \mathrm{C}$.

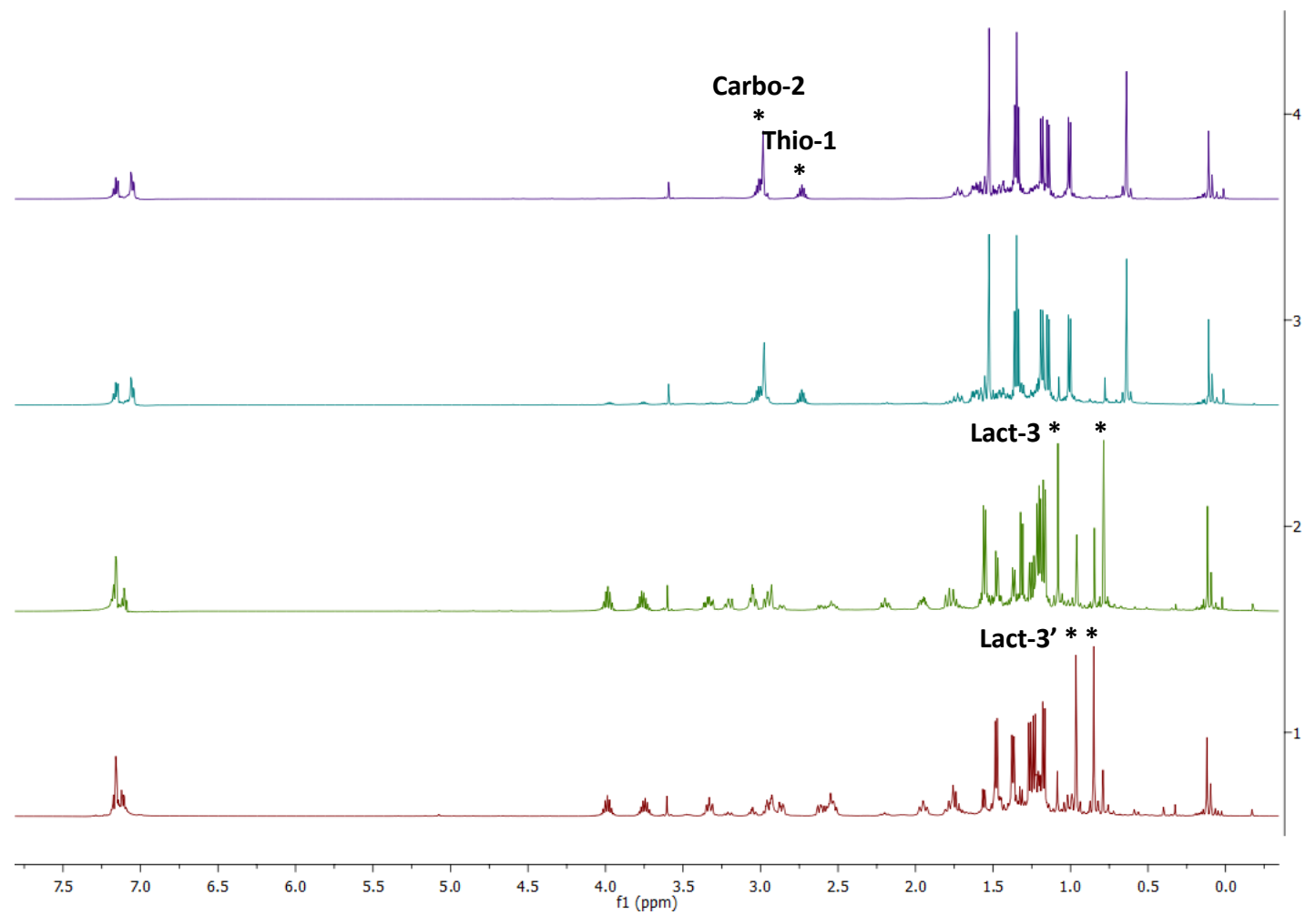

Fig. S51. Stacked ${ }^{1} \mathrm{H}$ NMR $\left(\mathrm{C}_{6} \mathrm{D}_{6}, 500 \mathrm{MHz}\right)$ showing the isomerization between diastereoisomers, Lact-3 (minor) and Lact-3' (major), and then the trapping of the free carbene with elemental sulfur: (1) to at $20^{\circ} \mathrm{C}$ shows the initially formed Lact-3'; (2) $\mathrm{t}_{1}=1$ hour at $60{ }^{\circ} \mathrm{C}$ shows the thermodynamic product Lact-3; (3) after elemental sulfur added and then allowed to react for 4 hours at $80^{\circ} \mathrm{C}$; (4) 24 hours at $80^{\circ} \mathrm{C}$ led to the clean formation of Thio-1. 


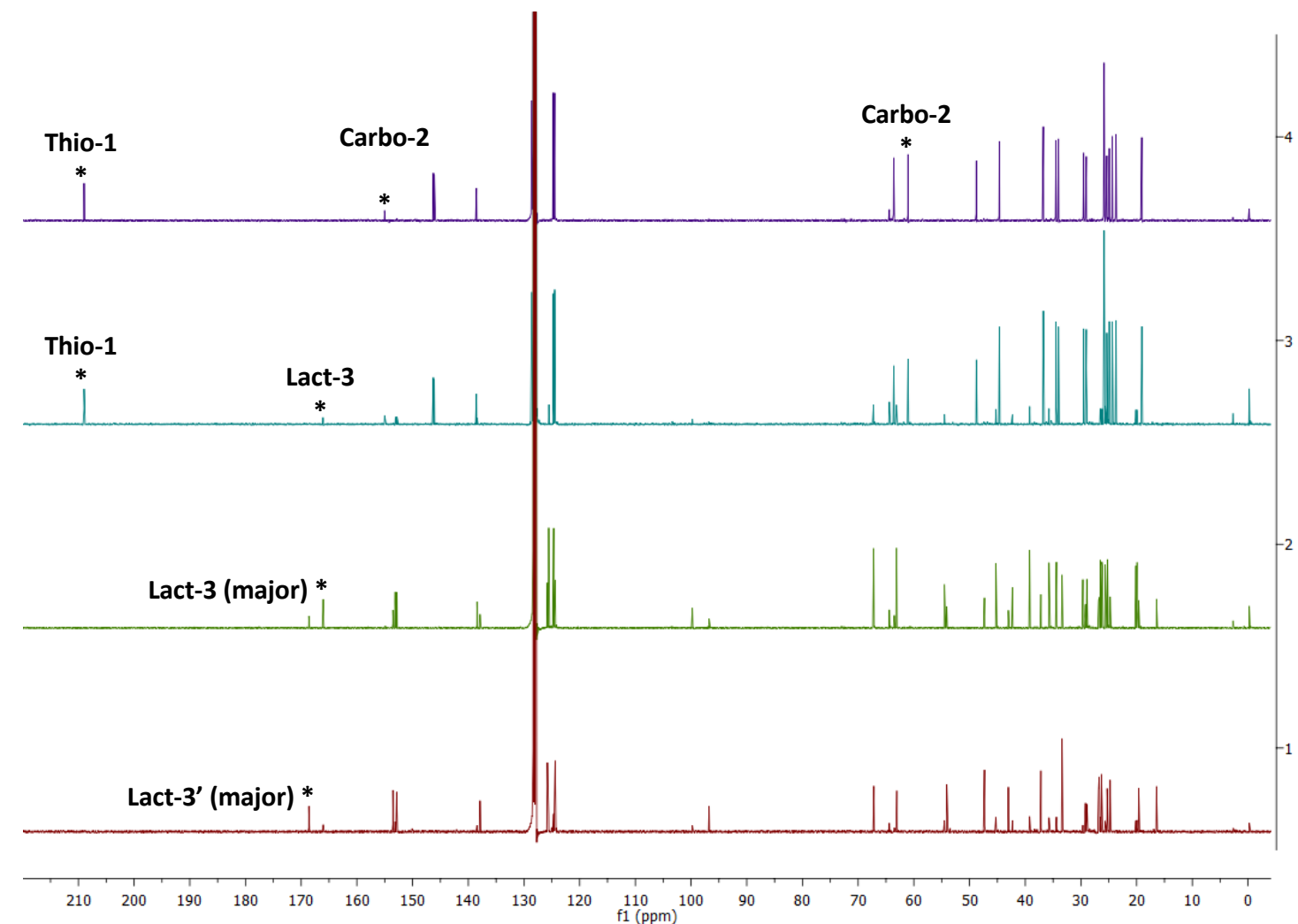

Fig. S52. Stacked ${ }^{13} \mathrm{C}\left\{{ }^{1} \mathrm{H}\right\}$ NMR $\left(\mathrm{C}_{6} \mathrm{D}_{6}, 125.7 \mathrm{MHz}\right)$ following the isomerization between diastereoisomers, Lact-3 (minor) and Lact-3' (major), and then the trapping of the free carbene with elemental sulfur: (1) to at $20^{\circ} \mathrm{C}$ shows Lact-3'; (2) $\mathrm{t}_{1}=1$ hour at $60^{\circ} \mathrm{C}$ shows major Lact-3; (3) after elemental sulfur added and then allowed to react for 4 hours at $80{ }^{\circ} \mathrm{C}$; (4) 24 hours at $80^{\circ} \mathrm{C}$ leads to the clean formation of Thio-1. 


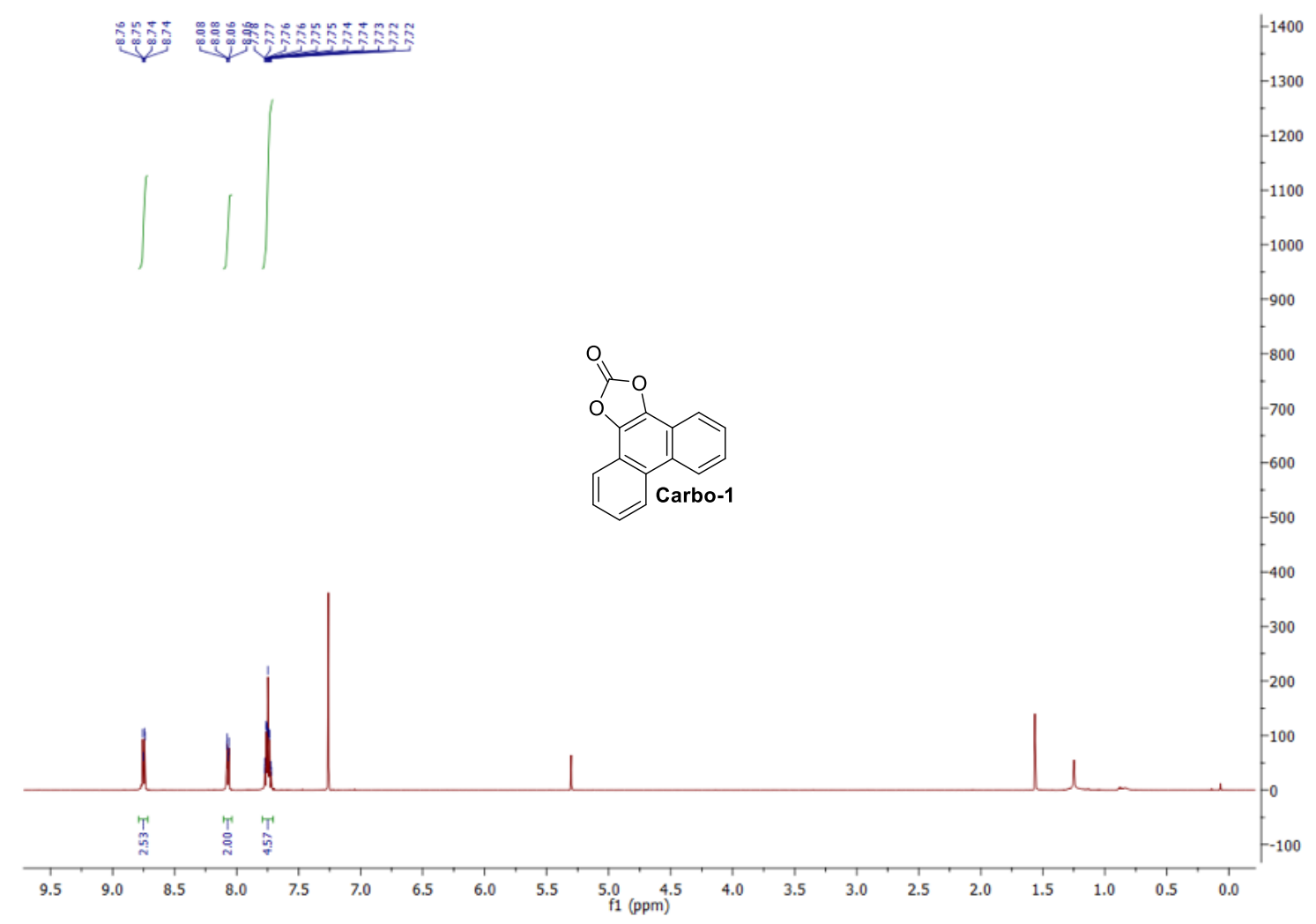

Fig. S53. ${ }^{1} \mathrm{H}$ NMR $\left(500 \mathrm{MHz}, \mathrm{CDCl}_{3}\right)$ of Carbo-1.

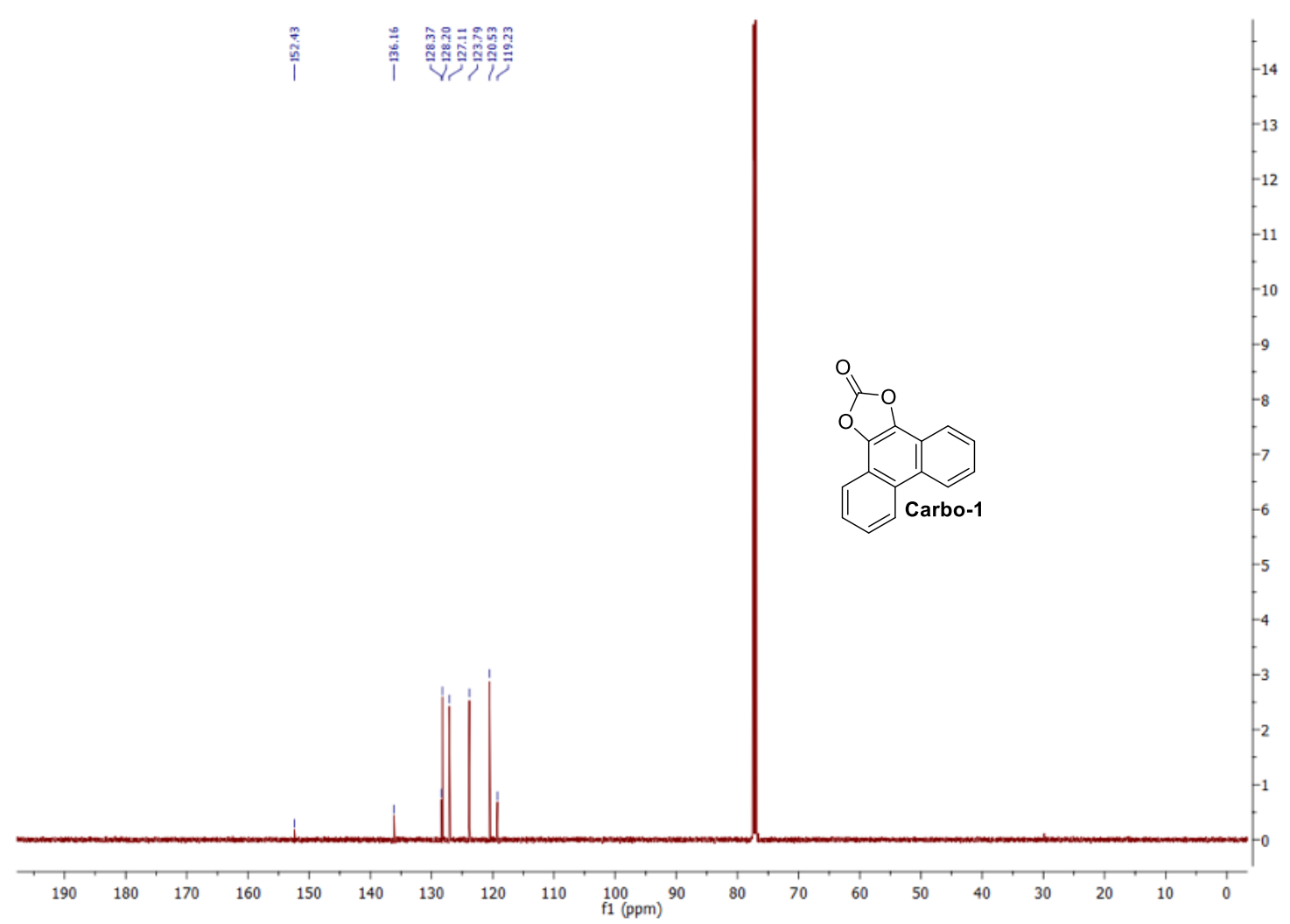

Fig. S54. ${ }^{13} \mathrm{C}\left\{{ }^{1} \mathrm{H}\right\} \mathrm{NMR}\left(125.7 \mathrm{MHz}, \mathrm{CDCl}_{3}\right)$ of Carbo-1. 


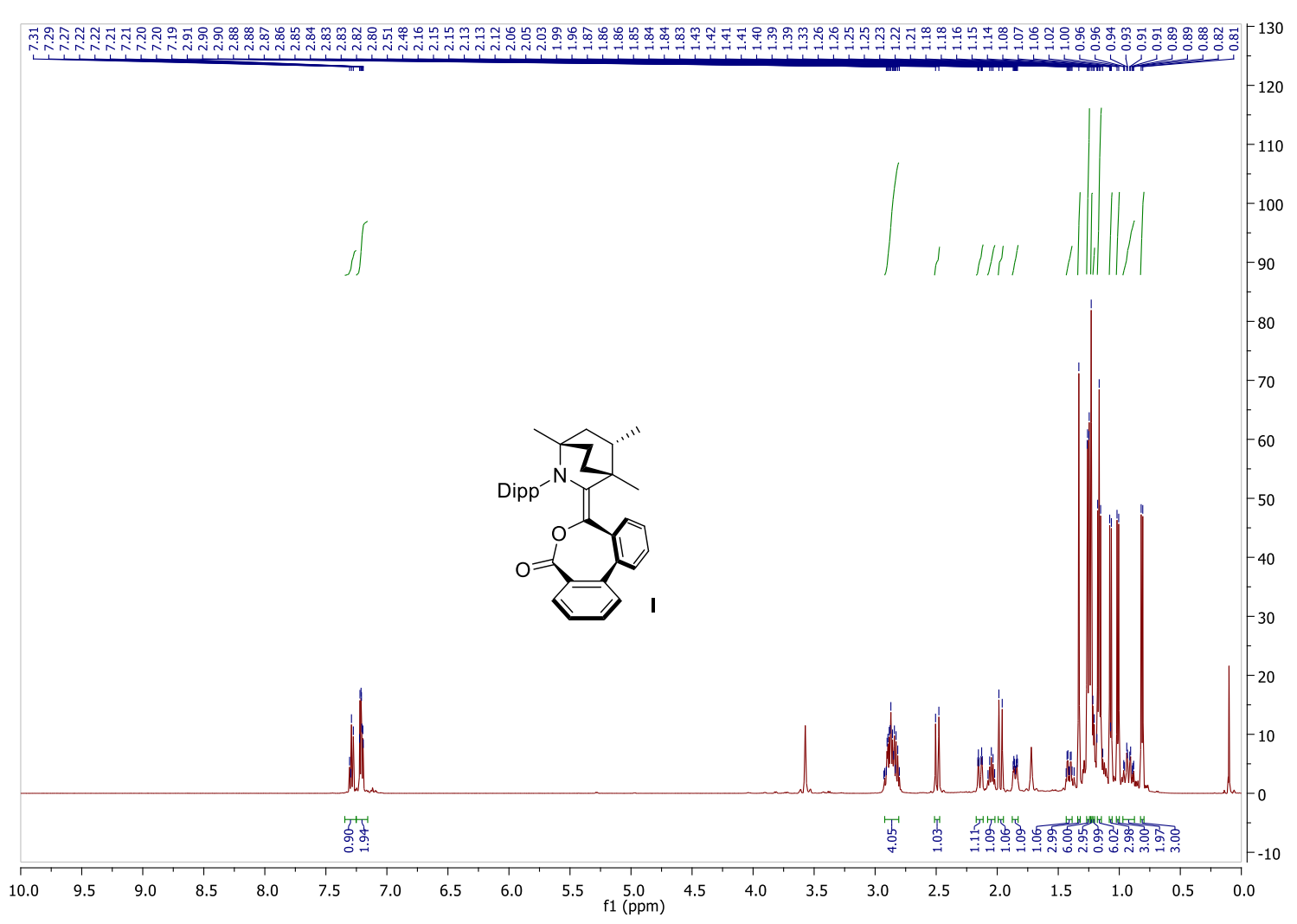

Fig. S55. ${ }^{1} \mathrm{H} \mathrm{NMR}\left(500 \mathrm{MHz}, \mathrm{CDCl}_{3}\right)$ of I.

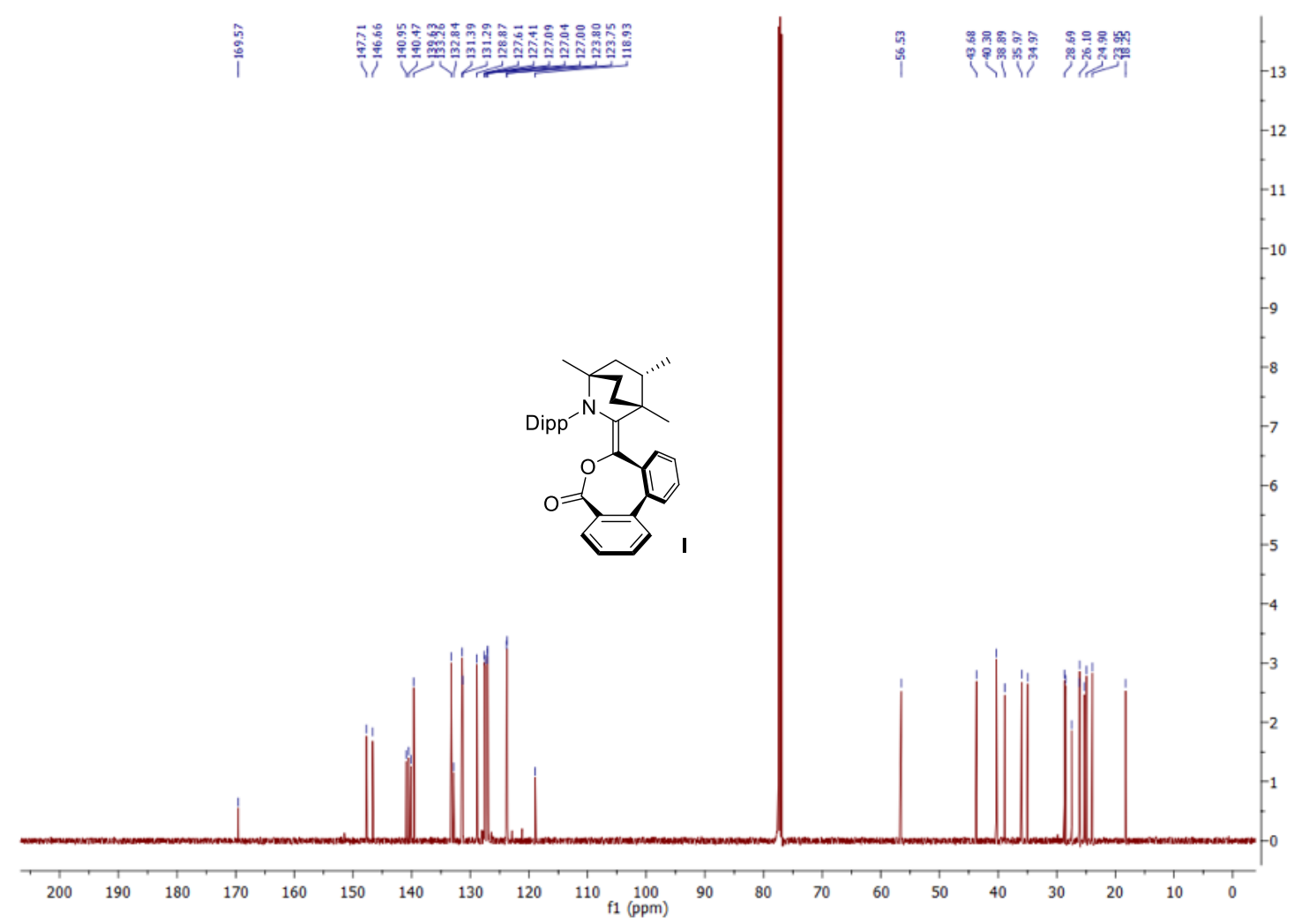

Fig. S56. ${ }^{13} \mathrm{C}\left\{{ }^{1} \mathrm{H}\right\}$ NMR $\left(125.7 \mathrm{MHz}, \mathrm{CDCl}_{3}\right)$ of I. 


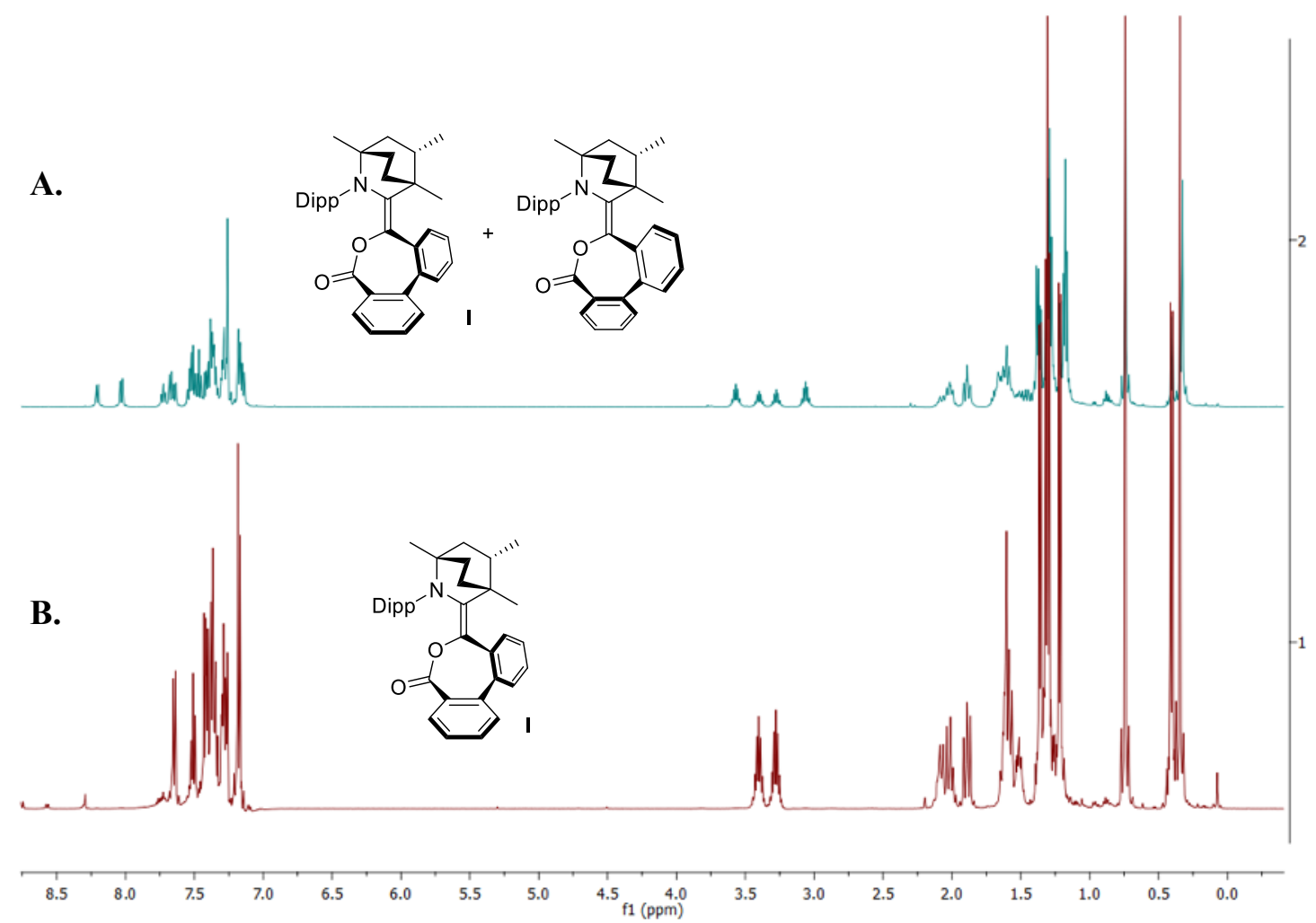

Fig. S57. Stacked ${ }^{1} \mathrm{H}$ NMR $\left(500 \mathrm{MHz}, \mathrm{CDCl}_{3}\right)$ spectra of $\mathrm{I}$ and its conformer; A. Before purification on silica gel showing a diastereomeric mixture of atropisomers; B. Showing one isomer I after silica gel column purification of the mixture in $\mathbf{A}$.

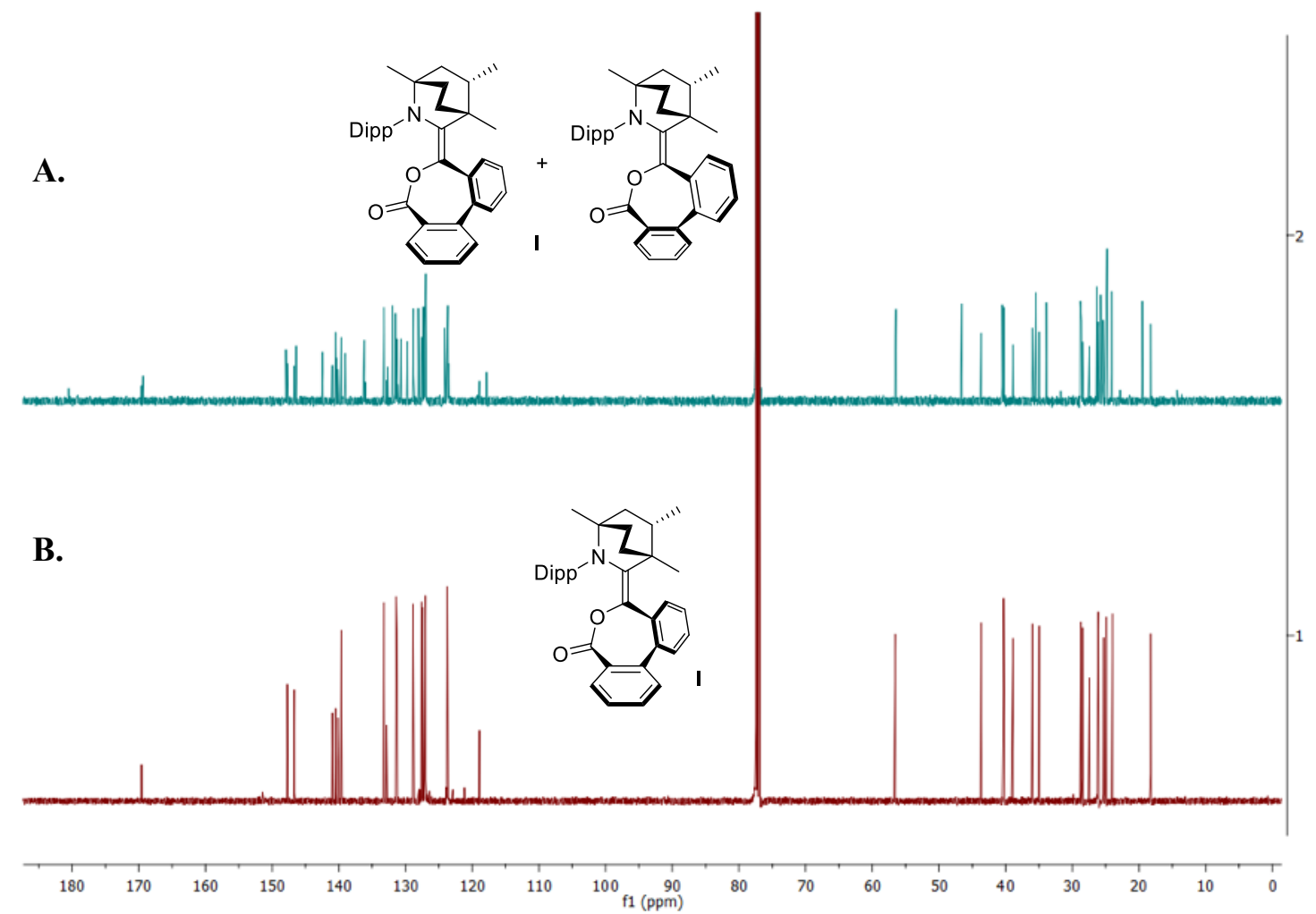

Fig. S58. Stacked ${ }^{13} \mathrm{C}\left\{{ }^{1} \mathrm{H}\right\}$ NMR $\left(125.7 \mathrm{MHz}, \mathrm{CDCl}_{3}\right)$ spectra of I and its conformer; A. Before purification on silica gel showing a diastereomeric mixture of atropisomers; B. Showing one isomer I after silica gel column purification of the mixture in $\mathbf{A}$. 


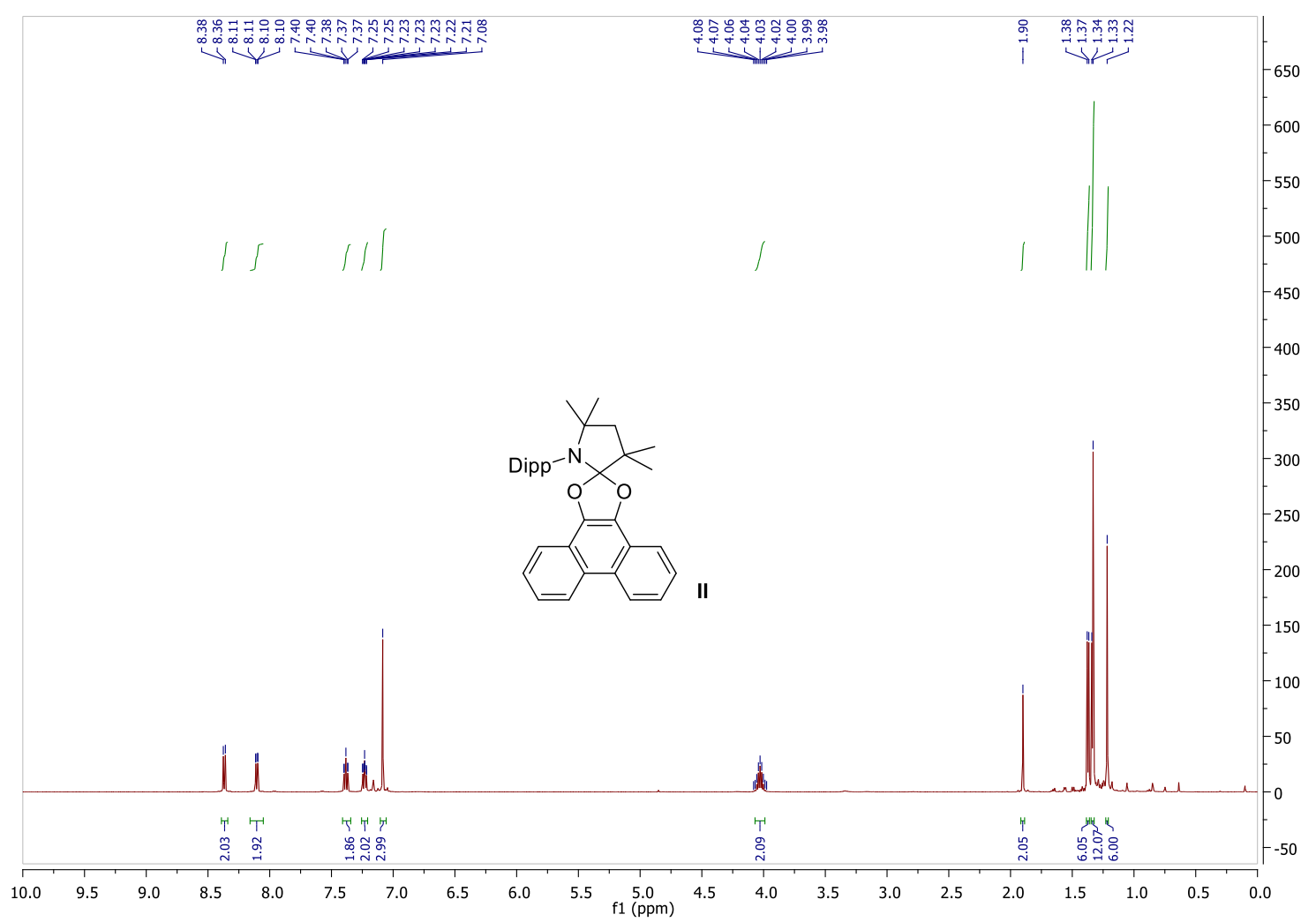

Fig. S59. ${ }^{1} \mathrm{H}$ NMR (500 MHz, $\left.\mathrm{C}_{6} \mathrm{D}_{6}\right)$ of II.

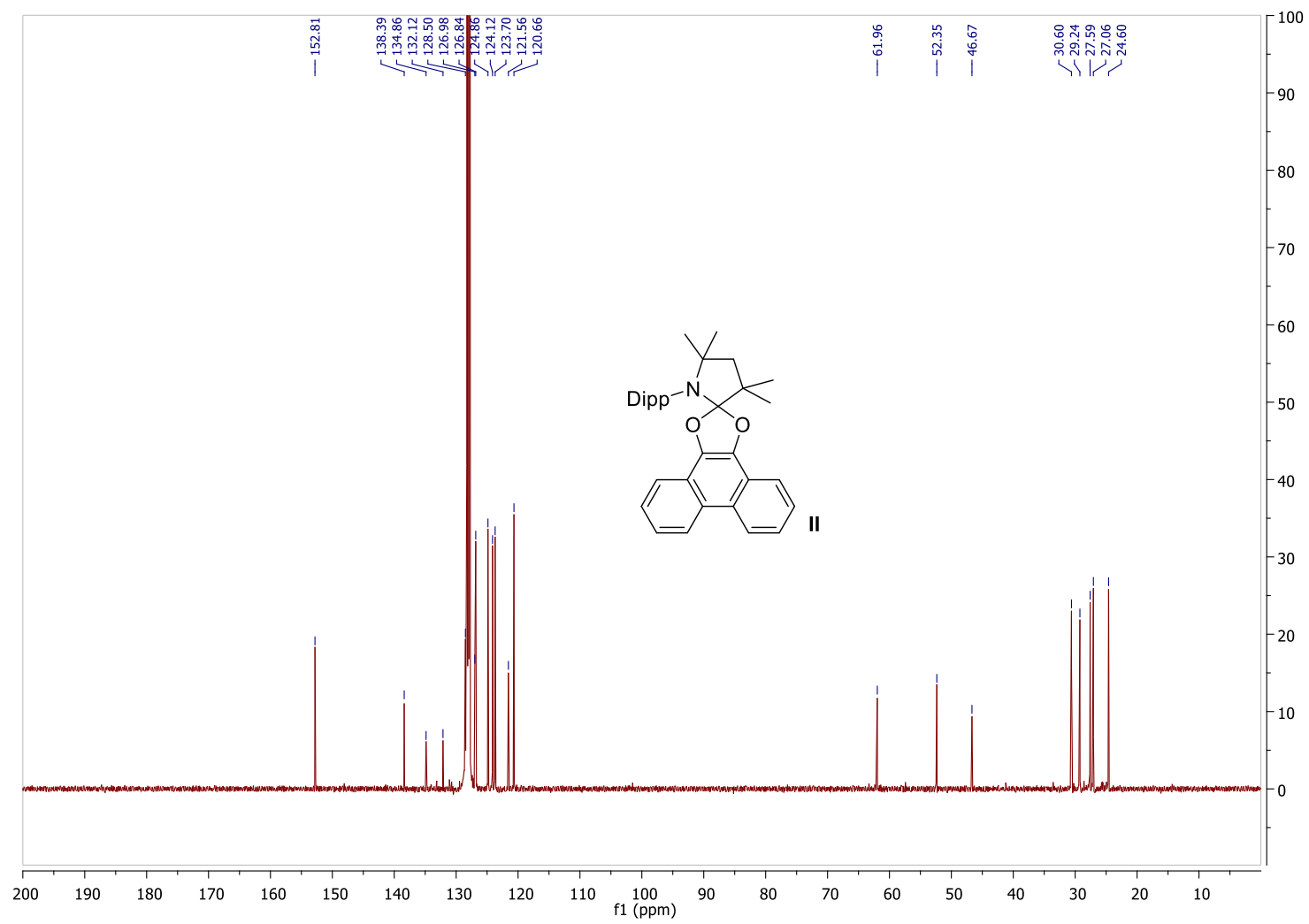

Fig. S60. ${ }^{13} \mathrm{C}\left\{{ }^{1} \mathrm{H}\right\}$ NMR $\left(125.7 \mathrm{MHz}, \mathrm{C}_{6} \mathrm{D}_{6}\right)$ of II. 
(1) Tomás-Mendivil, E.; Hansmann, M. M.; Weinstein; C. M., Jazzar, R.; Melaimi, M; Bertrand, G. Bicyclic (alkyl)(amino)carbenes (BICAACs): stable carbenes more ambiphilic than CAACs. J. Am. Chem. Soc. 2017, 139, 7753-7756.

(2) Jazzar, R.; Dewhurst, R. D., Bourg, J.-B.; Donnadieu, B.; Canac, Y.; Bertrand, G. Intramolecular "hydroiminiumation" of alkenes: application to the synthesis of conjugate acids of cyclic alkyl amino carbenes (CAACs). Angew. Chem., Int. Ed. 2007, 46, 2899-2902.

(3) Jazzar, R.; Dewhurst, R. D.; Bourg, J.-B.; Donnadieu, B.; Canac, Y.; Bertrand, G. Intramolecular "Hydroiminiumation and -amidiniumation" of Alkenes: A Convenient, Flexible, and Scalable Route to Cyclic Iminium and Imidazolinium Salts. J. Org. Chem. 2007, 72, 3492-3499.

(4) Lavallo, V.; Canac, Y.; Donnadieu, B.; Schoeller, W. W.; Bertrand, G. CO fixation to stable acyclic and cyclic alkyl amino carbenes: stable amino ketenes with a small HOMO-LUMO gap. Angew. Chem. Int. Ed. 2006, 45, 3488-3491.

(5) Tolentino, D. R.; Neale, S. E.; Isaac, C. J.; Macgregor, S. A.; Whittlesey, M. K.; Jazzar, R.; Bertrand, G. Reductive elimination at carbon under steric control. J. Am. Chem. Soc. 2019, 141, 9823-9826.

(6) Dolomanov, O. V.; Bourhis, L. J.; Gildea, R. J.; Howard, J. A. K.; Puschmann, H. OLEX2: A complete structure solution, refinement and analysis program. J. Appl. Cryst. 2009, 42, 339-341.

(7) Sheldrick, G. M. A short history of SHELX. Acta Crystallogr. A 2008, 64, 112-122.

(8) Frisch, M. J.; Trucks, G. W.; Schlegel, H. B.; Scuseria, G. E.; Robb, M. A.; Cheeseman, J. R.; Scalmani, G.; Barone, V.; Petersson, G. A.; Nakatsuji, H.; Li, X.; Caricato M.; Marenich A. V.; Bloino J.; Janesko, B. G.; Gomperts, R.; Mennucci B.; Hratchian, H. P.; Ortiz, J. V.; Izmaylov, A. F.; Sonnenberg, J. L.; Williams-Young, D.; Ding, F.; Lipparini, F.; Egidi, F.; Goings, J.; Peng, B.; Petrone, A.; Henderson, T.; Ranasinghe, D.; Zakrzewski, V. G.; Gao, J.; Rega, N.; Zheng, G.; Liang, W.; Hada, M.; Ehara, M.; Toyota, K.; Fukuda, R.; Hasegawa, J.; Ishida, M.; Nakajima, T.; Honda, Y.; Kitao, O.; Nakai, H.; Vreven, T.; Throssell, K.; Montgomery, J. A. Jr.; Peralta, J. E.; Ogliaro, F.; Bearpark, M. J.; Heyd, J. J.; Brothers, E. N.; Kudin, K. N.; Staroverov, V. N.; Keith, T. A.; Kobayashi, R.; Normand, J.; Raghavachari, K.; Rendell, A. P.; Burant, J. C.; Iyengar, S. S.; Tomasi, J.; Cossi, M.; Millam, J. M.; Klene, M.; Adamo, C.; Cammi, R.; Ochterski, J. W.; Martin, R. L.; Morokuma, K.; Farkas, O.; Foresman, J. B.; Fox, D. J. Gaussian 16, Revision A.03, Gaussian, Inc., Wallingford CT (2016).

(9) Hohenberg, P.; Kohn, W. Inhomogeneous electron gas. Phys. Rev. B 1964, 136, B864-B871.

(10) Kohn, W., Sham, L. J. Self-consistent equations including exchange and correlation effects. Phys. Rev. 1965, 140, A1133-A1138.

(11) Weigend, F. \& Ahlrichs, R. Balanced basis sets of split valence, triple zeta valence and quadruple zeta valence quality for $\mathrm{H}$ to Rn: Design and assessment of accuracy. Phys. Chem. Chem. Phys. 2005, 7, 3297-3305.

(12) Weigend, F. Accurate Coulomb-fitting basis sets for $\mathrm{H}$ to Rn. Phys. Chem. Chem. Phys. 2006, 8 , $1057-1065$.

(13) Grimme, S.; Ehrlich, S.; Goerigk, L. Effect of the damping function in dispersion corrected density functional theory. J. Comp. Chem. 2011, 32, 1456-1465.

(14) Grimme, S., Antony, J., Ehrlich, S. \& Krieg, H. A consistent and accurate ab initio parametrization of density functional dispersion correction (DFT-D) for the 94 elements H-Pu. J. Chem. Phys. 2010, $132,154104$.

(15) CYLview, 1.0b; Legault, C. Y. Université de Sherbrooke, 2009 (http://www.cylview.org). 